\title{
FIGURÕES

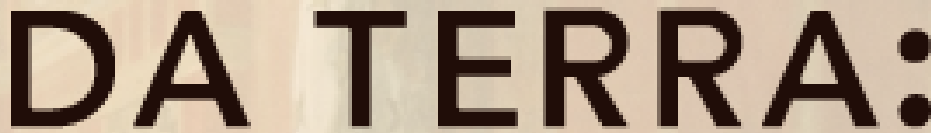

TRAJETÓRIAS E PROJETOS POLÍTICOS NO ESPÍRITO SANTO DO OITOCENTOS

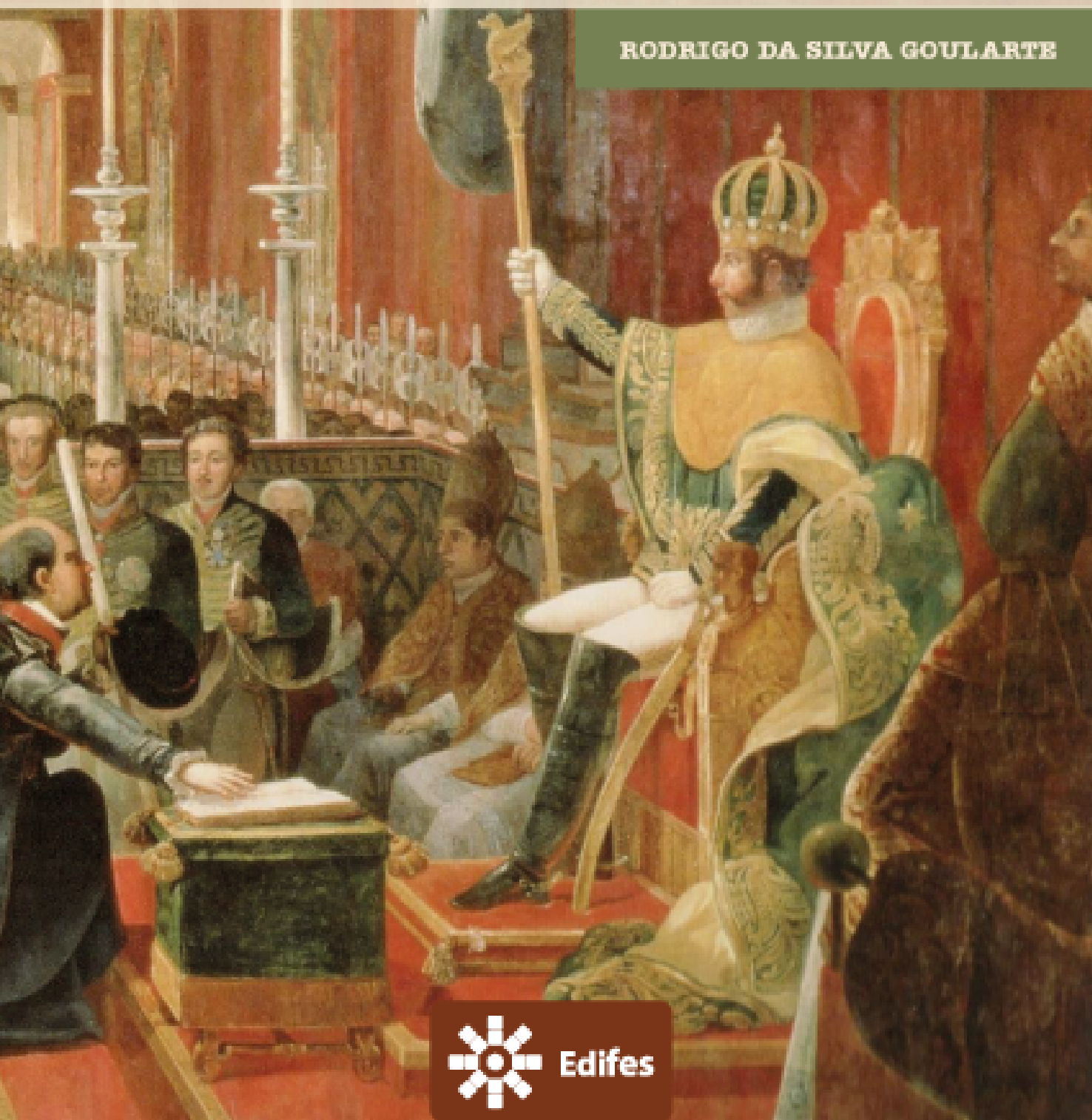




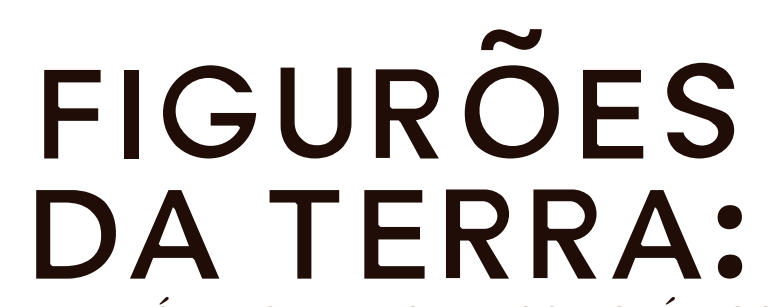

TRAJETÓRIAS E PROJETOS POLÍTICOS NO ESPÍRITO SANTO DO OITOCENTOS

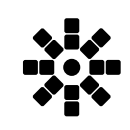

\section{Edifes}




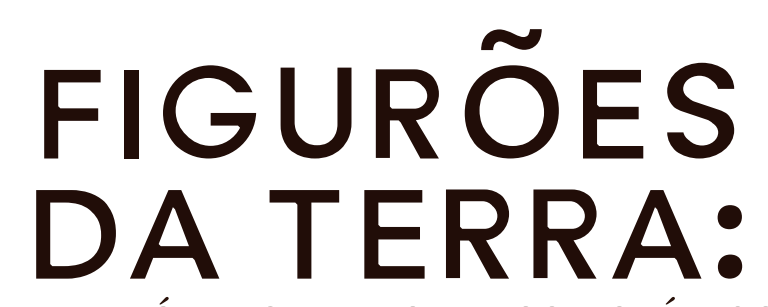

TRAJETÓRIAS E PROJETOS POLÍTICOS NO ESPÍRITO SANTO DO OITOCENTOS

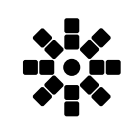

\section{Edifes}


Editora do Instituto Federal de Educação,

Ciência e Tecnologia do Espírito Santo

R. Barão de Mauá, n 30 - Jucutuquara

29040-689 - Vitória - ES

www.edifes.ifes.edu.br | editora@ifes.edu.br

Reitor: Jadir Jose Pela

Pró-Reitor de Administração e Orçamento: Lezi José Ferreira

Pró-Reitor de Desenvolvimento Institucional: Luciano de Oliveira Toledo

Pró-Reitora de Ensino: Adriana Pionttkovsky Barcellos

Pró-Reitor de Extensão: Renato Tannure Rotta de Almeida

Pró-Reitor de Pesquisa e Pós-Graduação: André Romero da Silva

Coordenador da Edifes: Nelson Martinelli Filho

Conselho Editorial

Ediu Carlos Lopes Lemos • Eliana Mara Pellerano Kuster • Diego Ramiro Araoz

Alves (Suplente) Estéfano Aparecido Vieira $\bullet$ Karin Satie Komati (Suplente) • Felipe

Zamborlini Saiter $\bullet$ Marcela Ferreira Paes (Suplente) $•$ Nelson Martinelli Filho •

Poliana Daré Zampirolli Pires • Oscar Luiz Teixeira de Rezende (Suplente) • Raoni

Schimitt Huapaya $\cdot$ Marcos Vinicius Forecchi Accioly (Suplente) $\bullet$ Ricardo Ramos

Costa $\cdot$ Ana Paula Klauck (Suplente) $\cdot$ Priscila de Souza Chisté $\bullet$ Robson Malacarne

(Suplente) $•$ Rossanna dos Santos Santana Rubim • Norma Pignaton Recla Lima

(Suplente) • Wallisson da Silva Freitas

Revisão de texto: Isabela de Souza Dantas

Projeto Gráfico, Diagramação e Capa: Assessoria de Comunicação Social do Ifes Imagem de capa: Jean-Baptiste Debret - Coroação de D. Pedro I .jpg/commons.

wikimedia.org

Dados Internacionais de Catalogação na Publicação (CID)

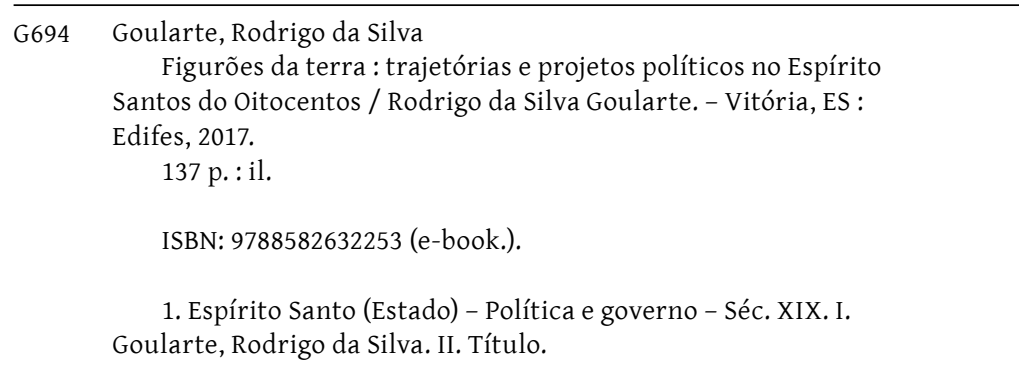

CDD $22-320.98152$

Bibliotecária Rossanna dos Santos Santana Rubim - CRB6- ES 403

@ 2017 Instituto Federal do Espírito Santo

Todos os direitos reservados.

É permitida a reprodução parcial desta obra, desde que citada a fonte.

o conteúdo dos textos é de inteira responsabilidade do autor. 


\section{Apresentação}

A obra Figurões da Terra: trajetórias e projetos políticos no Espírito Santo do Oitocentos trata do histórico da formação da elite política que conduziu a vida institucional do Espírito Santo no século XIX, o "oitocentos".

O processo da formação de um grupo político unido por laços sociais e ideias em comum nas primeiras décadas do oitocentos redundou, conforme tratam as linhas a seguir, na orquestração de um projeto que estabilizou a província do Espírito Santo diante de diferentes grupos sociais e políticos que transitavam na região.

Essa elite deixou seu legado para além do século XIX, sendo seu projeto de ordem sociopolítica mantido até os primeiros anos da república do Brasil. Em seu desenrolar, este trabalho lança luz sobre a realidade de uma das regiões do Império do Brasil (principalmente em sua consolidação), a província do Espírito Santo, para, a partir dela, promover um novo entendimento sobre a sociedade e a política brasileira nos anos da monarquia. Como muitas das práticas, conceitos e culturas políticas da república brasileira são herdeiras do período monárquico, entendê-lo é de grande importância para se pensar os fundamentos políticos da sociedade e do Estado brasileiros. 


\section{Prefácio}

Este texto é uma adaptação da dissertação apresentada no programa de pós-graduação em História da Universidade Federal do Espírito Santo (Ufes), no ano de 2008, para a obtenção do título de Mestre em História, tendo poucas alterações em relação ao escrito original, apenas no sentido de tornar o conteúdo ainda mais acessível para o público fora da academia. Nesses termos, o arcabouço teórico-metodológico, a documentação consultada, os gráficos e quadros utilizados para a comprovação da hipótese apresentada não foram mexidos. A hipótese defendida na pesquisa, em primeiro lugar, é de que nas primeiras décadas do século XIX formou-se no Espírito Santo um grupo político (elite) com unidade de pensamento e ações suficientes para estabilizar a política e a sociedade dessa província durante todo o período imperial. Essa unidade, por sua vez, advinha das proximidades sociais desses indivíduos (carreiras próximas) e por terem vivido juntos momentos fundamentais para a política e a sociedade do Espírito Santo das primeiras décadas do século XIX.

Para comprovar essa hipótese, foram consultados diferentes documentos de época (atas de reuniões da Assembleia Legislativa Provincial do Espírito Santo, por exemplo) e escritos posteriores com o objetivo de demonstrar os encontros políticos e profissionais 
entre os componentes dessa elite política. Usou-se como metodologia, portanto, a prosopografia, visando reunir os encontros desses homens para tecer uma narrativa que desse sentido à condução de um projeto para o Espírito Santo, projeto esse que visava a manutenção de uma sociedade escravista e com o domínio da política por parte de homens com alta projeção social (grandes proprietários, ocupantes de altas patentes militares, clérigos etc.).

Esta adaptação, portanto, manteve o rigor científico utilizado no momento da escrita do trabalho original, apenas ampliando a possibilidade de sua apreensão também por um público não acadêmico, objetivando servir para que os homens e mulheres do tempo presente lancem mão da História como ferramenta de compreensão do tempo presente.. 


\section{Sumário}

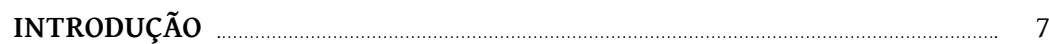

1 - DOS DONATÁRIOS AOS DEPUTADOS

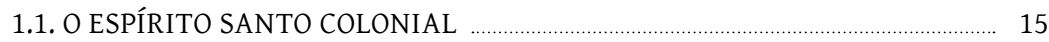

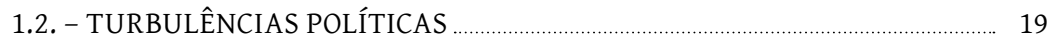

1.3. A PROVÍNCIA DE LAÇO VERDE E AMARELO _....................................... 25

1.4. O ATO E O PAÇO ...................................................................................... 33

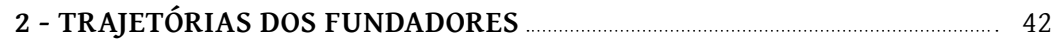

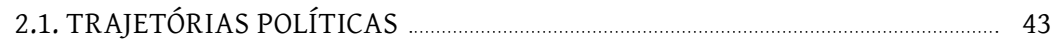

2.2. PROFISSÕES DOS DEPUTADOS …_. _ _ _ _ _ _ _ _ _ _ 52

2.2.1. Trajetórias no Império e no Espírito Santo _......................................... 59

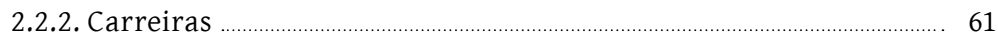

2.2.2.1. Deputados da Espada ...................................................

2.2.2.2. Deputados do Altar .......................................................... 65

2.2.2.3. Deputados da Burocracia .............................................................. 68

3 - TRAJETÓRIAS CRUZADAS _..._._. 71

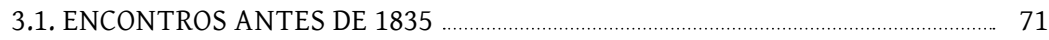

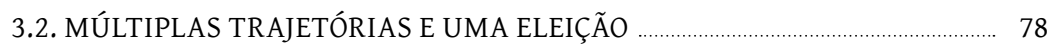

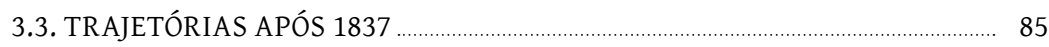

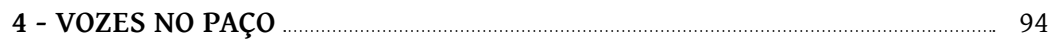

4.1. A PROVÍNCIA CLAMA _............................................................. 96

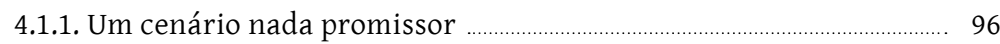

4.1.2. Os Deputados e os desafios locais .................................................... 98

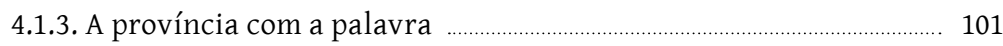

4.1.4. Uma demandante inusitada ............................................................ 103

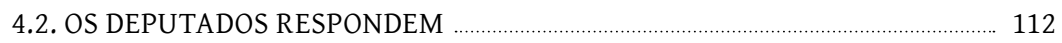

4.2.1. Os militares com a palavra ............................................................ 117

4.2.2. Os padres com a palavra ................

4.2.3. Os burocratas com a palavra ………. 122

CONCLUSÕES ...

REFERÊNCIAS _ _ _ _ 132 


\section{INTRODUÇÃO}

[...] Ano do nascimento de Nosso Senhor Jesus Cristo de mil oitocentos trinta e cinco aos trinta dias do mês de janeiro do dito ano, nesta Cidade da Vitória, Capital da Província do Espírito Santo, reunidas as pessoas eleitas para a Instalação da Assembleia Legislativa desta mesma Província na casa destinada para as sessões da mesma Assembleia, achando-se presentes onze Senhores Deputados, cujo número verificou-se suficiente para haver sessão, na forma da Constituição Art. $78^{1}$.

Em trinta de janeiro de 1835 fundou-se a Assembleia Legislativa do Espírito Santo. Graças ao Ato Adicional de 1834, cada uma das províncias do Império do Brasil pôde organizar um legislativo. Essa tarefa, entretanto, não dependia apenas de uma emenda constitucional. Nesse período, o Brasil atravessava um momento político pouco estável. O Rei havia deixado o trono em nome de seu filho, que ainda não poderia assumir, por sua menoridade. As elites nacionais estavam em seu processo de constituição, ao mesmo tempo em que construíam o Estado Imperial. No parlamento, moderados e exaltados disputavam a forma como seria conduzida essa construção. Em meados da década de 1830, uma descentralização moderada se instaurou, dando às províncias a faculdade de, pela primeira vez,

${ }^{1}$ ESTADO DO ESPÍRITO SANTO. Assembleia Legislativa. Atas. 1835-1837. 
legislarem. Todavia, como dito acima, a tarefa de constituição das assembleias provinciais não dependia apenas de uma legislação. Uma instituição é composta, construída, reconstruída e transformada por sujeitos históricos. Diante disso, no momento em que se abriu a possibilidade de criação de um parlamento em nível regional, já havia no Espírito Santo um grupo com experiência política e uma considerável coesão de interesse e pensamento. Embora essa província não fosse destacada economicamente, existia uma elite regional capaz de realizar os arranjos políticos para executar os planos de estabilização do Estado independente brasileiro. Verificou-se, inclusive, que essa elite militou localmente pela autonomia da ex-colônia portuguesa.

Os indivíduos que assumiram o comando da Assembleia Legislativa do Espírito Santo não eram personagens desconhecidos da vida pública provincial. Já participavam de importantes processos vividos na localidade, no início do XIX, como lideranças administrativas, militares e eclesiásticas, como funcionários públicos civis e intelectuais. Conheciam grande parte das conturbações políticas que sacudiram o Espírito Santo no início do oitocentos, das carências materiais presentes na localidade, enfim, até das demandas mais cotidianas da região, como as Atas da Assembleia e representações ao Governo Geral demonstram. Tratava-se de uma elite que recebera um treinamento político para enfrentar as demandas provinciais.

Sendo assim, a fundação da Assembleia Provincial, em 1835, revestiu-se de diversos significados. Pode-se afirmar que se constituiu no ponto de encontro de trajetórias e experiências individuais, assim como consistiu no elo institucional que costurou diferentes teias de relações sociais, fazendo emergir um novo cenário político no Espírito Santo, no qual ressoavam demandas de diferentes grupos sociais. A fundação da Assembleia Legislativa coroou um processo que, desde o início do oitocentos, aproximou indivíduos diferentes, mas cujos históricos individuais contavam com um longo processo de socialização política: uma aproximação de interesses, valores e práticas, como resultado de suas funções como padres, funcionários 
públicos civis e militares, ocupações que assumiam no Estado, na igreja e em irmandades.

Notou-se que tal processo não se limitava a fatores econômicos, mas também possuía elementos como filiação profissional, socialização em comunidades (como as religiosas) e parentesco familiar, além de uma participação conjunta em eventos emblemáticos para o Espírito Santo, como os episódios envolvendo a independência nacional. O objetivo foi descobrir como esses homens, em suas trajetórias profissionais, institucionais, familiares e sociais tornaram-se reconhecidos enquanto os legítimos construtores de uma nova ordem no Espírito Santo que, por sua vez, se enquadrava na realidade pós Ato Adicional de 1834.

Para serem reconhecidos desse modo, os primeiros deputados provinciais se basearam nas suas trajetórias anteriores. Para conhecê-los melhor, foram identificadas as trajetórias individuais de alguns atores que se tornaram deputados da Assembleia Provincial. Cada legislatura compunha-se de vinte deputados. O cruzamento dessas trajetórias em momentos específicos permitiu conhecer as sociabilidades entre esses personagens. Seguindo-se a tipificação de Maria Alexandre Lousada, as sociabilidades são classificadas em multifuncionais e em formal-dirigidas. Essas classificações são definidas de acordo com a variação da intensidade de três elementos: fluidez da finalidade de sua existência, grau de formalização e critério de entrada em sua organização. As multifuncionais são aquelas em que esses elementos são menos intensos. As formais, ao contrário, tem esses mesmos elementos em maior grau de intensidade $^{2}$.

A socialização desenvolvida dentro da Assembleia Legislativa do Espírito Santo pode ser entendida como uma sociabilidade formal, porque a finalidade desse agrupamento era bem específica: criar leis. A formalização era também de alto nível, já que a convivência parla-

\footnotetext{
${ }^{2}$ LOUSADA, Maria Alexandre. Espaços de sociabilidade em Lisboa. Lisboa: Dissertação de Doutorado em Geografia Humana apresentada à Faculdade de Letras da Universidade de Lisboa, 1995. p. 152.
} 
mentar obedecia a regras bem estabelecidas. Ademais, o critério de entrada nessa organização era bem restrito: apenas eram admitidos os que passassem pelo crivo das eleições. A formalidade ainda estava presente nas trajetórias individuais dos primeiros deputados da Assembleia Legislativa do Espírito Santo. As carreiras profissionais predominantes entre esses homens ligavam-se a instituições específicas como a igreja, burocracia civil e instituições militares. As carreiras políticas também estavam vinculadas ao Estado. Nesse sentido, apreende-se que a socialização entre eles, antes de 1835, de acordo com os documentos encontrados, predominava na esfera das instituições formalizadas.

Para entender as sociabilidades desenvolvidas por esses homens antes dos cargos legislativos, empreendeu-se uma profunda investigação que trouxe a tona os papéis sociais desempenhados pelos ocupantes desses cargos. Recorrendo-se a documentos contemporâneos aos personagens estudados e a relatos posteriores, escritos por memorialistas, foram encontradas pistas que revelaram os históricos individuais e o modo que essas trajetórias se cruzavam, formando uma teia de relações sociais que se estendeu até o momento de fundação da Assembleia Legislativa do Espírito Santo (1835). Como ensina a técnica da prosopografia, por meio do nome de cada personagem estudado pôde-se seguir em busca desses indivíduos em diversos momentos e contextos, revelando dimensões individuais distintas e apresentando-os em diferentes relações sociais. Esses nomes foram seguidos em diferentes escritos de época para que esses históricos individuais se construíssem e se cruzassem, formando a rede social que envolveu a primeira legislatura da Assembleia Legislativa Provincial do Espírito Santo ${ }^{3}$.

Nessa investigação, a pesquisa dos aspectos biográficos dos personagens históricos foi conectada com as biografias de outros personagens para que a teia de relações buscada tomasse forma.

\footnotetext{
${ }^{3}$ GINSBURG, C. O nome e o como. In: GINSBURG, Carlo; CASTELNUOVO, Enrico; PONI, Carlo. A micro história e outros ensaios. Lisboa: Difel, 1991. p. 173.
} 
Nesse sentido, é primordial o conhecimento, pelo menos panorâmico, da formação desses indivíduos, significando desvendar suas formações educacionais, bem como quais grupos familiares cada um deles pertencia. Na historiografia recente, há boa quantidade de estudos que privilegiam a análise da formação educacional como fator de construção dos papéis políticos. Além do clássico dos anos oitenta A construção da Ordem, de José Murilo de Carvalho ${ }^{4}$, que trata da formação da elite imperial brasileira, primeiro na universidade de Coimbra e, depois, nas faculdades do próprio Brasil, destaca-se a coletânea de artigos intitulada O Estado como vocação, organizada por Maria Emília Prado ${ }^{5}$ que analisa, entre outros temas, a importância da formação intelectual na carreira dos políticos imperiais. Como passo seguinte, adotou-se na pesquisa a análise da ocupação predominante dos deputados até o momento de instalação da Assembleia Legislativa.

Num outro momento, buscou-se a construção dos laços entre esses indivíduos, que possuíam diversos matizes. Um primeiro seria o social, termo aqui empregado no sentido de englobar as realidades de coincidências de ocupações desempenhadas pelos deputados e também de espaços sociais frequentados por esses indivíduos. Um segundo matiz seriam as relações de conotação política. Nesse caso, o termo político refere-se, em primeiro lugar, à circulação desses personagens em coincidentes espaços institucionais de poder, como o Conselho de Governo da Província. Outra conotação para esse político é a de alguns desses atores terem enfrentado juntos momentos cruciais para a conjuntura provincial. Revoltas, rebeliões, crises institucionais colocaram esses homens em situações nas quais, de maneira conjunta, tiveram que enfrentar momentos de abalo da ordem instituída, ou que, pelo menos, se instituía. Portanto, procurou-se, nessa investigação, rastrear a lenta formação de uma rede de sociabilidades que se amarrou e se consolidou institucionalmente

\footnotetext{
${ }^{4}$ CARVALHO, José Murilo de. A construção da Ordem: a elite política imperial. Brasília: Editora da Universidade de Brasília, 1981

${ }^{5}$ PRADO, Maria Emília (Org.). o Estado como vocação. Rio de Janeiro: Access, 1999.
} 
por ocasião da criação da Assembleia Legislativa do Espírito Santo.

Essa metodologia não se constitui em uma inovação dentro da historiografia. A chamada prosopografia ou biografia coletiva já é bastante utilizada em estudos contemporâneos, como fica atestado na obra Por outra história das elites, coletânea de artigos fruto de trabalhos prosopográficos de diferentes pesquisadores. 0 princípio da prosopografia não é a construção de uma biografia como algo em si mesmo, mas a busca da conexão de diferentes biografias, com a preocupação de levantar as características coincidentes de determinado grupamento em momento específico ${ }^{6}$.

Essa é a proposta deste estudo. Captar a construção ao longo do tempo de um grupo social que, no momento da fundação da Assembleia Legislativa do Espírito Santo (1835), viria a assumir o papel de elite política regional. Uma elite que, a partir da instituição recém-criada, se comunicaria oficialmente com os círculos nacionais de poder (ministérios, Assembleia Geral, presidente de província). Entender como os componentes dessa elite se projetaram até o parlamento e os laços prévios entre esses atores é alvo dessa investigação. Ou seja, compreender o caminho percorrido por esses indivíduos dentro e fora dos círculos institucionais do poder, entender a influência desses caminhos (que se cruzaram em diversos momentos) na formação política desses sujeitos e, por meio desse entendimento, fazer emergir um novo olhar sobre a política e a sociedade do Espírito Santo em princípios do século XIX.

Os resultados obtidos nessa investigação foram divididos em quatro partes. o primeiro capítulo apresentará o contexto político e social no qual a elite política do Espírito Santo se formou. Destacar-se-ão os momentos críticos enfrentados por essa elite em formação: o período da independência e conturbações sociais e políticas ocorridas no Espírito Santo. Para o melhor entendimento desse cenário, resgatar-se-á, de maneira objetiva, a trajetória política e social do Espírito Santo até os princípios do século XIX. No segundo capítulo,

\footnotetext{
${ }^{6}$ HEIZ, Flávio M. (Org.). Por outra história das elites. Rio de Janeiro: Editora FGV, 2006. p. 9.
} 
serão mostradas as ocupações dos membros dessa elite, os grupos sociais mais presentes dentro da primeira legislatura da Assembleia e as posições políticas por eles ocupadas antes de 1835. Já no capítulo terceiro, serão apresentadas as socializações desses indivíduos pelos encontros e convivência no decorrer dessas ocupações. Por fim, no quarto capítulo, serão apresentados os debates políticos dessa elite já instalada no parlamento e como essas carreiras anteriores teriam influenciado nas posições políticas dentro da nova casa de leis. 


\section{1 - DOS DONATÁRIOS AOS DEPUTADOS}

A formação da elite política do Espírito Santo teve como pano de fundo a construção simultânea do Estado Brasileiro e da elite política nacional. Nesse processo, o Ato Adicional de 1834 indubitavelmente constituiu-se em uma ruptura política no curso da jovem monarquia. No quadro das mudanças institucionais, a elite nacional teve que negociar com os poderes regionais e pouco tempo depois teve que enfrentá-los belicamente, quando das revoltas regenciais. $\mathrm{Na}$ província do Espírito Santo, por outro lado, o Ato Adicional encerrou um ciclo de construção de uma elite política, um grupo com considerável proximidade de experiências, ocupação e pensamento, processo que aconteceu em paralelo aos debates e disputas nacionais que levaram à descentralização proporcionada pelo Ato Adicional.

O Ato Adicional, por um lado, foi o ensejo para que, por um breve período, o Império vivesse uma relativa autonomia política de suas províncias. Autonomia que, por pouco, não levou ao fim da unidade nacional e significou o desfecho de uma batalha institucional que se travava desde o momento da Independência - um Império centralizado em oposição à autonomia local. Um projeto global de Estado de uma elite nacional em construção rivalizava com diversos projetos 
regionais, como ficou claro já no início do século XIX, com movimentos regionais como a Confederação do Equador em 18247. Era uma batalha que envolvia outros pares opostos, como uma monarquia absolutista em contradição com um projeto parlamentar ou as relações entre o público e o privado. A oposição entre os elementos desses pares não os impedia de em muitos momentos se coadunarem, gerando novas realidades.

Neste capítulo, portanto, objetiva-se analisar brevemente o cenário em que a elite do Espírito Santo se formou, cenário marcado pelo embate entre esses diferentes projetos político-administrativos do Império do Brasil, que teve como um dos seus pontos fundamentais a descentralização trazida pelo Ato Adicional (1834), dando poderes para as províncias. As elites regionais assumiram, por meio das Assembleias Provinciais, o controle de considerável parcela de poder. No Espírito Santo, esse processo ecoou com modulações próprias, marcadas pelas tensões centralização/descentralização.

\section{1 - O ESPÍRITO SANTO COLONIAL}

A relação de peculiaridade entre o Espírito Santo e o contexto brasileiro tem suas origens na Colônia. Desde os primórdios, as transformações regionais do Espírito Santo dependiam em grande proporção de idiossincrasias da própria Capitania. Enquanto na maior parte da Colônia a iniciativa das capitanias hereditárias mostrava-se acima das capacidades dos donatários, no Espírito Santo alguns progressos econômicos se faziam presentes na primeira metade do século XVI. Ambrósio de Meira, encarregado da arrecadação dos impostos reais, afirma que o dízimo do açúcar, até janeiro de 1546, atingira 300 arrobas, e o imposto sobre a terra foi arrendado por 43.500 réis pelo prazo de um ano (junho de 1545

\footnotetext{
${ }^{7}$ GIL, Antônio Carlos Amador. Projetos de Estado no alvorecer do Império. Vitória: Instituto Histórico e Geográfico do Espírito Santo, 2002. p. 63.
} 
a junho de 1546). Esses números colocaram o Espírito Santo numa situação de quase privilégio em comparação a praticamente todas as capitanias brasileiras. Ainda no ano de 1546, a produção açucareira da dita província chegou a 1000 arrobas, sendo que o primeiro carregamento de açúcar partiu para a metrópole no barco de Brás Teles, rico comerciante e produtor de açúcar no Espírito Santo. Quatro anos depois, essa capitania teve outro sucesso comercial. Estabeleceu-se o comércio direto entre Portugal, Vitória e Angola, sendo que nesse mesmo ano foi criada a alfândega da capitania. Esse relativo progresso, entretanto, não continuou por muito tempo. Em meados do XVI, o Espírito Santo sofreu a intensificação dos ataques indígenas, já presentes no início do século. Somavam-se a isso as discórdias entre os colonos e a irregularidade do governo. Diante disso, o comércio da Capitania paralisou-se ${ }^{8}$. Apesar dessas adversidades, percebe-se que, até meados do XVI, o Espírito Santo obteve um relativo sucesso, que destoava com a situação do resto da Colônia, imersa em profundas dificuldades, a maioria delas além das capacidades da iniciativa privada.

Deve-se destacar que foi graças à atuação de donatários que o Espírito Santo voltou a ter algum progresso, e ainda que, na fraqueza da atuação dessas autoridades, a economia dessa capitania caiu no marasmo novamente. Quando a metrópole portuguesa mudou sua política colonial para o sentido da centralização, por meio da instituição do Governo Geral, em 1549, os donatários ainda tiveram papel fundamental na organização da conjuntura local do Espírito Santo. Prova disso é que, com a posse de Vasco Fernandes Coutinho Filho (1573), houve a pacificação indígena e a promoção da agricultura. A economia do Espírito Santo floresceu novamente, com o funcionamento de seis engenhos de açúcar, além da produção de algodão e da criação de gado. Ainda no final do século dezesseis, o Espírito Santo possuía 11 mil indígenas já incorporados à civili-

${ }^{8}$ LEAL, J. E. Franklin. Economia Colonial Capixaba. Cuca: Cultura Capixaba, Vitória, n. 0, fev. 1977. 
zação. O número de colonos era de 180, sendo superior aos do Rio de Janeiro (150) e Santos (100). No início do século dezessete, o Espírito Santo dava outra mostra de seu progresso econômico, ficando em terceiro lugar na produção açucareira colonial (1500 arrobas), já tendo nesse período 500 colonos e sendo a nona maior receita entre as capitanias. Após 1630, entretanto, a Capitania sofreu com a falta de donatários, sendo governada por capitães-mores, nomeados pelo poder real, até 1674 , quando foi vendida para Francisco Gil de Araújo, que promoveu o soerguimento econômico do Espírito Santo por meio do incentivo à agricultura, vinda de novos colonos e pagamento de débitos da Capitania. Após a morte de Araújo, todavia, a Capitania entrou novamente numa fase de empobrecimento e abandono9. Percebe-se nessa trajetória que, no caso do Espírito Santo, o progresso econômico estava em grande parte ligado à atuação das autoridades locais, a despeito da centralização promovida por Portugal em meados do século dezesseis.

Entretanto, a autonomia do Espírito Santo sofreu duro golpe em inícios do século dezoito. Em 1718, a capitania foi adjudicada por sentença da Relação da Bahia à Cosme Rolim de Moura, de quem o Rei Dom João V a comprou. O Espírito Santo, portanto, passou a ser, a partir daí, capitania real. Desse ponto em diante, foi governado por capitães-mores. Ampliando a falta de autonomia da capitania, a Provisão do Conselho Ultramarino de 6 de abril de 1722 sujeitou o Espírito Santo à jurisdição do Ouvidor do Rio de Janeiro, no foro judicial. Em meados do século XVIII, no entanto, ocorreu um esforço de autonomização em nível local.

O Ouvidor Pascoal José de Melo criou a Comarca do Espírito Santo, na demarcação formada pelas vilas de São João e São Salvador de Goitacases. Já no início do século XIX, exatamente em maio de 1809, foi criada a Junta da Administração e arrecadação da Real Fazenda, abolindo-se a provedoria, ficando a Fazenda do Espírito

\footnotetext{
${ }^{9}$ LEAL, J. E. Franklin. Economia Colonial Capixaba. Cuca: Cultura Capixaba, Vitória, n. 0, fev.
} 1977. 
Santo independente da Bahia ${ }^{10}$.

Já no ano de 1817, a jurisdição do Governo do Espírito Santo era composta por seis vilas e seis povoações mais notáveis, sendo Vitória a principal vila ${ }^{11}$. No processo de transição independentista, o Espírito Santo foi governado por uma Junta de Governo Provisório, criada em dois de março de 1822, pelas Cortes de Lisboa, com funções de administração civil e política, com o governo central nomeando o comandante militar ${ }^{12}$. Essa Junta de Governo foi instituída no Espírito Santo pelo poder das Cortes e possuía componentes ligados à vertente política da não sujeição do Brasil, enquanto colônia, a Portugal.

No âmbito militar, o Espírito Santo, na transição entre os séculos XVIII e XIX, também sofreu alterações que envolveram a tensão centro-periferia. Do início do século XVIII até princípios do XIX, a capitania do Espírito Santo era vinculada militarmente à Bahia. Nesse período, portanto, as transformações nas instituições militares espírito santenses partiram da capitania vizinha ao norte. Em 1768, efetuou-se a união da Companhia de Linha do Pinto, pertencente ao Regimento de Alvim, da Bahia, à infantaria da Capitania do Espírito Santo, formando-se uma companhia de noventa infantes. Já em 1788, Dom Rodrigo José de Menezes, governador e capitão general da Bahia, determinou, em virtude da carta régia de 22 de março de 1766, que se criasse um regimento de infantaria de milícias e se lhe agregasse duas companhias de cavalaria. Essa organização foi efetuada em 1789, sendo nomeado Coronel Comandante Inácio João Monjardim, capitão-mor governador do Espírito Santo. Em 1793, por sua vez, Dom Fernando José de Portugal, Governador e Capitão General da Bahia, regulou a companhia de infantaria de

\footnotetext{
${ }^{10}$ RUBIM, Francisco Alberto. Memória estatística da Província do Espírito Santo no ano de 1817. Revista do instituto histórico e geográfico do Brasil. Disponível em: <www.estacaocapixaba. com.br>. Acesso em: 23 nov. 2004.

${ }^{11}$ RUBIM, 1817.

${ }^{12}$ OLIVEIRA, José Teixeira de. História do Estado do Espírito Santo. Rio de Janeiro: Oficinas do serviço gráfico do IBGE, 1975. p. 277.
} 
Linha com 114 praças. Já no tempo dos governadores, Antônio Pires da Silva Pontes criou o corpo de pedestres, em quatro de abril de 1800 , e formou deste o Destacamento do Porto de Souza no Distrito do Rio Doce para servir de registro e evitar surpresas do "gentio antropófago", nas palavras de Rubim. Sete anos depois, foi anexado o posto de Coronel Comandante do Regimento de Infantaria de milícias à função do Governador da Capitania ${ }^{13}$.

Em 1810, por fim, foi criado no Espírito Santo o Batalhão de Artilharia Miliciano, organizado em $1^{\circ}$ de dezembro de 1810, ficando essa capitania independente militarmente da Bahia por decreto de 13 de setembro de 1810. Com as juntas de governo provisório, houve a separação dos governos civil e militar, este entregue a um comandante de armas (Leis das Cortes de Lisboa de 29 de setembro de 1821), sendo Inácio Pereira Duarte Carneiro o primeiro Comandante das Armas ${ }^{14}$.

A autonomia da Capitania do Espírito Santo, portanto, se deu por meio de duas transformações, uma civil e outra militar. A primeira constituiu-se na criação da Junta da Administração e Arrecadação da Real Fazenda (1809). A militar, por sua vez, na criação do Batalhão de Artilharia Miliciano ${ }^{15}$. Percebe-se, por esse histórico, que o Espírito Santo teve uma trajetória marcada pela tentativa de suas autoridades locais em lidar com as determinações vindas do centro metropolitano, sendo que muitas dessas determinações não eram cabíveis à realidade local. Nesse sentido, o Espírito Santo só teve algum progresso, no período anterior à independência, graças às atitudes políticas das autoridades em nível local.

\section{2 - TURBULÊNCIAS POLÍTICAS}

A Província do Espírito Santo iniciou o século XIX com o reflexo

\footnotetext{
${ }^{13}$ RUBIM, 1817.

${ }^{14}$ NOVAES, Maria Stella de. História do Espírito Santo. Vitória: FEES, [19-]. p. 132.

${ }^{15}$ OLIVEIRA, 1975, p. 252.
} 
dos bons resultados econômicos das duas últimas décadas do século XVIII, marcadas pela exportação de produtos já tradicionais e do algodão ${ }^{16}$. No começo do novo século, essa Província passou a ser administrada por governadores e não mais por capitães-mores. 0 primeiro deles foi Antônio Pires da Silva Pontes, que procurou novas fontes econômicas para o Espírito Santo. Foi um momento de razoável progresso, que se manteve, sem grandes mudanças, até as vésperas da independência brasileira. A causa desse processo de prosperidade localiza-se no âmbito político. De acordo com Franklin Leal, foi fundamental para o Espírito Santo a presença de governantes que buscaram a implementação de mecanismos para a superação dos entraves seculares ao crescimento econômico da província ${ }^{17}$.

O relativo progresso econômico, entretanto, não era sinônimo de integral estabilidade política. Como visto no item anterior, o Espírito Santo passou o período colonial entregue às lideranças locais, fazendo muito pouco a metrópole, de maneira direta, para o crescimento econômico da Capitania. O Espírito Santo dependeu de Donatários e Capitães-Mores para alcançar algum crescimento material. Apesar de essas autoridades serem, oficialmente, representantes do poder metropolitano, quando elas se dispuseram a abraçar a administração local, promovendo alterações de acordo com as peculiaridades da Capitania, o Espírito Santo teve seus momentos de maior crescimento. Desse modo, as peculiaridades locais destacavam-se desde a Colônia e, de certo modo, no início do XIX, um clima político favorável à emancipação em relação a Portugal já se forjava na Capitania. Esse clima político foi bem expresso por meio de turbulências que aqui se fizeram presentes. Revoltas e levantes sacudiram esse momento de transição política.

Já na administração do segundo governador, Manoel Vieira de

\footnotetext{
${ }^{16}$ De acordo com relatório do governador do Espírito Santo Ignácio Monjardim ao Secretário de Estado para os negócios ultramarinos de Portugal, datada de 10 de julho de 1790, Vitória, a vila mais importante do Espírito Santo, tinha como principais produtos de exportação o algodão descaroçado, açúcar, milho e arroz. Esses produtos eram levados principalmente para o Rio de Janeiro, Bahia e Pernambuco.

${ }^{17}$ LEAL, 1977.
} 
Albuquerque Tovar (1804-1812), uma crise se instalou. O governo metropolitano ordenou o ataque contra os indígenas, o que levou a uma militarização do Espírito Santo. O governador, entretanto, se excedeu no cumprimento dessa ordenança, o que resultou em conflitos com autoridades locais, respondendo o Governador com rigor contra os que censuravam suas atitudes ${ }^{18}$. Nesse sentido, um grupo político autóctone que aqui se organizava já buscava resistir às ordenações centrais que, na maioria dos casos, contradiziam a realidade do Espírito Santo. Já nos meses de março e abril de 1820, procedeu-se uma revolta da população de Vitória contra o Governador Baltazar de Souza Botelho de Vasconcelos em virtude da rigidez da administração dessa autoridade. Os habitantes de Vitória se manifestaram por meio de protestos, desobedecendo à ordem de fechar as portas no momento do toque de recolher e pela publicação de pasquins contra o Governador ${ }^{19}$. Mais uma vez a população local expressava seu descontentamento diante de um poder central que nesse momento não contemplava as peculiaridades da realidade regional.

O momento da Independência também não transcorreu de maneira totalmente pacífica. Apesar da existência de um grupo político forte que já coadunava com a ruptura em relação ao governo central de Lisboa, alguns outros grupos se solidarizavam com a manutenção do estatuto colonial. Para tanto, o grupo político que se formava enquanto elite política do Espírito Santo hegemonizou seu projeto ligado à causa nacional do Brasil, sufocando os grupos pró-lusitanos. Um processo que deixou isso claro foi a revolta da Julianada. Com a criação das juntas de governo provisório ${ }^{20}$, em 1821, pelo governo das cortes de Lisboa, o governo militar foi separado do civil

\footnotetext{
${ }^{18}$ PENA, Misael Ferreira. História da Província do Espírito Santo. Rio de Janeiro: Tipografia de Moreira, 1878. p. 91-94.

${ }^{19}$ DAEMON, Basílio Carvalho. Província do Espírito Santo: sua descoberta, história cronológica, sinopse e estatística. Vitória: O Espírito-santense, 1879. Disponível em: <www.estacaocapixaba.com.br>. Acesso em: 18 abr. 2007.

${ }^{20}$ Composição da primeira Junta provisória do Espírito Santo: José Nunes da Silva Pires (presidente); Luiz da Silva Alves de Azambuja Suzano (secretário); José Francisco de Andrade
} 
e entregue a um comandante das armas, sendo o primeiro nomeado para esse cargo no Espírito Santo, Inácio Pereira Duarte Carneiro, futuro deputado da primeira legislatura da Assembleia do Espírito Santo. Duarte Carneiro conseguiu, no Rio de Janeiro, promover o então inspetor do Corpo de Pedestres, Julião Fernandes Leão, ao posto de Coronel. Tão logo assumiu o cargo, Julião Leão começou a exigir da Junta de Governo Provisório recém-instalada promoções para os seus comandados. Posteriormente, foi mais longe, propondo uma aliança a Duarte Carneiro para a deposição da junta. Diante da negativa de Duarte Carneiro, Julião Leão foi para o Rio de janeiro e, com o Secretário da Guerra, conseguiu ser nomeado o novo Comandante das Armas, ficando Duarte Carneiro apenas na Comissão de Estradas $^{21}$.

Parece que Julião Leão, na verdade, aproximara-se do Brigadeiro Madeira, oposicionista, na Bahia, do processo de separação entre Brasil e Portugal, o que coadunava com o papel de resistência à independência desempenhado por Julião no Espírito Santo. Leão investiu na hostilização da Junta, conseguindo a prisão de Duarte Carneiro e o desligamento do serviço da estrada do capitão Luís Bartolomeu da Silva e Oliveira. De acordo com Maria Stella de Novais, a motivação política de Julião Leão na prisão de Duarte Carneiro era conseguir a direção da estrada de Rubim e infiltrar gente de sua confiança em todo território da Província para reforço da causa portuguesa. A iniciativa pró-Portugal de Julião ficou bem clara quando, em treze de maio de 1822, determinou uma parada em homenagem a Dom João VI, em virtude do aniversário desse monarca.

A resistência a Julião Leão, entretanto, não tardou no Espírito Santo. De início, foi distribuído na vila de Vitória um impresso contra ele. Em virtude das ofensas, Julião Leão mandou prender todos os portadores do escrito. A reação institucional também não tardou. O escrivão da Junta de Governo Provisório, José da Silva

e Almeida Monjardim; José Ribeiro Pinto; Sebastião Vieira Machado.

${ }^{21}$ NOVAES, Maria Stella de. História do Espírito Santo. Vitória: FEES, [19-]. p. 132-134. 
Vieira Rios, junto com Azambuja Suzano e outros, começou a desatender as ordens de pagamento assinadas por Julião Leão quando não eram devidamente autorizadas e fiscalizadas. Este, em resposta, prendeu o escrivão para obrigá-lo a entregar as chaves do cofre. Nessa conturbação, chegou a Vitória o juiz de fora José Libâneo de Sousa para pacificar o Espírito Santo, acatando as acusações contra o Governador das Armas ${ }^{22}$.

Julião Leão, entretanto, mandou cercar a residência do juiz e ordenou que abandonasse a Vila de Vitória. Simultaneamente, Luís Bartholomeu recebeu ordem para embarcar para o Rio de Janeiro a fim de se submeter ao Conselho de Guerra. Duarte Carneiro, por sua vez, já em liberdade, junto de outros pedestres, desviou a escuna Leopard, na qual Bartholomeu embarcaria, para a ilha do Príncipe. Além disso, Duarte Carneiro mandou para a Casa do Governo grande número de homens armados. A Junta então pediu explicação a Julião Leão sobre a prisão do juiz de fora, ofensa contra a autoridade do Príncipe Regente. Julião, pressionado, ameaçou também o enviado do pedido de explicação. Diante disso, os membros da Junta do Governo Provisório dirigiram-se à residência do Juiz de Fora, onde receberam adesão da maioria da tropa que guardava a residência, permitindo a liberdade do Juiz, que foi conduzido ao palácio do governo. Julião Leão, no entanto, não deixou por menos. Organizou um pequeno exército e atacou a Junta à bala. Duarte Carneiro, todavia, com numerosos soldados da força de linha, conseguiu proteger a casa do governo com o apoio da fuzilaria de Luís Bartholomeu, "dando vivas à Santa Causa do Brasil”. Diante disso, Julião Leão quebrou a própria espada, rendeu-se e fugiu para a chácara de sua propriedade. No dia seguinte, contudo, foi preso, sendo mandado para a Corte, terminando assim o movimento conhecido como Julianada ${ }^{23}$.

Nesses termos, a Julianada foi muito importante enquanto delimitadora das forças políticas no Espírito Santo. Enquanto Julião

\footnotetext{
${ }^{22}$ NOVAES, [19-], p. 134-135.

${ }^{23}$ NOVAES, [19-], p. 136-137.
} 
Leão, seus correligionários - como o físico-mor cirurgião Joaquim Antônio Pientznauer - e seu exército representavam a causa lusitana, em aliança aos pró-portugueses baianos, a Junta de Governo Provisório e Duarte Carneiro, futuros deputados da Assembleia Provincial, denotavam sua fidelidade ao Príncipe Regente Pedro.

Daemon também faz um detalhado relato de uma crise de segurança que ameaçou as instituições do Espírito Santo, ocorrida em 1831. Nesse ano, amotinaram-se os soldados chegados da corte para reforçar e completar o Batalhão $\mathrm{n}^{\mathrm{o}}$ 12, existente há muito na província. Parte dos soldados desse batalhão uniu-se aos recém-chegados para cometer "violências" contra o próprio comandante do Batalhão Tenente Coronel Luiz Bartholomeu da Silva e Oliveira, o Major do mesmo batalhão Francisco José de Figueredo Brito e outros oficiais. O Conselho de Governo foi acionado e, depois de reunido, ordenou que logo se formasse a Guarda Municipal. A vista disso, a soldadesca principiou a percorrer armada as ruas de Vitória, dando tiros de encontro às casas e atacando o Juiz de Paz Manoel de Moraes Coutinho, futuro deputado da Assembleia Provincial do Espírito Santo. Comunicando o mesmo Juiz de Paz estes atos ao Conselho do Governo, deu ordem aos paisanos para usarem de armas e munições nas rondas que fizessem. O Vice-presidente Monjardim dirigiu-se ao quartel apenas com seu ajudante de ordens, e apaziguou a soldadesca "aconselhando-lhes sossego, ordem e obediência". Quando Monjardim comunicou ao conselho esta ocorrência, sentiu-se um tumulto na rua: eram os inferiores e soldados do mesmo batalhão que, armados, dirigiam-se ao palácio, onde se aglomeraram e gritaram. Diante disso, o Vice-presidente ameaçou-os de uma janela, mandando que, quanto antes, se retirassem para o Quartel. Desrespeitando esta ordem, vagaram pelas ruas a dar tiros, tornando a voltar ao palácio às cinco horas da tarde, subindo as escadas até a sala do Conselho à procura do Alferes Antônio Ferreira Rufino para levá-lo para o quartel, o que lhes foi concedido. Vendo o Conselho esse estado de coisas e o povo já querendo também amotinar contra a soldadesca, tomou diversas deliberações e severas providências 
para garantir a cidade ${ }^{24}$.

Esses casos demonstram que a construção das instituições e de um sistema político estabilizado não foi tarefa fácil no Espírito Santo. A elite política que se formava nesse processo teve que aprender a atuar em meio a um ambiente marcado pela instabilidade político-institucional em que diversos agrupamentos locais não aceitavam de maneira pacífica se sujeitarem às determinações vindas do governo central (no início, a metrópole; depois, o Rio de Janeiro) ou tentavam comprometer a ordem que se constituía. Apesar dessa instabilidade, os ocupantes das instituições do Espírito Santo tentaram atuar de acordo com os fatores internos e determinações externas para a construção de uma estabilidade institucional.

\section{3 - A PROVÍNCIA DE LAÇO VERDE E AMARELO}

Como se sabe, a Independência política do Brasil constituiu-se em evento peculiar em relação ao resto da América. No início do XIX, o Império Português passava por momentos decisivos. Viviam-se os resultados do retorno da importância das atividades agrárias no Brasil. Especificamente para Portugal, era uma conjuntura de turbulências políticas. A Europa estava mergulhada nas guerras napoleônicas, e, diante disso, Portugal tinha que se posicionar em uma delicada política externa entre a potência econômica da Inglaterra e a força expansionista da França. Portugal seguiu a alternativa de se aliar à Inglaterra e trasladar a coroa para o Brasil. A transferência da Monarquia Lusitana para o além-mar fez com que, na prática, o Brasil fosse perdendo seu estatuto de colônia. As medidas econômicas, como a extinção do monopólio comercial e o fim da proibição de manufaturas, geraram a convicção de que os ajustes da colônia à nova ordem político-econômica mundial poderiam ser feitos com a preservação da ordem social e do regime absolutista, em sua feição

${ }^{24}$ DAEMON, 1879. p. 285-288. 
reformista ${ }^{25}$.

A presença da Família Real em solo brasileiro também significou a montagem de um aparelho governativo no Brasil. Em 1815, o Brasil foi elevado à categoria de Reino Unido a Portugal e Algarves. Titularmente, o Brasil não era mais uma colônia. Enquanto a Família Real permanecia no Brasil, Portugal era governado por uma junta sob controle de um militar britânico que prestava contas ao Rio de Janeiro. Contra essa situação, em 1820 eclodiu um movimento revolucionário na cidade do Porto. Os revolucionários exigiam a instauração de uma assembleia nacional, as Cortes ${ }^{26}$. No Brasil, as províncias aderiram ao governo de Lisboa, ignorando a autoridade do Rio de Janeiro, que, por fim, também decidiu aderir à Lisboa.

A posição das Cortes não era unidirecional. Tentava-se, por um lado, a liberalização da vida portuguesa, buscando-se derrubar as estruturas do regime ancião. Por outro, tentava-se o restabelecimento da subordinação do Brasil. Em 1821, Dom João VI voltou para Portugal, para satisfação da "burguesia liberal e revolucionária" lusitana e de setores autonomistas do Brasil, mas para infortúnio da facção lusa residente no Rio de Janeiro e dos moderados brasileiros, temerosos da república e da fragmentação política do país. No Brasil ficou o filho do rei, Pedro, como príncipe regente. Além de obrigar a volta do rei ao solo português, as cortes constituintes baixaram uma série de atos tendentes a limitar a autonomia brasileira. As Cortes também cuidaram de cercear qualquer possibilidade de unidade brasileira em torno de um Estado independente. A política lusa, portanto, era a de tratar separadamente cada província, evitando assim uma unidade nacional. Em contrapartida, as lideranças paulistas se articularam ao lado do Senado da Câmara do Rio de Janeiro para a permanência de D. Pedro no Brasil. O temor dessas lideranças era de que o Brasil se desagregasse e que as forças locais

\footnotetext{
${ }^{25}$ SANTOS, Estilaque Ferreira dos. A monarquia no Brasil: o pensamento político da independência. Vitória: Edufes/CEG Publicações, 1999. p. 101-103.

${ }^{26}$ MONTEIRO, Hamilton de Mattos. Da independência à vitória da ordem. In: LINHARES, Maria Yedda (Org.). História Geral do Brasil. 4. ed. Rio de Janeiro, Campus, 1990. p. 126-127.
} 
tomassem posições republicanas. O grupo aglutinado no "Partido Brasileiro" previa, em princípio, a união dinástica entre Portugal e Brasil, sendo que os dois Estados estariam unidos por uma Carta comum e por uma dinastia reinante. Progressivamente, entretanto, as lideranças brasileiras perceberam a debilidade de tal proposta, em virtude da predominância de Portugal nas Cortes ${ }^{27}$. Sendo assim, as elites políticas brasileiras circundaram o regente, buscando na sua permanência a garantia da preservação da autonomia do Brasil frente a Portugal ${ }^{28}$. O embate se estendeu até setembro de 1822, quando foi proclamada a independência brasileira.

Posteriormente a esse marco, a luta continuou nos planos externo e interno. Externamente, buscava-se a consolidação da autonomia. Internamente, o combate se travava contra os projetos mais extremados de independência, como as tendências republicanas $^{29}$. Nesse momento de instalação do novo Estado, havia divergências quanto ao modo de se estabelecerem os laços de união entre as recém-instaladas províncias. As províncias do Nordeste, por exemplo, queriam um sistema político em que cada província possuísse uma relativa autonomia, como numa federação. 0 projeto que se tornou hegemônico, entretanto, foi o da delimitação de um território unificado em torno de um Estado fortemente centralizado ${ }^{30}$.

O Espírito Santo participou de maneira marcante nesse processo emancipacionista nacional. Já no dia vinte de setembro de 1821, foi eleito o representante da Província nas Cortes portuguesas. O vencedor dessa eleição foi o proprietário João Fortunato Ramos dos Santos, natural de Vitória, lente na Universidade de Coimbra em uma das cadeiras de Direito, tendo ocupado antes o cargo de Reitor. Para deputado substituto, por sua vez, foi eleito o juiz de fora José Bernardino Pereira de Almeida Batista, natural da vila de São

\footnotetext{
${ }^{27}$ MONTEIRO, 1990. p. 128-130.

${ }^{28}$ SOUZA, Iara Lis Carvalho. Pátria coroada: O Brasil como corpo político autônomo 1780-1831. São Paulo: Fundação Editora da UNESP, 1999. p. 94.

${ }^{29}$ MONTEIRO, 1990. p. 133.

${ }^{30}$ GIL, Antônio Carlos Amador. Projetos de estado no alvorecer do império. Vitória: Instituto Histórico e Geográfico do Espírito Santo, 2002. p. 9-21.
} 
Salvador de Campos, à época parte do Espírito Santo. A essa eleição estiveram presentes os eleitores Miguel Joaquim Prates, Francisco Pinto Homem de Azevedo, Julião Batista de Souza Cabral, Manoel Pinto Neto Cruz, Padre Domingos Ribeiro da Costa, Padre Marcelino Pinto Ribeiro Duarte, Vigário José Nunes da Silva Pires, Padre Manoel de Freitas Magalhães, João de Almeida Pereira e Joaquim de Oliveira Mascarenhas ${ }^{31}$.

O Espírito Santo, segundo o relato de Daemon, concordava com a ideia de emancipação nacional, por meio de sua junta de governo. Ainda de acordo com Daemon, parte dos membros da junta provisória se comunicava sobre os ideais independentistas com amigos do príncipe regente, e

[...] que adiantadas as ideias, contava D. Pedro e afinal José Bonifácio com a anuência geral desta província, e tanto assim que à Junta se dirigia reservadamente, muito antes de proclamar-se a Independência nos campos do Ipiranga, como provam documentos ${ }^{32}$.

Percebe-se, a partir do relato do referido memorialista, que o Espírito Santo já se unia, no limiar da independência, à causa emancipacionista do Brasil. Nessa Província, um grupo político já se articulava em favor de um projeto autonomista nacional. E, como visto, sufocou os que se opunham a esse projeto, como os articuladores do movimento da Julianada.

Antes de o processo independentista ter se institucionalizado, o Regente convocou uma Constituinte. Em $1^{\circ}$ de Maio de 1822 realizou-se na Igreja Matriz da Vila de Vitória a eleição de um deputado a esse conselho,

[...] sendo Presidente da Mesa Eleitoral o Juiz e Físico-mor João Antônio Pientznauer, Vereadores Inácio Pereira de Amorim, João Ribeiro das Chagas, o Quartel-mestre João Pedro da Fonseca

${ }^{31}$ DAEMON, 1879.

${ }^{32}$ DAEMON, 1879. 
Portugal, e o Presidente do Conselho Francisco Caetano Simões, em virtude do Decreto de 16 de Fevereiro deste mesmo ano, estando presentes eleitores de todas as paróquias inclusive a de São Salvador de Campos, à exceção de alguns; por eles foi eleito deputado à Constituinte o Dr. José Vieira de Matos $^{33}$.

Com a independência nacional, as câmaras das vilas capixabas manifestaram-se em apoio ao processo ${ }^{34}$, e, de modo diverso da vizinha província da Bahia, o Espírito Santo recepcionou os episódios da independência com interesse e simpatia conforme o relato de Bazílio Daemon, que informa a respeito da recepção por parte dos capixabas da notícia da Independência:

[...] o Espírito santo, onde a Junta [de Governo Provisório] e o povo de toda a província, a exceção de São Mateus e Guarapari, concordavam na idéia de proclamar-se a independência [...] e [...] Houve nesta ocasião grandes festejos, iluminação e regozijo público, havendo dias antes sido admitido como sinal de anuência à nossa emancipação política o laço verde e amarelo no braço, e tope da mesma cor no chapéu $[. . .]^{35}$.

Com a exceção de alguns grupos, portanto, a Província do Espírito Santo, apesar de sua proximidade com a Bahia, que era um dos grandes focos de resistência à separação Brasil-Portugal, militou pela independência brasileira, destacando-se da posição baiana. O Espírito Santo, no pós-independência, aderiu à nova ordem, buscando sanar suas demandas locais, antes não resolvidas pela metrópole, como demonstrado nas linhas acima. Ainda em 1822, a Portaria de 30 de Agosto do mesmo ano ordenou à Junta Provisória

[...] que não fosse aceito nem empossado em emprego algum civil, militar ou eclesiástico, indivíduo que aqui aportasse com

\footnotetext{
${ }^{33}$ DAEMON, 1879.

${ }^{34}$ DAEMON, Basílio. História, descoberta e estatística do Espírito Santo. Vitória: Tipografia do Espírito Santo, 1879. parte 5, p. 279.

${ }^{35}$ DAEMON, 1879. p. 62.
} 
despachos de Portugal, a fim de estar-se prevenido contra quaisquer surpresas ou alianças $[. . .]^{36}$.

Além disso, a portaria de $1^{\circ}$ de Setembro ordenou à Junta Provisória “[...] que não deixasse sair navio algum com tropa, mantimentos e munições de guerra com destino à Bahia, visto estar ali sublevado o General Madeira, assim como muitos outros cidadãos militares e paisanos" ${ }^{37}$. O sentimento antilusitano fora muito bem demonstrado com a resistência da Junta Provisória local contra o movimento da Julianada, com a ajuda do militar Duarte Carneiro. Como visto, elementos políticos e militares se uniram em prol do projeto antilusitano.

Continuando o processo de consolidação da Independência no Espírito Santo, no dia 4 de outubro de 1822 oficiou a ${ }^{38}$

[...] Junta Provisória ao Ministro do Império José Bonifácio de Andrade e Silva, comunicando que tendo a Câmara Municipal do Rio de Janeiro oficiado à Câmara desta província sobre a necessidade de revestir-se D. Pedro do pleno poder executivo, foi logo admitido o laço verde e marcado o dia 12 de Outubro para ser jurada a Independência, e aclamar-se o mesmo Senhor Imperador Constitucional e Defensor Perpétuo do Brasil.

O papel das câmaras foi fundamental para o revestimento de poder ao Imperador Pedro. As câmaras foram canais do reconhecimento local da autoridade real, depositando no Príncipe os seus anseios e desligando-se das Cortes de Lisboa. Essas câmaras expressaram seu desejo de ser regidas por D. Pedro, enfatizando que o poder se originava do povo, sendo que apenas por meio das câmaras esse poder seria depositado nas mãos de D. Pedro ${ }^{39}$. A Câmara de Vitória deixou isso bem explícito:

\footnotetext{
${ }^{36}$ DAEMON, 1879.

${ }^{37}$ DAEMON, 1879.

${ }^{38}$ DAEMON, 1879.

${ }^{39}$ SOUZA, Iara Lis Carvalho. Pátria coroada: O Brasil como corpo político autônomo, 17801831. São Paulo: Fundação Editora da UNESP, 1999. p. 143-149.
} 
[...] Todos somos obrigados pela Suprema Luz natural a buscar o nosso maior bem, ou nosso menor mal. Ainda quanto o Sistema atual Europeu fosse vantajoso ao Brasil; é sem controvérsia muito mais vantajoso ao mesmo Brasil o ter em si os recursos da Soberania, e do poder executivo que aplaque com prontidão os tumultos populares, reúna os partidos, proveja aos interesses particulares, e públicos, em uma palavra sirva de foco fixo donde dimanem os raios da Ordem social ${ }^{40}$.

Para a confirmação final da Independência no Espírito Santo, as Câmaras Municipais da província, em 12 de outubro de 1822, com exceção apenas de São Mateus, prestaram o juramento da Independência do Império e aclamaram Pedro como

[...] Imperador Constitucional e Defensor Perpétuo do Brasil, sendo apregoado o ato nesta capital por Januário Pereira de Souza. Houve nesta ocasião grandes festejos, iluminações e regozijo público, havendo dias antes sido admitido como sinal de anuência à nossa emancipação política o laço verde e amarelo no braço, e tope da mesma cor no chapéu $[. . .]^{41}$.

Ainda no mês de outubro, no dia 23, remeteram-se à corte, pela Junta de Governo Provisório,

[...] as cópias das atas lavradas pelas Câmaras da província ao proclamarem a Independência do Brasil e a exaltação ao trono do Senhor D. Pedro I, dando-se conhecimento dos festejos e regozijo que se desenvolveram nesse dia entre o povo $[. . .]^{42}$.

De acordo com Franklin Leal ${ }^{43}$, a Independência no Espírito Santo encerra um período de dois anos marcados pela agitação política e desatenção administrativa, principalmente por parte da Junta

\footnotetext{
${ }^{40}$ SOUZA, 1999. p. 149.

${ }^{41}$ DAEMON, 1879.

${ }^{42}$ DAEMON, 1879.

${ }^{43}$ LEAL, 1977.
} 
Provisória que governava a província e que estaria preocupada apenas em se salvar politicamente, abandonando a administração, o que teria causado a queda no comércio, agricultura e rendas. Diante desses relatos, entretanto, é difícil perceber uma junta que pensava apenas na própria salvação política. É improvável que isso tenha ocorrido diante dos relatos de um grupo político que resistiu intensamente às turbulências antiemancipacionistas, e que teve três de seus componentes como futuros deputados na Assembleia Provincial, regendo a província em seu projeto político, dentro da ordem constitucional imperial.

Com a Independência, as antigas capitanias tornaram-se províncias e passaram a ser administradas por presidentes, nomeados pelo governo central do Império recém-inaugurado. O Bacharel, ex Juiz de Fora $^{44}$ e ex Ouvidor da Capitania do Espírito Santo, Ignácio Accioli de Vasconcellos, foi o primeiro a ser nomeado presidente da Província pelo Imperador, em 25 de novembro de 1823. Sua posse somente teria lugar no ano seguinte. Dentre os diversos afazeres do governante, destacavam-se a tomada de medidas para a regulação da vida institucional do Espírito Santo, por meio da convocação das eleições para o Conselho Provincial, para deputados à Assembleia Geral e também para Senadores do Império. Os problemas estruturais da Província do Espírito Santo, entretanto, permaneceram grassando, apesar dos ares de mudança. $O$ presidente Accioli incomodava-se com a falta de recursos da Província para prover os mestres com melhores vencimentos, enquanto as péssimas condições do Hospital Militar e a má qualidade das estradas ocasionavam crescentes transtornos ${ }^{45}$.

A partir de 1824, cada província imperial passou a ter um Conselho Geral. De acordo com o artigo 73 da nova Constituição, as províncias mais populosas (Pará, Maranhão, Ceará, Pernam-

\footnotetext{
${ }^{44}$ Ignácio Accioli foi Juiz de Fora nas vilas de Ilha Grande e Parati de 1812 a 1816, e da Cidade de Cabo Frio e vila de São João de Macaé, a partir de 1817. Ocupou o cargo de Ouvidor da comarca da Capitania do Espírito Santo e, após a Independência, foi nomeado Presidente da Província capixaba.

${ }^{45}$ OLIVEIRA, 1975, p. 283.
} 
buco, Bahia, Minas Gerais, São Paulo e Rio Grande do Sul) teriam 21 membros em seus conselhos e as demais, incluindo o Espírito Santo, teriam treze membros, todos eleitos. A instalação desse órgão ainda não se constituiu na organização de um legislativo propriamente dito nas províncias, em virtude desses Conselhos Gerais não terem poder para criar leis, pois eram limitados à elaboração de propostas de leis a serem enviadas à Assembleia Geral. Essa situação mudou profundamente com a promulgação do Ato Adicional em 1834.

\section{4 - O ATO E O PAÇO}

Com o Ato Adicional, cada província do Brasil teve uma Assembleia Legislativa. A instalação desses órgãos foi o marco da organização de uma vida política mais autônoma em cada província, uma vez que a partir desse momento, as províncias passaram a ter maior área de ação independente do governo central, podendo criar leis de seus interesses, não sendo autorizadas a legislar apenas sobre impostos de importação.

o Ato Adicional constituiu o desfecho de uma luta política já presente no momento da Independência. As alternativas políticas de um império centralizado ou descentralizado, absolutista ou parlamentar desenrolaram-se até a década de 1830. Nesse momento de construção do Estado Nacional, a elite brasileira convivia com sérias desconfianças em relação a seu Imperador, herdeiro do trono lusitano. Havia o temor de que o Brasil retornasse à condição de colônia. A permanência de Dom Pedro no trono afiançava a presença e influência de um grupo português no Brasil. Apesar de a figura de Dom Pedro ter servido como mediadora da negociação entre a elite brasileira, a coroa portuguesa e a Inglaterra, negociação essa que garantiu o processo independentista, logo após a emancipação o Imperador teve alguns enfrentamentos com a elite política brasi- 
leira ${ }^{46}$.

A Assembleia Constituinte, apesar do peso político da imagem do Imperador, se opôs aos poderes da Coroa. Em 29 de julho de 1823, aprovou uma lei que isentava os atos da Constituinte de sanção imperial. Além disso, discutia um projeto de constituição que previa um forte controle do parlamento sobre o soberano e uma relativa autonomia das províncias. Diante disso, o Imperador fechou a Assembleia em 25 de março de 1824 e jurou uma constituição redigida a mando próprio, em que o monarca era considerado inviolável e sagrado, não podendo ser responsabilizado por seus atos. Essa Constituição também estabelecia uma Câmara eleita, um Senado vitalício escolhido pelo Imperador, e uma grande centralização das províncias em torno do Rio de Janeiro. Além disso, o Imperador dispunha do instrumento do poder moderador, que permitia ao monarca indicar gabinetes sem a devida aprovação parlamentar ${ }^{47}$.

Os conflitos entre coroa e parlamento continuaram em 1826. Em março desse ano, o Imperador abriu os trabalhos da primeira Assembleia Geral Legislativa. Dessa data até 1831, seguiu-se uma progressiva disputa entre a Câmara dos Deputados e o Monarca ${ }^{48}$. É preciso notar a particularidade desse período histórico porque a hostilidade entre o Parlamento e o Imperador produziu um liberalismo construído como instrumento de oposição, fato que gerou conceitos legais muito complexos. Como observa Carneiro da Cunha 49 , "a Câmara venceu a sua dupla e contraditória tarefa: legislar para um governo rebelde, detentor do poder, mas rebelde, e aprender a combatê-lo incansavelmente, a discipliná-lo, enfim, pela expulsão". Os liberais deram vida à sua condição oposicionista por meio de uma elevada quantidade de leis, destacando-se a criação do Tribunal de Justiça, da Caixa de Amortização, dos cursos jurídicos,

\footnotetext{
${ }^{46}$ CARVALHO, José Murilo de. Cidadania no Brasil: o longo caminho. 6. ed. Rio de Janeiro: Civilização Brasileira, 2004. p. 26.

${ }^{47}$ MONTEIRO, 1990, p. 135-137.

${ }^{48}$ MONTEIRO, 1990, p. 135.

${ }^{49}$ CUNHA, Manuela Carneiro. Antropologia do Brasil: Mito, história, etnicidade. São Paulo, 1985. p. 399.
} 
da definição da responsabilidade dos Ministros e Conselheiros de Estado, o estabelecimento do Juiz de Paz e do Júri e, finalmente, a redação do Código Criminal. O desfecho dessa luta foi a abdicação de Dom Pedro I em sete de abril, significando a afirmação, conforme Gabriela Nunes Ferreira, da Nacionalidade e dos princípios liberais contra o Absolutismo e os interesses portugueses identificados com Dom Pedro $\mathrm{I}^{50}$.

Conforme relata José Murilo de Carvalho, a preocupação central da elite política brasileira foi colocar em funcionamento a monarquia representativa de modo a eliminar os vestígios de absolutismo presentes nos atos do Imperador e de seus ministros. Adotaram-se diversas medidas descentralizadoras, para que se pudesse retirar o máximo de poder do governo imperial, transferindo-o para os poderes provinciais. $\mathrm{Na}$ verdade, essa reforma iniciou-se ainda durante o governo de D. Pedro I, mas foi consolidada durante a Regência. As propostas de reforma opuseram liberais exaltados a liberais moderados. Os Moderados defendiam um parlamentarismo à inglesa e os Exaltados um federalismo radical, que, segundo Joaquim Nabuco, ensejou vários movimentos separatistas eclodidos de norte a sul do país, ameaçando a unidade territorial brasileira ${ }^{51}$. Esse federalismo radical significava a criação de assembleias legislativas provinciais e a eleição dos presidentes das províncias, o que seria um grande esforço de descentralização ${ }^{52}$.

Já no ano da Abdicação, foram dados passos em direção à descentralização. A principal resolução foi a criação da Guarda Nacional, uma milícia armada dirigida pelos grandes proprietários. Em 29 de novembro de 1832, foi criado o Código do Processo Criminal, dando amplos poderes ao Juiz de Paz, eleito diretamente sob a influência

\footnotetext{
${ }^{50}$ FERREIRA, Gabriela Nunes. Centralização e Descentralização no Império: O Debate entre Tavares Bastos e visconde do Uruguai. São Paulo: Editora 34, 1999. p. 26.

${ }^{51}$ CARVALHO, 1998, p. 164-165.

${ }^{52}$ BASILE, Marcelo. Projetos de Brasil e construção nacional na imprensa fluminense. In: NEVES, Lúcia Maria Bastos P.; MOREL, Marco; FERREIRA, Tânia Maria Bessone da C. (Org.). História e imprensa: representações culturais e práticas de poder. Rio de Janeiro: Faperj, 2006. p. 77-78.
} 
dos senhores locais ${ }^{53}$. Na Câmara, venceram os exaltados, aprovando um projeto de reforma constitucional que estabelecia uma monarquia federativa com assembleias provinciais bicamerais. No entanto, esse projeto de lei não foi aprovado pelo Senado, vencendo, por fim, os Moderados, defensores de um ideal de sistema político localizado num meio termo entre democracia e absolutismo, buscando limitar os poderes dos governantes (por meio da divisão de poderes e instituições representativas), mas com a rejeição de qualquer preceito social de igualitarismo ou universalização da política ${ }^{54}$. De acordo com Gabriela Nunes Ferreira ${ }^{55}$ esse ímpeto reformista estava relacionado a uma fase em que faltava à elite dirigente uma ideia clara sobre o tipo de organização política mais adequada a seus interesses, sendo que o autogoverno das forças territoriais aparecia como solução para a estruturação do poder. Nesse sentido, a década de 1830 foi um dos momentos mais interessantes no histórico das relações centralizadoras e descentralizadoras no Brasil. A ideia da unidade política em torno de uma monarquia forte, preconizada na Independência, agora era desafiada de maneira contundente por setores da própria elite, demonstrando que o posicionamento político de um grupo social não é monolítico ao longo do tempo.

Dois anos mais tarde, aprovou-se o Ato Adicional. Essa lei acrescentada à Constituição transformava a regência trina em una (o regente seria escolhido pelo corpo de cidadãos do país e não mais pela Assembleia Nacional) e extinguia o Conselho de Estado. Mas a grande mudança política trazida por essa legislação constituiu-se no fato de as províncias deixarem de ser simples unidades administrativas para tornarem-se unidades políticas. Os conselhos provinciais foram extintos e substituídos pelas assembleias legislativas, com amplo espectro de poderes, podendo legislar sobre impostos, receita e despesa provincial, empregos municipais e provinciais, polícia e economia municipal. A assembleia legislativa também

\footnotetext{
${ }^{53}$ MONTEIRO, 1990. p. 137.

${ }^{54}$ BASILE, 2006. p. 61.

${ }^{55}$ FERREIRA, 1999, p. 27.
} 
escolhia entre os seus pares o vice-presidente da província, contrabalançando a influência do Governo Central que nomeava o presidente $^{56}$. Enfim, o legislativo provincial nasceu poderoso, concentrando poderes antes dos municípios e depois do governo central, fortalecimento político que perdurou até o final da década de 1830, quando o regresso conservador trouxe uma nova onda centralizadora que faria as assembleias perderem muito de seu poder. 0 Ato Adicional diferenciava as províncias quanto ao número de componentes da assembleia. Segundo o Artigo $2^{\circ}$ do Ato, as províncias de Pernambuco, Bahia, Rio de Janeiro, Minas Gerais e São Paulo poderiam possuir trinta e seis deputados cada uma em suas assembleias; Pará, Maranhão, Ceará, Paraíba, Alagoas e Rio Grande do Sul poderiam ter vinte e oito deputados cada uma e as demais províncias poderiam ter vinte deputados cada uma, no último grupo se incluindo o Espírito Santo ${ }^{57}$.

A escolha dos membros desse novo órgão seguia o padrão já determinado pela Constituição, que acontecia em eleições primárias, nas quais homens livres, com renda mínima de cem mil réis anuais, escolheriam os eleitores da província. Tais eleitores deveriam possuir renda não inferior a duzentos mil réis anuais e escolheriam os membros da assembleia legislativa provincial. Cada legislatura duraria dois anos, exceto a que começava em 1835, que duraria até 1837, e a assembleia funcionaria dois meses a cada $a n 0^{58}$.

As reformas regenciais descentralizadoras liberaram forças regionais até então contidas pelo centralismo imperial ${ }^{59}$, eclodindo revoltas provinciais de norte a sul do país. Farroupilha (Rio Grande do Sul), Balaiada (Maranhão), Sabinada (Bahia) ameaçaram fragmentar a unidade política brasileira, um dos principais pontos de

\footnotetext{
${ }^{56}$ FERREIRA, 1999. p. 28-29.

${ }^{57}$ Brasil. Lei $n^{\circ} 16$ de 12 de agosto de 1834. Faz algumas adições à Constituição Política do Império, nos termos da Lei de 12 de outubro de 1832. Disponível em: <www.irdeb.ba.gov.br>. Acesso em: 23 ago. 2006.

${ }^{58}$ BICHARA, Terezinha Tristão. História do poder legislativo do Espírito Santo, 1835-1889. Vitória: Leoprint, 1984. p. 42.

${ }^{59}$ MONTEIRO, 1990, p. 138.
} 
convergência da elite nacional. Nesse momento de maior autonomia provincial, muitas das elites regionais do país não processaram de maneira pacífica as demandas locais e optaram pela forma violenta (revoltas armadas) para a resolução dessas questões. Diante desse quadro, o Espírito Santo constituiu-se como realidade peculiar, em virtude de utilizar outro canal para expressar suas demandas políticas, constituindo-se esse canal na articulação da elite local por meio da assembleia legislativa e não de um movimento de revolta contra o Governo Geral.

No Espírito Santo, o Ato Adicional foi publicado em todos os municípios, havendo “[...] por essa ocasião grandes festejos nesta capital [Vitória] e outros lugares [...]"60, sendo que o Padre João Clímaco de Alvarenga Rangel, futuro primeiro presidente da Assembleia Provincial “[...] no Ato Adicional tomara grande parte escrevendo um hino no qual falava com entusiasmo que lhe ia n'alma [...] das províncias[...]"61. Em decorrência do Ato Adicional, o Espírito Santo poderia ter sua própria assembleia legislativa.

A fundação da assembleia legislativa significou um momento determinante na vida política do Espírito Santo, em virtude de criar um espaço permanente (que se manteve em funcionamento até 1889 , com a proclamação da república), em que a elite política capixaba se concentrava para processar as demandas da província, e certamente para forjar e manter mecanismos para a perpetuação de uma ordem social marcada pela escravidão e limitação do acesso ao poder político. Em seus 54 anos de funcionamento, a Assembleia Provincial constituiu-se num grupo de interesses ${ }^{62}$ em que os atores políticos da elite provincial sistematizavam suas demandas e as transformavam em práticas políticas por meio da criação de legislações ou do envio de demandas ao governo central. o paço legisla-

\footnotetext{
${ }^{60}$ DAEMON, 1879. parte 5, p. 302.

${ }^{61}$ PEREIRA, Amâncio. Almanak do Estado do Espírito Santo. Vitória: A. Moreira Dantas, 1899. p. 27.

${ }^{62}$ ALMOND, Gabriel A.; POWELL, G. Bingham. Uma teoria política comparada. Rio de Janeiro: Zahar Editores, 1972. p. 120.
} 
tivo provincial, portanto, foi o lócus que no Espírito Santo permitiu a circulação e o encontro de atores sociais com históricos de vida particulares, mas que tiveram de negociar dentro do jogo político-institucional nacional para poder fazer valer seus interesses e manter em andamento a ordem político-econômica da sociedade brasileira imperial.

Como dizia o Ato Adicional, em 1834 o Espírito Santo escolheu, de maneira censitária, os vinte deputados para ocuparem a Assembleia Legislativa Provincial. A tabela abaixo informa o nome dos primeiros ocupantes desse lócus de poder.

\section{TABELA 1 - PRIMEIRA LEGISLATURA DA ASSEMBLEIA LEGISLATIVA PROVINCIAL DO}

ESPÍRITO SANTO (1835-1837)

DEPUTADOS
Luiz da Silva Alves de Azambuja Suzano
Francisco Pinto Homem de Azevedo
João Luiz da Fraga Loureiro
Manoel da Silva Maya
José de Barros Pimentel
Manoel Moraes Coutinho
Dionísyo Álvaro Rozendo
Manoel d’ Assunção Pereira
José Francisco de Andrade e Almeida Monjardim
Ignácio Félis de Alvarenga Sales
João Clímaco de Alvarenga Rangel
Francisco Ribeiro Pinto
Manoel Pinto Rangel e Silva
Joaquim da Silva Caldas
Manoel da Siqueira e Sá Júnior
Miguel Rodrigues Batalha
Sebastião Vieira Machado
Ayres Vieira de Albuquerque Tovar
João Nepomuceno Gomes Bittencourt
Inácio Pereira Duarte Carneiro


A primeira reunião (em trinta de janeiro de 1835) concentrou-se na análise da legitimidade dos diplomas dos deputados, ou seja, se os eleitos preenchiam os pré-requisitos estabelecidos pela Constituição para ocupar o lugar de deputado provincial. Para tanto, foram escolhidas por escrutínio secreto duas comissões, de três componentes cada. Uma foi encarregada de analisar a legitimidade dos diplomas dos demais deputados e a outra de examinar a legitimidade dos diplomas dos componentes da primeira comissão. Para dirigir os trabalhos foram escolhidos provisoriamente, por aclamação, para Presidente da Assembleia, o Padre João Clímaco de Alvarenga Rangel e, para Secretário, o Reverendo Ignácio Félis de Alvarenga Sales.

Na segunda reunião, também de caráter preparatório, ocorrida em trinta e um de janeiro de 1835 , os deputados saíram em conjunto da sede onde estavam reunidos, dirigiram-se à Igreja Matriz e nesse lugar prestaram juramento. Na sessão de primeiro de fevereiro do mesmo ano, por sua vez, houve a instalação da Assembleia Legislativa Provincial. Nessa reunião, esteve presente o Presidente da Província do Espírito Santo, o Capitão José Pires da Silva Pontes, que leu o relatório dos negócios públicos da Província, de acordo com o Artigo $8^{\circ}$ do Ato Adicional. Em sequência, verificou-se a eleição da mesa diretora da Assembleia, sendo eleitos Presidente João Clímaco de Alvarenga Rangel, com doze votos; e Vice-Presidente Manoel Pereira D’Assunção, com onze votos. Houve empate de quatorze votos entre João Luiz da Fraga Loureiro e Dionízio Álvaro Rozendo durante a eleição do Secretário da mesa. O impasse foi decidido por sorteio, pendendo a sorte para João Luiz da Fraga Loureiro como Primeiro Secretário e Dionízio Álvaro Rozendo como Segundo Secretário.

Grande parte dos indivíduos que compuseram a primeira legislatura desse parlamento não era novata na vida pública do Espírito Santo. Anteriormente, ocuparam cargos administrativos e militares na Província, como se apresentará nos próximos capítulos. Além disso, grande parte dos parlamentares eram "homens das letras", ou seja, possuíam formação superior e destaque em seus estudos, publicando obras como poemas e artigos. 
Sendo assim, paralelamente ao processo de construção do Estado e da elite nacionais, o Espírito Santo vivia na primeira metade do século XIX a constituição de sua elite política local, uma elite que teve expressão institucional de suas demandas na Assembleia Legislativa Provincial. Ou seja, todo processo de institucionalização do Estado brasileiro, bem como da formação de sua elite política dirigente retumbou na província do Espírito Santo, mas com modulações próprias, dando oportunidade a um grupo dirigente local de amalgamar sua posição de poder. Desse modo, pretende-se reconstruir a trajetória de parte dessas lideranças enfocando seu espaço político-institucional mais basilar, que se deu na Assembleia Legislativa Provincial.

No novo desenho do Estado brasileiro recém-criado, os líderes políticos capixabas assumiram o parlamento como a oportunidade e o bastião para sanar as demandas políticas e sociais presentes há muito tempo no Espírito Santo. 


\section{2 - TRAJETÓRIAS DOS FUNDADORES}

Depois de intensos momentos de disputas políticas com participação das elites regional e nacional, e com diferentes projetos políticos envolvendo centralização e descentralização político-administrativa, as elites nacionais dão o importante passo de promoverem o fortalecimento político em nível provincial. Fazem surgir diversas assembleias em todo o país em meados da década de 1830, promovendo, em seguida, imprevistamente, a explosão de diversas revoltas. A criação dessas assembleias provinciais dependeu não apenas do processo de emancipação nacional e consequente organização do Estado, mas também da preexistência de elites regionais capazes de levar em frente uma organização político-institucional democrática segundo os parâmetros da época. O caso do Espírito Santo revela a construção regional de uma elite que assumirá postos de mando na década de 1830, num contexto de fortalecimento da política regional.

Os parlamentares eleitos pelos colégios eleitorais da província do Espírito Santo, em dezembro de 1834 (que em princípio ficariam no poder por mais três anos) eram em sua maioria nativos dessa província. Já haviam se encontrado anteriormente em outros ambientes, institucionais ou não. Possuíam trajetórias pessoais distintas, mas que se cruzaram em alguns momentos e possuíam 
similaridade em alguns pontos. O objetivo deste capítulo é fazer um panorama da formação social da primeira legislatura da Assembleia Provincial do Espírito Santo, tentando levantar a relação entre a atuação política desses parlamentares e seu grau de coesão social na organização do parlamento capixaba.

\section{1 - TRAJETÓRIAS POLÍTICAS}

Na sessão de instalação da Assembleia Provincial do Espírito Santo, em trinta de janeiro de 1835, onze deputados (o Ato Adicional previa 20 para o Espírito Santo, mas faltaram nove na primeira reunião) reuniram-se para darem início aos trabalhos do novo parlamento. Pela primeira vez, no Espírito Santo, um grupo dirigente alcançava autonomia política regional com força política para exigir atenção aos seus próprios projetos de desenvolvimento. Grande parte desses homens não era estreante no exercício do poder. João Clímaco de Alvarenga Rangel, primeiro Presidente da Assembleia Provincial do Espírito Santo, na década de 1830, ocupou a função político-institucional de Deputado na Assembleia Geral, mas sua trajetória anterior revela que seus projetos autonomistas dotavam de muito antes de 1835.

Levantou-se que onze deputados se envolveram com a política institucional em momentos anteriores a 1835. Antes do Ato Adicional, havia algumas possibilidades para ocupação de cargos político-institucionais disponíveis para os indivíduos de destaque na província. Vereador da câmara municipal, membro do conselho geral de província, participação no conselho de governo de província ou uma deputação na assembleia geral foram as principais funções assumidas por esses dirigentes. A tabela abaixo apresenta a distribuição dessas ocupações entre os deputados: 
TABELA 2 - DISTRIBUIÇÃO DOS CARGOS INSTITUCIONAIS ANTERIORES A 1835

\begin{tabular}{|c|c|c|c|c|}
\hline DEPUTADOS & Vereador & $\begin{array}{l}\text { Conselho } \\
\text { Geral }\end{array}$ & $\begin{array}{l}\text { Assembleia } \\
\text { Geral }\end{array}$ & $\begin{array}{l}\text { Junta } \\
\text { Provisória/ } \\
\text { Conselho de } \\
\text { Governo }\end{array}$ \\
\hline $\begin{array}{l}\text { Luiz da Silva Alves de Azambuja } \\
\text { Suzano }\end{array}$ & - & - & - & $x$ \\
\hline $\begin{array}{l}\text { Francisco Pinto Homem de } \\
\text { Azevedo }\end{array}$ & $x$ & - & - & $x$ \\
\hline João Luiz da Fraga Loureiro & - & - & - & - \\
\hline Manoel da Silva Maya & $x$ & $x$ & - & - \\
\hline José de Barros Pimentel & - & - & - & - \\
\hline Manoel Moraes Coutinho & - & - & - & $x$ \\
\hline Dionísyo Álvaro Rozendo & $x$ & - & - & - \\
\hline Manoel d' Assunção Pereira & - & - & - & - \\
\hline $\begin{array}{l}\text { José Francisco de A. e Almeida } \\
\text { Monjardim }\end{array}$ & $x$ & $x$ & - & $x$ \\
\hline Ignácio Félis de Alvarenga Sales & - & $x$ & - & $x$ \\
\hline João Clímaco de Alvarenga Rangel & - & - & $\mathrm{x}$ & - \\
\hline Francisco Ribeiro Pinto & - & - & - & - \\
\hline Manoel Pinto Rangel e Silva & $\mathrm{x}$ & - & - & - \\
\hline Joaquim da Silva Caldas & - & - & - & - \\
\hline Manoel da Siqueira e Sá Júnior & $\mathrm{x}$ & $x$ & - & - \\
\hline Miguel Rodrigues Batalha & - & - & - & - \\
\hline Sebastião Vieira Machado & $x$ & - & - & $x$ \\
\hline Ayres Vieira de Albuquerque Tovar & - & - & - & - \\
\hline $\begin{array}{l}\text { João Nepomuceno Gomes } \\
\text { Bittencourt }\end{array}$ & - & - & - & - \\
\hline Inácio Pereira Duarte Carneiro & - & - & - & - \\
\hline
\end{tabular}

De acordo com essa tabela, antes de 1835 sete deputados foram vereadores, quatro foram membros do Conselho Geral (criado em 1824, com poderes de criar projetos de lei), um foi Deputado Geral e seis foram ocupantes de postos da administração da província 
ou no Conselho de Governo (órgão que acompanhava o presidente de província na administração; e na ausência deste, um dos seus membros ocupava provisoriamente a presidência) ou na Junta de Governo Provisório, que governou a província na transição independentista. Há o destaque para João Clímaco de Alvarenga Rangel, único entre os arrolados que conseguiu uma deputação na Assembleia Geral antes de 1835.

Percebe-se também que alguns futuros deputados estiveram em mais de uma dessas organizações. Três acumularam em suas trajetórias políticas os cargos de vereadores e membros do Conselho Geral, sendo eles Manoel da Silva Maya, José Francisco de Andrade e Almeida Monjardim e Manoel da Siqueira e Sá Júnior. Três foram vereadores e estiveram em Conselho Administrativo da Província: Francisco Pinto Homem de Azevedo, Sebastião Vieira Machado e José Francisco de Andrade e Almeida Monjardim. Dois também estiveram no Conselho Geral e no Conselho de Governo, Ignácio Félis de Alvarenga Sales e, mais uma vez, Monjardim.

No momento estudado, é complexo fazer uma separação clara entre quais ocupações eram administrativas e quais eram legislativas. Juridicamente, o Espírito Santo só teve um parlamento em 1835. O Conselho Geral, criado em 1824, não tinha poder para materializar em leis as propostas que fazia. Entretanto, esse órgão podia apresentar projetos de lei que seriam encaminhados para a Assembleia Geral. Ou seja, apesar de não poderem legislar até a finalização da norma jurídica, isso não significava que o Conselho Geral era vazio de debate político.

As câmaras de vereadores, de acordo com a Carta Magna de 1824, seriam eleitas e presididas pelo vereador mais votado. A lei de organização municipal de $1^{\circ}$ de outubro de 1828 , entretanto, cerceou a autonomia das câmaras legislativas, colocando-as sob a dependência dos conselhos provinciais, dos presidentes de província e do Governo Geral ${ }^{63}$.

${ }^{63}$ FERREIRA, Gabriela Nunes. Centralização e Descentralização no Império: O Debate entre 
As câmaras brasileiras já possuíam em seu histórico uma trajetória em que as funções legislativas não eram uma constante. No Império Português elas funcionavam como órgãos simultaneamente administrativos e judiciários, debatendo e arbitrando em nível local o poder político institucional. Também se correspondiam com o Conselho Ultramarino e com o próprio rei português. As câmaras exerciam um poder local, correspondente à justiça, administração, fisco e aparelho militar. Funcionavam como mediadoras entre a localidade e o monarca, comunicando-se por meio de petições e representações. A partir delas, organizava-se a hierarquia local, designando quem podia ou não participar da administração e do uso da palavra. No Brasil, essa instituição possuía mais autonomia que suas correspondentes portuguesas. As câmaras eram um lugar da elite local, do exercício de poder. No momento de independência as câmaras brasileiras declararam seu apoio a D. Pedro. As regiões Sudeste-Sul se alinharam mais rapidamente ao príncipe, enquanto no Norte-Nordeste parte das províncias se reportava à Corte ou matizava sua autonomia entre o príncipe e as Cortes portuguesas ${ }^{64}$.

No caso do Espírito Santo, as câmaras também manifestaram apoio a D. Pedro. De acordo com o testemunho de Luiz da Fraga Loureiro, Presidente da Câmara de Vitória em 1823, o Secretário do Governo Provisório do Espírito Santo, Luiz da Silva Alves de Azambuja Suzano, propôs que D. Pedro fosse aclamado Imperador, como acontecera na Corte do Rio de Janeiro. Diante disso, a Câmara foi para a Matriz para, "junto com as demais corporações", fazer a aclamação ${ }^{65}$.

Com as funções de organização da vida social (âmbitos militar, fiscal, judiciário) as câmaras do Espírito Santo, apesar de limitadas quanto ao poder de legislar, principalmente após 1828, construíram

Tavares Bastos e visconde do Uruguai. São Paulo: Editora 34, 1999. p. 24.

${ }^{64}$ SOUZA, Iara Lis Carvalho. Pátria coroada: O Brasil como corpo político autônomo, 17801831. São Paulo: Fundação Editora da UNESP, 1999. p. 143-146.

${ }^{65}$ BIBLIOTECA NACIONAL. Documento C 694, 11. 1823. Luiz da Silva Alves de Azambuja Suzano, Petição. 1823. 
em seu interior o debate político, pois as decisões eram tomadas por um agente coletivo formado pelos vereadores. Nesse sentido, apesar de o Espírito Santo não possuir à época um parlamento em sentido estrito, com capacidade de promulgar leis, isso não significava que os futuros componentes da Assembleia Legislativa não tiveram contato com o debate político e com a realidade de se tomar decisões de maneira conjunta. Ao contrário, como já se relatou, a Câmara de Vitória, por exemplo, sediou, em 1822, um extenso debate, solicitando que D. Pedro dirigisse a formação do Estado brasileiro autônomo, e em 1823, quando os vereadores realizaram um ato de apoio ao Príncipe na Praça da Matriz. Enfim, a elite local capixaba militava e discutia nesta região um projeto de autonomia para o Brasil, que coincidia com aquele projetado no Rio de Janeiro - uma monarquia constitucional.

A ocupação de postos administrativos no antigo Império Português pela elite política do Espírito Santo, certamente, foi fundamental para a capacitação dos futuros deputados. Na primeira legislatura, os Deputados no Espírito Santo tiveram que reorganizar a administração provincial para atender ao novo contexto político, marcado pela divisão do poder entre a Assembleia Legislativa Provincial e o governo do presidente de província.

A elite política, no entanto, não podia agir diretamente na execução da administração, pois essa era uma função do presidente. Em relação à administração da província, a Assembleia buscava intervir na distribuição dos funcionários, disposição dos documentos e organização das repartições do governo. Na ata de três de fevereiro de 1835, a Assembleia Legislativa decidiu mandar ofício ao governo provincial pedindo o envio dos documentos do extinto Conselho Provincial ${ }^{66}$. Outro exemplo da preocupação do legislativo provincial com a condução dos negócios locais foi consubstanciado na representação de treze de dezembro de 1837, contra o Presidente José Thomaz Nabuco de Araújo, dirigida à própria Majestade Impe-

${ }^{66}$ ESTADO DO ESPÍRITO SANTO. Assembleia Legislativa. Atas. 1835-1837. 
rial, em que esse presidente era criticado por sua "[...] negligência, inaptidão espantosa, que tem tornado como em abandono toda a marcha da pública administração [...]", tendo apresentado para a Assembleia um relatório "[...] falto de franqueza e de informações positivas e exatas dos negócios essenciais da província [...]”. Sendo assim, a

[...] Assembleia embaraçada e carecida de informações para poder resolver sobre a administração que se há de seguir, debalde tem recorrido a freqüentes interpelações por pedidos das comissões de seu seio porque às queixas de abusos do poder responde o presidente que não cumpre dar conta se não ao supremo conselho de justiça [...] e [...] sobre infrações de Leis expressas diz que não sabe que haja Lei, nem a do seu regimento, ou que julgou não devê-las cumprir ${ }^{67}$;

Dentre os presidentes da Província capixaba da primeira metade do XIX, Thomaz Nabuco foi o mais diretamente atacado. Não é meta desse trabalho a investigação dos objetivos políticos da Assembleia em reclamar tanto ao Governo Central desse funcionário. Muito menos julgar as capacidades administrativas ou a lisura desse estadista imperial, como o chamou seu filho, Joaquim Nabuco. Mas pode-se afirmar que havia dentro da Assembleia do Espírito Santo homens com experiência política suficiente para fazer esse julgamento, pois onze deputados da primeira legislatura possuíam longa experiência com a política institucional, e seis deles ocuparam funções na administração provincial. É válido destacar o caso de José Francisco de Andrade e Almeida Monjardim. Esse político, em 1821, ocupava o cargo de membro da Junta de Governo Provisório. Já entre 1830 e 1832, ocupou por quatro vezes o governo interino da província, em virtude de ser um dos conselheiros de governo. Portanto, ele acumulou experiência considerável para conhecer

\footnotetext{
${ }^{67}$ ESTADO DO ESPÍRITO SANTO. Assembleia Legislativa (1835-1837). Representação enviada à S. M. O Imperador. 1837.
} 
os rumos da administração provincial, entrando em contato com problemas gerais que afligiam esta pequena porção do Império, como as questões econômicas e de segurança. Nesse sentido, a experiência administrativa foi fundamental para a formação de uma elite política no Espírito Santo, conhecedora das demandas locais, com autoridade para opinar sobre as formas de buscar a satisfação das demandas regionais, que geralmente resultavam em apelos ao Governo Geral, dada a omissão dos Presidentes provinciais, alheios às necessidades locais.

Além do conhecimento das demandas provinciais, a experiência administrativa de grande parte desses deputados deu-lhes condição para promoverem a reorganização administrativa da Província dentro da nova ordem legal estabelecida pelo Ato Adicional. Prova disso são as legislações criadas no período 18351837. Nesse período, a esmagadora maioria das leis versava sobre a reorganização da máquina pública provincial. De trinta leis criadas, 26 se ocupavam de temas administrativos. Alguns exemplos de leis criadas, voltadas para a reorganização administrativa da província são: estabelecimento do número de empregados do governo, normas para impressão de documentos e número de comarcas da província. Já na legislatura seguinte (1838-1839), foram criadas 47 leis ${ }^{68}$. Delas, apenas quinze eram ligadas diretamente à questão de organização administrativa. Portanto, na primeira legislatura houve um esforço bem maior para a organização da estrutura administrativa da Província do Espírito Santo, que contou com a experiência administrativa dos primeiros deputados.

Pode-se encontrar a importância da ocupação de uma carreira política em período anterior à fundação da Assembleia do Espírito Santo por meio da observação de um caso particular. Francisco Pinto Homem de Azevedo, antes de se tornar Deputado Provincial, já havia percorrido uma trajetória política na província do Espírito

\footnotetext{
${ }^{68} \mathrm{~A}$ lista completa dessas leis foi compilada no segundo volume do importantíssimo trabalho de Maria Terezinha Bichara "História do Poder Legislativo do Espírito Santo, 1835-1889".
} 
Santo. Em 1821 foi encontrado como eleitor do representante da Província do Espírito Santo nas Cortes Portuguesas em Lisboa, modo pelo qual teve maior participação na política do Reino Português, que naquele ínterim passava pelos momentos decisivos da definição da situação Portugal - Brasil. Três anos depois, o mesmo cidadão foi encontrado como membro do Conselho Provincial do Espírito Santo, desempenhando a função de administrar essa província junto com outros políticos, passando por um treinamento que lhe possibilitou conhecer mais o Espírito Santo em suas demandas gerais, além de lhe ajudar a compreender o cotidiano dos negócios públicos. Já em 1828, como membro do Conselho de Governo, assumiu interinamente a Presidência da Província do Espírito Santo por causa de uma viagem do Presidente titular, Ignácio Accioli de Vasconcelos. Em 1830, ocupou o cargo de conselheiro do Governo Provincial, função que lhe colocou mais próximo novamente da realidade administrativa. Ainda em 1830, ele assumiu, na condição de Vice-Presidente, a direção da província ${ }^{69}$.

Pode-se apreender dessa trajetória que Francisco Pinto Homem de Azevedo, antes do alvorecer do Império do Brasil, já desempenhava funções de destaque político na ex-Capitania, o que lhe possibilitou conhecer as demandas gerais do Espírito Santo, assim como a estrutura político-administrativa que se formava junto com o Estado brasileiro no início do oitocentos, além do jogo político provincial. Essa experiência foi fundamental para o debate futuro dentro do legislativo do Espírito Santo. Com base nesse histórico pessoal, supõe-se que aqueles ocupantes de cargos políticos institucionais, antes de 1835, tiveram nessas carreiras políticas um dos seus suportes fundamentais para se elevarem a Deputados provinciais e para desenvolverem habilidades para o jogo legislativo constitucional.

Mas não apenas na política institucional os futuros deputados se envolveram. Muitos participaram da política fora dos cargos insti-

${ }^{69}$ DAEMON, Basílio de Carvalho. Província do Espírito Santo. Vitória: 1879. 
tucionais. É o caso de Luiz da Silva Alves de Azambuja Suzano, que teve importante participação nos momentos da Independência. De acordo com relato de $1823^{70}$, solicitou às câmaras da Bahia limítrofes com Espírito Santo “[...] para que subtraíssem ao jugo do infame Madeira, e reconhecessem por soberano a V. M. I. [...]", sendo que, por esses serviços, de acordo com testemunho de Francisco da Silva Alves, recebera o cargo de Secretário da Junta do Governo Provisório, posto que ocupou entre 1821 e 1825.

Outros, porém, estiveram presentes na política provincial em eventos fundamentais, extrapolando seus cargos institucionais. Há o caso já mencionado do trio Luiz da Silva Alves de Azambuja Suzano, José Francisco de Andrade e Almeida Monjardim e Sebastião Vieira Machado, ocupantes da Junta de Governo Provisório, que, com o militar Duarte Carneiro, debelaram a revolta da Julianada, contra a tentativa de unir-se à causa lusitana da vizinha Província da Bahia. Esses quatro indivíduos realizaram no Espírito Santo o papel de representantes do grupo defensor da causa autonomista brasileira. Outros futuros deputados também estiveram envolvidos na causa emancipacionista. Francisco Pinto Homem de Azevedo, por sua vez, foi apresentado como alguém que “[...] sempre mostrou muita adesão à causa do império do Brasil, e da independência, e [da] Augusta Pessoa de Sua Majestade Imperial"11.

Percebe-se, portanto, que o preenchimento do mais alto órgão institucional do Espírito Santo em meados da década de 1830 foi feita por homens que possuíam uma ampla trajetória política, e, por essa razão, estavam preparados para a ocupação desses postos. Não era suficiente o acúmulo de posses materiais para o alcance de popularidade e muito menos de capacitação na arte da política. $\mathrm{Na}$ ordem imperial, de acordo com José Murilo de Carvalho, o grupo

\footnotetext{
${ }^{70}$ BIBLIOTECA NACIONAL. Documento C-0694, 011. nํํ002. 1816-1817. Requerimento encaminhado ao ministério do império solicitando nomeação para secretário do governo da capitania do Espírito Santo.

${ }^{71}$ BIBLIOTECA NACIONAL. Seção de Obras Raras. Documento C-0355, 006. Requerimento encaminhado ao ministério do império solicitando a mercê da Ordem Cristo. 1823-1825.
} 
ocupacional da Economia, formado por proprietários rurais, comerciantes, banqueiros e industriais era o menos preparado politicamente em termos de socialização e treinamento ${ }^{72}$. Portanto, para a ocupação da Assembleia Legislativa do Espírito Santo, em 1835, os deputados da primeira geração provincial tiveram uma preparação especial, envolvendo o acúmulo de teorias específicas, problemáticas, tradições históricas e dados econômicos, como bem defende Pierre Bourdieu ${ }^{73}$, por meio do desenvolvimento de uma carreira político-administrativa que recua no tempo quase três décadas antes da fundação da Assembleia Legislativa do Espírito Santo.

\section{2 - PROFISSÕES DOS DEPUTADOS}

Esses deputados, entretanto, ocuparam outras funções de destaque na sociedade da época, além dos cargos políticos, o que certamente foi fundamental para seus desempenhos no Parlamento. No item anterior, as trajetórias políticas dos deputados foram analisadas enquanto promotoras de uma capacitação política. Por outro lado, para a ocupação de postos de comando institucional não basta apenas a capacitação política técnica, teórica e no domínio das tradições. $O$ ator político deve sua notoriedade específica no campo político à força de mobilização detida. Trata-se de um capital pessoal de notoriedade e popularidade, que geralmente é fruto da transformação de um capital de notoriedade acumulado em outros domínios, particularmente em profissões que permitem um tempo livre e supõem o acúmulo de um capital cultural ${ }^{74}$.

Investigando a carreira desses homens antes de 1835, descobriu-se que três ocupações se destacavam entre eles: a religiosa, a carreira administrativa no Estado e a militar. Alguns desses indi-

\footnotetext{
${ }^{72}$ CARVALHO, José Murilo de. A construção da Ordem: a elite política imperial. Brasília: Editora da Universidade de Brasília, 1981. p. 78.

${ }^{73}$ BOURDIEU, Pierre. 0 Poder Simbólico. Rio de Janeiro: Bertrand Brasil, 2006. p. 169.

${ }^{74}$ BOURDIEU, 2006, p. 190-191.
} 
víduos ocuparam até duas dessas funções. Vale ressaltar que se utilizou, como critério para a categorização desses indivíduos em funções, a proporcionalidade dada pelas fontes na apresentação deles enquanto ocupantes desses cargos. De acordo com as informações encontradas desses personagens, a distribuição fica da seguinte forma:

TABELA 3 - OCUPAÇÕES DOS DEPUTADOS DA PRIMEIRA LEGISLATURA DA ASSEMBLEIA PROVINCIAL DO ESPÍRITO SANTO

\begin{tabular}{|c|c|}
\hline MILITARES & 7 \\
\hline PADRES & 5 \\
\hline FUNCIONÁRIOS PÚBLICOS (FP) & 3 \\
\hline COMERCIANTES & 1 \\
\hline NÃO ENCONTRADOS (NE) & 4 \\
\hline
\end{tabular}

Merece destaque o fato de que, entre os quatro sobre os quais não foram obtidas informações anteriores a 1835, descobriram-se alguns dados correspondentes ao período posterior ao referido ano, mas que não foram computados em virtude de não se ter um indício concreto de que esses "não encontrados" ocupassem essas mesmas funções antes de 1835. É o caso, por exemplo, de João Nepomuceno Gomes Bittencourt, que, no ano de 1860, era rico fazendeiro e comendador. Se os dados da tabela anterior forem colocados na forma de porcentagem, por sua vez, essa distribuição fica, didaticamente, da seguinte forma: 


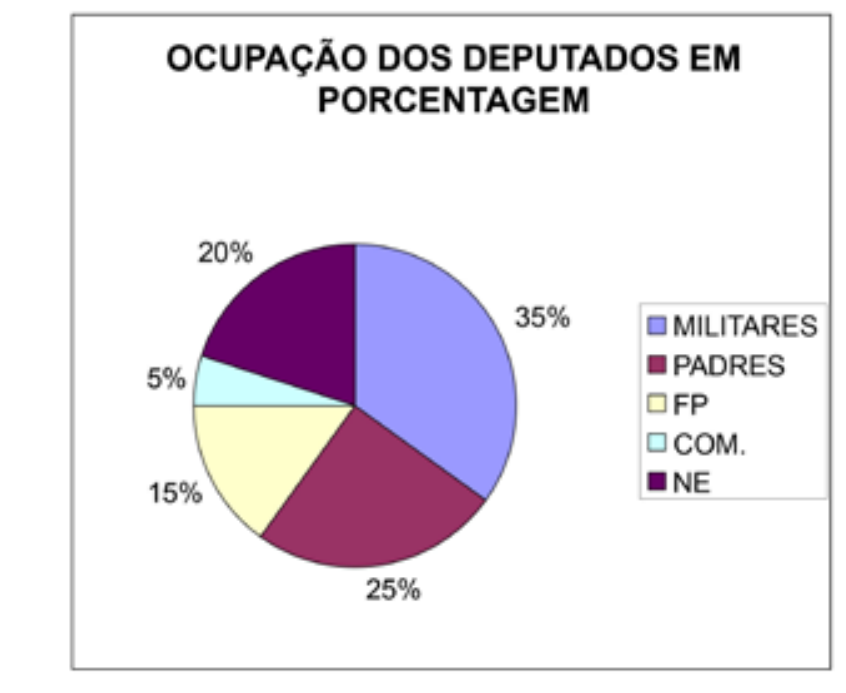

FP = Funcionários Públicos; $\mathrm{COM}=$ Comerciantes; $\mathrm{NE}=\mathrm{Não}$ Encontrados

Num primeiro olhar, já é possível perceber algumas características da primeira legislatura da Assembleia Legislativa do Espírito Santo. Se for cotado o peso numérico de cada grupamento social descoberto, encontra-se um destaque para os militares, seguidos de perto pelos padres e, por fim, pelos funcionários públicos. É importante notar que, dentro desses dados, uma peculiaridade se destaca. É o caso de Francisco Ribeiro Pinto. Esse Deputado foi computado no quadro acima como padre. Esse indivíduo, todavia, desempenhou também o papel de militar. Em 1800, foi encontrado no cargo de capitão, sendo que no dia seis de novembro desse mesmo ano foi um dos que assinaram o importante documento que demarcou os limites entre as capitanias de Minas Gerais e Espírito Santo ${ }^{75}$. Apesar de militar, Ribeiro Pinto não deixou de desempenhar sua função

\footnotetext{
${ }^{75}$ DAEMON, Basílio. História, descoberta e estatística do Espírito Santo. Vitória: Tipografia do Espírito Santo. 1879.
} 
eclesiástica. Em 1812, era capelão da tropa de linha, de maneira que, segundo o clérigo Dom José Caetano da Silva Coutinho, em sua visita ao Espírito Santo, Ribeiro Pinto era Capitão-mor da Vila de Vitória e "o maior figurão da terra", sendo nomeado por D. José presidente das conferências eclesiásticas e examinador sinodal daquele importante eclesiástico. Diante disso, Francisco Ribeiro Pinto era mais um eclesiástico militar do que um militar eclesiástico, ou seja, de acordo com as fontes, as funções eclesiásticas desse personagem destacavam-se das militares, em virtude de que, dentro da corporação militar, ele desempenhava seu ofício religioso ${ }^{76}$.

O gráfico apresenta também a presença de apenas um comerciante, José de Barros Pimentel ${ }^{77}$. É válido relembrar, no entanto, o princípio metodológico para a distribuição dos deputados em ocupações, no caso, o peso que as fontes dão para determinada ocupação de cada um deles. Por outro lado, este trabalho possui a consciência de que esses indivíduos ocuparam mais de um papel social. Diante disso, ressalta-se que as fontes apresentam alguns desses indivíduos, mesmo de maneira pontual, enquanto possuidores de considerável patrimônio material, além de status social advindo de ocupações políticas, profissionais e honoríficas. Daemon, por exemplo, informa que Manoel Pinto Rangel e Silva e Francisco Ribeiro Pinto contribuíram para a manutenção de um hospital de caridade criado em Vitória, em 23 de dezembro de 1817, por decreto de D. João VI ${ }^{78}$. De acordo com Walace Bonicenha, na década de 1810, Francisco Alberto Rubim encaminhou um requerimento de lavradores e comerciantes de Vitória a D. João VI, pedindo que construíssem na vila um hospital para atendimento de enfermos pobres ${ }^{79}$. É provável que Manoel Pinto Rangel e Francisco Ribeiro Pinto estivessem entre os

\footnotetext{
${ }^{76}$ CoUTiNHO, D. José da Silva. Freguesia de Vitória, 1812-1819. Disponível em: <www.estacaocapixaba.com.br>. Acesso em: 14 fev. 2007.

${ }^{77}$ BIBLIOTECA NACIONAL. Documentos Biográficos. Documento C-0837, 008. Requerimento ao ministério do Império. José de Barros Pimentel. 1824-1828.

78 DAEMON, Basílio Carvalho. Província do Espírito Santo. Vitória: 1879. p. 240.

79 BONICENHA, Walace. Devoção e caridade: As irmandades religiosas na cidade de Vitória. Vitória: Editora Multiplicidade. 2004. p. 123.
} 
que pediram a construção dessa obra, pois posteriormente estavam entre os que contribuíram para manter o dito hospital. Vinte anos depois, esses dois personagens tomariam assento na Assembleia Legislativa do Espírito Santo. Certamente, a participação na vida social capixaba por meio dessa contribuição não foi suficiente para inserir esses homens na vida pública. Entretanto, supõe-se que esse evento seja a mostra de que eles eram personagens envolvidos com a importante questão da caridade e que puderam converter seu patrimônio material em prestígio social e político, por meio da contribuição para questões como a caridade.

Outro futuro deputado provincial do Espírito Santo também possuía um rico patrimônio material. Francisco Pinto Homem de Azevedo foi apresentado enquanto o construtor da ponte do rio de Maruípe, obra avaliada em cinco mil cruzados. Dessa quantia, a fazenda provincial gastou apenas entre sete e oito mil réis para a construção. Já Francisco Pinto Homem de Azevedo, para a concretização da ponte, dispôs quatro pedreiros, seis carpinteiros (seus escravos), ferramentas, canoa, madeira grossa tirada das matas de sua propriedade (puxada por seus bois e escravos), além dos recursos líquidos empreendidos nessa empreitada ${ }^{80}$.

É importante destacar isso para esclarecer que este trabalho não tem a pretensão de substituir um determinismo por outro. Ou seja, deixar de dizer que a posse do poderio econômico era o fator predominante para se adentrar à elite política e passar a afirmar que essa elite era composta por aqueles que ascenderam apenas por suas ocupações profissionais, em virtude das teias de relações e bens simbólicos que estas ocupações puderam fornecer.

Ao contrário disso, esta investigação parte do pressuposto de que essas funções institucionais ocupadas (no clero, burocracia e corpo militar) não eram suficientes para que, isoladamente, esses indivíduos fossem projetados aos postos político-institucionais mais

\footnotetext{
${ }^{80}$ BIBLIOTECA NACIONAL. Documento: C-0355, 006. Requerimento encaminhado ao ministério do Império solicitando a mercê da Ordem de Cristo. 1823-1825.
} 
importantes da província. Por outro lado, também não se entende que a riqueza material unicamente seria suficiente para projetá-los na política. Percebe-se, portanto, uma interação entre essas duas dimensões, política e econômica.

Voltando ao caso de Francisco Pinto Homem de Azevedo, esse pressuposto é reafirmado. De acordo com os oficiais da Câmara de Vitória, Francisco Pinto Homem de Azevedo era

[...] um cidadão probo, pacífico, um dos maiores e mais notáveis proprietários, prestável com sua pessoa e bens em qualquer urgência pública, que tem servido os cargos públicos desta câmara e de juiz de órfãos com toda inteireza [...] sempre mostrou muita adesão a causa do império do Brasil, e da independência, e Augusta pessoa de sua Majestade Imperial ${ }^{81}$.

É importante compreender o contexto dessa documentação, que se constitui numa "carta de boas referências", em que Francisco Pinto Homem de Azevedo é apresentado como um "cidadão probo", com o objetivo de ele receber o hábito da Ordem de Cristo pelo Imperador. O interessante nesse testemunho, por outro lado, é que os oficiais da Câmara de Vitória, quando apresentam a importância de Francisco Pinto Homem de Azevedo para o Espírito Santo, não se limitam a destacar a riqueza material desse indivíduo ou o bom uso dela para a Província. Ao contrário, também destacam a importância desse personagem para as instituições políticas locais. Sendo assim, Francisco Pinto Homem de Azevedo é descrito como um bom servidor da Câmara e, dentro da burocracia, como Juiz dos Órfãos, além de sempre mostrar "[...] muita adesão a causa do Império do Brasil, e da independência, e Augusta Pessoa de Sua Majestade Imperial [...]". Entende-se, a partir desse testemunho, que, para Francisco Pinto Homem de Azevedo projetar-se politicamente, ele teve como suporte não apenas sua vasta riqueza material (utilizada em muitos

\footnotetext{
${ }^{81}$ BIBLIOTECA NACIONAL. Documento: C-0355, 006. Requerimento encaminhado ao ministério do Império solicitando a mercê da Ordem de Cristo. 1823-1825.
} 
momentos para a prosperidade do Espírito Santo, o que certamente lhe proporcionou uma considerável projeção local), mas também sua carreira enquanto burocrata, vereador, membro do Conselho Provincial do Espírito Santo e participante de momentos cruciais da política local e nacional o fixaram enquanto um destacável homem público local. Tanto que a reivindicação do hábito da Ordem de Cristo foi atendida por D. Pedro I ainda em 1825. Não se deve esquecer também que Francisco Pinto Homem de Azevedo foi destacado militar, sendo encontrado como Coronel do Estado Maior em 1814 e Capitão-Mor da Província em 1829. Temos, então, diferentes papéis desempenhados por um mesmo indivíduo: burocrata, grande homem de negócios, militar e atuante nos momentos cruciais da política provincial e nacional. Esses diferentes papéis permitiram a construção de um importante círculo de relações à sua volta, envolvendo laços políticos e pessoais.

Pode-se afirmar que, se a categorização desses indivíduos nessas funções, como mostrado no gráfico anterior, é uma opção metodológica para se analisar a carreira dos deputados da primeira legislatura da Assembleia Legislativa do Espírito Santo, ela é também uma opção consciente da complexidade que envolvia a vida social desses indivíduos.

Outro indivíduo de posses era o militar Manoel da Siqueira e Sá Júnior. Mostra disso é que, em 1819, ele foi encontrado queixando-se à Majestade Imperial contra uma taxação que considerava abusiva: ele era dono da sumaca ${ }^{82}$ Nossa Senhora da Guia, que estava carregada de mantimentos e madeiras na Aldeia Velha dos Reis, seguindo viagem para a Vila de Vitória, onde se conservou carregada em todo mês de maio para sair para a Bahia. Sá Júnior despachou sua embarcação para esse destino, mas ela não pôde sair no dia marcado por causa de um inconveniente. Logo depois foi baixado um edital para se pagarem emolumentos impostos aos gêneros de exportação com a finalidade de se fundar um novo hospital em Vitória. Por causa

${ }^{82}$ Barco à vela. 
desse edital, Manoel da Siqueira e Sá Júnior teve que pagar emolumentos dos gêneros embarcados ${ }^{83}$, motivo de sua queixa. Portanto, Manoel da Siqueira e Sá Júnior, além de militar, também era um importante comerciante provincial, comercializando suas mercadorias para fora da província.

\subsection{1 - Trajetórias no Império e no Espírito Santo}

Comparando as porcentagens de ocupação da primeira legislatura da Assembleia Legislativa do Espírito Santo com informações nacionais em período aproximado, surgem alguns resultados interessantes. A Câmara dos Deputados, na legislatura de 1834 a 1838, em relação às mesmas ocupações encontradas no Espírito Santo, tinha entre seus componentes um percentual de $11 \%$ de militares, $23,08 \%$ de padres e $24,04 \%$ de magistrados (funcionalismo público) ${ }^{84}$. A diferença maior na comparação desses dados locais e gerais está no caso dos militares. Enquanto na corte um pouco mais de um décimo dos deputados era da tradição de armas, no Espírito Santo esse número sobe para mais de um terço. Em relação aos padres, a diferença entre Espírito Santo e Governo Geral é menor, abaixo de dois pontos percentuais. No caso dos funcionários públicos, a diferença é considerável, de cinco pontos percentuais. Esses números ficam mais claros de acordo com o gráfico a seguir (FIGURA 2):

\footnotetext{
83 BIBLIOTECA NACIONAL. Documentos Biográficos. Documento C-0114, 040. Documentos referentes a Manoel da Siqueira e Sá 1830-1855.

${ }^{84}$ CARVALHO, José Murilo de. A construção da ordem: a elite política imperial. Rio de Janeiro: Campus, 1980. p. 83.
} 
FIGURA 2

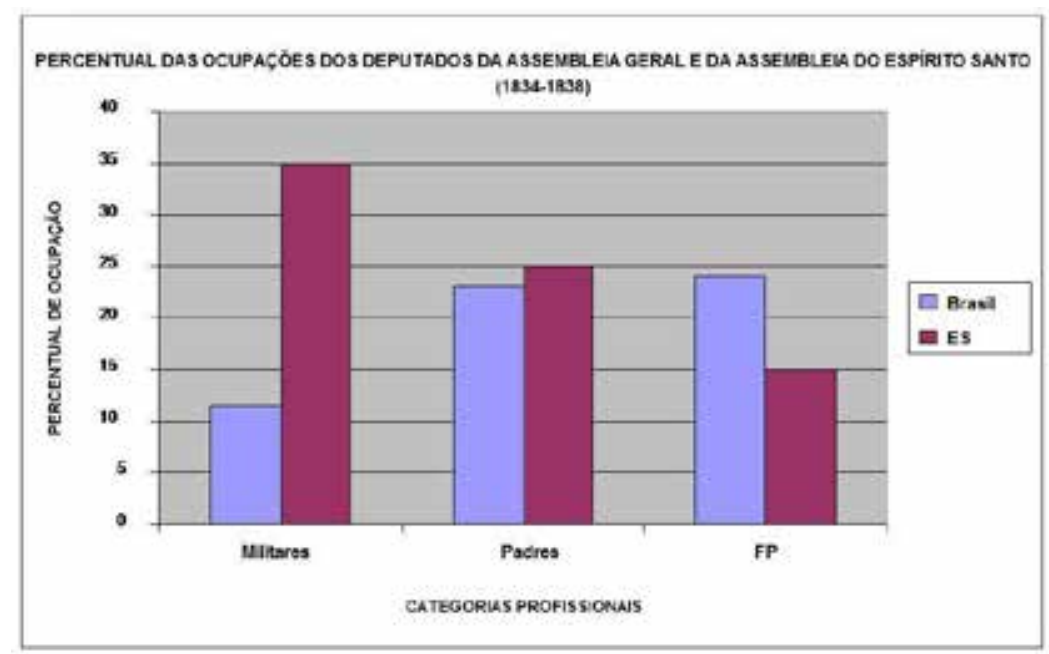

A partir do gráfico, dimensiona-se a grande diferença entre o peso dos militares no âmbito nacional e no Espírito Santo, com uma maior presença dessa categoria na Província, pelo menos no período em questão. No caso dos padres, nota-se uma semelhança quanto à presença destes nas assembleias. Em relação aos funcionários públicos, por sua vez, percebe-se um peso maior dessa categoria em âmbito nacional em relação ao Espírito Santo.

Essa comparação é necessária em virtude de mostrar como o Espírito Santo, nesse caso, possuía um matiz diferente dentro da realidade nacional. Enquanto em âmbito nacional, de acordo com José Murilo de Carvalho ${ }^{85}$, a construção do Estado na primeira metade do século dezenove teve como protagonista uma elite política caracterizada pela baixa presença de militares, uma elite civil, o Espírito Santo teve como realidade uma elite política com a presença marcante de militares. Um grupo militar que teve contato

${ }^{85}$ CARVALHO, 1980, p. 83. 
com diversas crises de segurança provincial anteriormente a 1835, e que, uma vez no parlamento, tentou levar uma política pacificadora da localidade.

Como a Assembleia Legislativa Provincial foi criada num momento altamente conturbado por revoltas provinciais (o período das regências), é notável que, em uma Assembleia com mais de um terço de seus componentes sendo militares, estes não tentassem satisfazer as demandas locais pela via armada contra o governo central. Supõe-se que isso não ocorreu no Espírito Santo em virtude de o resto dos componentes da Assembleia Legislativa ser formado, em sua esmagadora maioria, por padres e funcionários públicos. Por essa formação, a Assembleia Legislativa, em sua primeira legislatura, preocupou-se mais, no momento de legislar, com a estruturação da ordem administrativa da província, como exposto anteriormente. Além disso, percebe-se que o grupo militar aqui estabelecido possuía, desde momentos anteriores, um compromisso com a manutenção da ordem. O exemplo clássico da Julianada demonstra isso. O militar Duarte Carneiro, como visto, se aliou aos líderes civis da Junta de Governo Provisório contra a iniciativa de Julião Leão em apoiar a causa portuguesa do Brigadeiro Madeira, da Bahia. Nesse sentido, os militares, desde o início do XIX, desenvolviam um projeto político que concebia a existência do Espírito Santo enquanto uma das unidades políticas de um Brasil independente.

\subsection{2 - Carreiras}

O grupo que ocupou a primeira legislatura da Assembleia Legislativa Provincial do Espírito Santo forjou-se desde o início do oitocentos e teve sua consolidação no momento de fundação da Assembleia Legislativa. Notou-se como peculiaridade desse grupo social que, entre seus componentes, havia três ocupações predominantes: os militares, os padres e os funcionários públicos. A seguir, esses grupos serão analisados de maneira mais minuciosa. 


\subsubsection{1 - Deputados da Espada}

Encontraram-se sete militares entre os eleitos para a Assembleia Legislativa instalada em 1835 no Espírito Santo. Esses militares ocuparam seus postos em organizações provinciais desde o início do oitocentos, confundindo-se com a história militar da província. Como visto no capítulo primeiro, o Espírito Santo não era uma província marcada sempre pela calmaria mas, ao contrário, vez por outra era atravessada por distúrbios, conflitos, revoltas e insurreições que demandavam a atuação das forças militares.

$\mathrm{Na}$ virada do século XVIII para o XIX, a província do Espírito Santo era guardada por ordenanças e corpos milicianos estabelecidos pela metrópole portuguesa. Alguns dos que ocuparam a primeira legislatura da Assembleia Legislativa do Espírito Santo circularam por essas instituições militares antes de 1835. Na tabela abaixo, são apresentados esses homens das armas e as patentes por eles ocupados nos corpos militares:

TABELA 4 - MILITARES DA PRIMEIRA LEGISLATURA DA

ASSEMBLEIA DO ESPÍRITO SANTO

\begin{tabular}{l|l}
\multicolumn{1}{c|}{ NOMES } & \multicolumn{1}{c}{ PATENTES } \\
\hline Manoel da Silva Maia & TENENTE \\
José Francisco de A. A. Monjardim & CAPITÃO \\
Sebastião Vieira Machado & CAPITÃO \\
Dionízio Álvaro Rezendo & OFICIAL MAIOR \\
Inácio Pereira Duarte Carneiro & COMANDANTE DE ARMAS \\
Francisco Pinto Homem de Azevedo & CORONEL \\
Manoel da Siqueira e Sá & CAPITÃO \\
\hline
\end{tabular}

No caso dos militares, essa formação propiciou uma capacitação específica para o exercício da carreira política numa instituição dentro dos quadros constitucionais e parlamentares. Apesar de a carreira desses militares ser marcada por embates contra os 
movimentos que, por alguns momentos, trouxeram instabilidade para o Espírito Santo, pressupõe-se que essa experiência trouxe a esses homens um conhecimento maior da capitania, tanto a nível social quanto político. No âmbito social, esses militares conheceram, por meio do enfrentamento das revoltas e circulação dentro da província e da mudança de cargos, diversas demandas presentes no Espírito Santo, demandas essas que no futuro seriam processadas dentro do jogo democrático da Assembleia Legislativa. Outra capacitação trazida pela carreira militar foi o vislumbre do contexto político que se forjava na província. No enfrentamento das revoltas, esse grupo contribuiu para a formação de uma elite política com tradição emancipacionista em relação a Portugal. Além disso, nessas revoltas, essa elite em formação pôde entrar em contato com o clima político do Espírito Santo e com o que poderia trazer uma perturbação desse contexto. Nesse sentido, a carreira militar na província do Espírito Santo permitiu a esses homens a absorção de conhecimentos, informações e capacitações fundamentais para a específica competência da política ${ }^{86}$. Essas capacitações seriam essenciais para a condução do processo legislativo a partir de 1835 . Isso porque a elite política do Espírito Santo, nesse momento instalada no parlamento, teve a função de receber as demandas sociopolíticas da província e processá-las institucionalmente, ou seja, transformá-las em instrumentos de força legal, ou enviá-las ao governo central na forma de representações, pedindo para que o polo de poder nacional resolvesse essas questões.

Outra mostra da importância dessa carreira militar está no acontecimento da Julianada, no limiar da independência, descrita no capítulo primeiro. Nesse caso, o militar Ignácio Pereira Duarte Carneiro se predispôs a apoiar a Junta de Governo contra Julião Leão, opositor à emancipação do Brasil em relação a Portugal. Como visto, o militar se armou e defendeu belicamente a Junta contra as investidas de Julião Leão. Num primeiro momento, Ignácio

${ }^{86}$ BOURDIEU, 2006, p. 169. 
Pereira Duarte Carneiro em pessoa participou do desvio da escuna Leopard que levava o Capitão Luís Bartolomeu da Silva e Oliveira, que fora desprestigiado por Julião Leão. Nesse caso, de arma em punho, se opôs à soldadesca que guardava o Capitão Luís Bartolomeu $^{87}$. Na batalha final da Julianada, Duarte Carneiro em pessoa também comandou as tropas que defenderam o Palácio do Governo contra as forças de Julião Leão. Nesse episódio, Ignácio Pereira Duarte Carneiro, como militar, apresentou-se claramente como um defensor da causa emancipacionista no Espírito Santo. Assim, nessa situação de crise, por meio de sua atuação individual, Duarte Carneiro reuniu aquilo que Pierre Bourdieu ${ }^{88}$ denomina de capital pessoal heroico ou profético, também chamado de carisma por Max Weber. O capital pessoal heroico ou profético [...] "é produto de uma ação inaugural, realizada em situação de crise, no vazio e no silêncio deixados pelas instituições e os aparelhos". Esse capital, também um tipo de capital político, foi importantíssimo para a projeção de Ignácio Pereira Duarte Carneiro dentro do Espírito Santo. Numa conjuntura em que as instituições nacionais e provinciais ainda não estavam plenamente estabilizadas, ele fez de sua atitude em defesa da ordem que se construía um suporte para principiar seu carisma diante dos provinciais.

Nesse processo, se pôs ao lado de um grupo que se formava com uma tendência política favorável a um projeto específico: elevar o Espírito Santo à categoria de província vinculada a uma corporação política independente da metrópole. Nesse momento ocupavam a Junta de Governo Provisório José Nunes da Silva Pires (Presidente); Luiz da Silva Alves de Azambuja Suzano (Secretário); José Francisco de Andrade e Almeida Monjardim; José Ribeiro Pinto e Sebastião Vieira Machado. Desses, três tornar-se-iam componentes da primeira legislatura da Assembleia Legislativa Provincial. Percebe-se, portanto, que esse evento militar, mas de caráter

\footnotetext{
${ }^{87}$ NOVAES, Maria Stella de. História do Espírito Santo. Vitória: FEES, [19-]. p. 136.

${ }^{88}$ BOURDIEU, Pierre. O Poder Simbólico. Rio de Janeiro: Bertrand Brasil, 2006. p. 191.
} 
também político, serviu para o encontro entre autoridades que se aproximavam e consolidavam um projeto de poder para o Espírito Santo, que seria levado para as vias institucionais na fundação da Assembleia Legislativa. O desenvolvimento desses laços políticos seria fundamental para uma convivência dentro do jogo político institucional e parlamentar a partir de 1835.

\subsubsection{2 - Deputados do Altar}

Os clérigos compunham o segundo maior grupo de componentes da primeira legislatura da Assembleia Provincial do Espírito Santo. A história religiosa do Espírito Santo, dentro do processo de colonização portuguesa, tem como ponto fundamental o ano de 1535, quando foi criado o primeiro templo cristão do Espírito Santo, a Igreja de Nossa Senhora do Rosário, na Vila do Espírito Santo, que abrigou a sede primitiva da Irmandade da Misericórdia. No mesmo local, no ano de 1545, procedeu-se a fundação da Santa Casa de Misericórdia, para realização de trabalhos assistenciais. Em 1554, tem-se a criação da Confraria da Caridade, pelo Padre Brás Lourenço, para combater as "injurias e maledicências". Os membros dessa confraria eram obrigados a comungar nas primeiras festas do ano e "conter a língua" em relação ao próximo. Infratores desses preceitos pagavam multa, sendo o valor recebido revertido em benefício do casamento de órfãs. Já no ano de 1632, tem-se a criação da Prelazia (jurisdição territorial, sem grandes recursos, subordinada ao Bispado) de Vitória, com clero subordinado ao Bispado do Rio de Janeiro até $1892^{89}$.

Em meados do XVIII, a vida religiosa católica do Espírito Santo sofreu duro golpe. Em 1759, os jesuítas foram expulsos da colônia. Como consequência, os indígenas voltaram à vida fora dos moldes colonizadores, prejudicando a agricultura antes por eles praticada.

${ }^{89}$ BONICENHA, 2004, p. 32-63. 
O ensino também desapareceu e as três fazendas jesuíticas (Muribeca, Araçatiba, Itapoca), que eram as mais produtivas da capitania, caíram em total decadência ${ }^{90}$. No início do século XIX, entretanto, a religiosidade cristã do Espírito Santo teve um refrigério, pelo menos institucional: em 1819, por provisão régia, foi criada a jurisdição de arcebispado no Espírito Santo ${ }^{91}$, dando maior independência para o clero capixaba.

Os padres que assumiram a deputação na primeira legislatura da Assembleia Provincial do Espírito Santo tinham como grande particularidade a destacada formação e interessante produção intelectual, principalmente no âmbito da literatura. Como visto no capítulo anterior, cinco padres galgaram o posto de deputados provinciais em 1835: João Clímaco de Alvarenga Rangel, João Luiz da Fraga Loureiro, Manoel da Assunção Pereira, Ignácio Félis de Alvarenga Sales e Francisco Ribeiro Pinto.

Esses clérigos já se faziam presentes na vida pública do Espírito Santo antes de 1835. Manoel da Assunção Pereira, por exemplo, em 1817 foi apresentado ao Bispo pelo próprio Rei D. João VI, na Paróquia de Nossa Senhora da Conceição da Serra do Espírito Santo deste Bispado, para que recebesse a pensão anual de 10.000 réis com a finalidade da construção da real capela ${ }^{92}$. Percebe-se a projeção desse clérigo na medida em que recebeu a incumbência da construção da capela real. Outro caso notável é o do padre Francisco Ribeiro Pinto. No ano de 1825 esse então futuro deputado teve uma atitude de importante caráter simbólico, doando sua côngrua em benefício das despesas do Estado, o que foi imitado por muitas outras pessoas. Não se pode perceber a real intenção de Francisco Ribeiro Pinto nesse ato, mas o interessante é que ele possuiu intensa repercussão local, tanto que foi imitado por outros. Nesse sentido, Francisco Ribeiro Pinto convertia seu capital material em capital simbólico, o que

\footnotetext{
${ }^{90}$ LEAL, J. E. Franklin. Economia Colonial Capixaba. Cuca: Cultura Capixaba. Vitória, n. 0, fev. 1977.

${ }^{91}$ BONICENHA, 2004, p. 55.

${ }^{92}$ BIBLIOTECA NACIONAL. C 162, 15. Documentos referentes a Manuel da Assunção Pereira.
} 
certamente foi fundamental para se apresentar enquanto homem digno de receber a posição de deputado. Francisco Ribeiro Pinto possuía papéis de suma relevância no Espírito Santo antes da década de 1830. De 1812 a 1825, verificou-se que esse clérigo ocupou o cargo de capelão da capela dos jesuítas ${ }^{93}$. Além disso, em 1812 era Capelão da Tropa de Linha e, segundo D. José Caetano da Silva Coutinho, Bispo do Rio de Janeiro, Francisco Pinto era capitão-mor da Vila de Vitória, em 1819, e "o maior figurão da terra". A seguir, foi nomeado presidente das conferências eclesiásticas e examinador sinodal do Bispo Coutinho ${ }^{4}$. D. Coutinho, que fora celebrante da missa pontifical que sagrara e ungira D. Pedro I Imperador ${ }^{95}$, nomeou Francisco Ribeiro Pinto capelão da Igreja do Colégio de Santiago.

As carreiras clericais foram fundamentais para a projeção política desses deputados. Concederam a esses homens aquilo que Pierre Bourdieu ${ }^{96}$ chama de capital delegado da autoridade política. Esse capital político específico é controlado por uma instituição que, por sua vez, o doa a seus membros. A instituição investe o membro desse capital político, numa recompensa ao tempo, trabalho e devoção a ela dedicados. A instituição é a concedente de notoriedade àqueles investidos de poder. Isso se coaduna à condição dos padres. A Igreja lhes concede o poder de atuarem dentro dessa instituição e gozarem dos benefícios do seu pertencimento. Aqueles que mais se destacam ganham notoriedade e galgam cargos mais altos. No Espírito Santo, isso foi fundamental para que homens (por meio da igreja) recebessem uma notoriedade na comunidade, garantindo-lhes projeção política.

\footnotetext{
${ }^{93}$ DAEMON, Basílio Carvalho. Espírito Santo: sua descoberta, História cronológica, sinopse e estatística. Vitória: Tipografia do Espírito Santo. 1879.

${ }^{94}$ SILVA, José Caetano. Freguesia de Vitória, 1812-1819. Disponível em: <estacaocapixaba. com.br>. Acesso em: 14 fev. 2007.

${ }^{95}$ SCHWACZ, Lilia Moritz. As barbas do Imperador: D. Pedro II, um imperador nos trópicos. São Paulo: Companhia das Letras, 2006. p. 39.

${ }^{96}$ BOURDIEU, 2006. p. 191-193.
} 


\subsubsection{3 - Deputados da Burocracia}

Entre os ocupantes da primeira legislatura da Assembleia do Espírito Santo, alguns atuaram em destaque no âmbito administrativo, como informa a tabela abaixo:

TABELA 5 - FUNCIONÁRIOS PÚBLICOS DA PRIMEIRA LEGISLATURA DA ASSEMBLEIA LEGISLATIVA DO ESPIRITO SANTO

\begin{tabular}{l|l}
\multicolumn{1}{c|}{ NOMES } & \multicolumn{1}{c}{ CARGO } \\
\hline Luiz da Silva A de Azambuja Suzano & ESCRITURÁRIO, JUIZ \\
Manoel de Morais Coutinho & JUIZ, PROMOTOR \\
Manoel Pinto Rangel e Silva & JUIZ \\
\hline
\end{tabular}

Figura que se destacou por essa tradição na burocracia foi o Deputado Luiz da Silva Alves de Azambuja Suzano. Esse personagem foi encontrado em 1821 como escriturário ${ }^{97}$ da Junta de Fazenda2 ${ }^{98}$ permanecendo no cargo ainda no ano seguinte. Em 1822 ainda era Juiz de Paz e Juiz de Órfãos, mas entre a Independência e a Constituição de 1824, Azambuja Suzano já assumia o posto político de membro da Junta Provisória, criada no início de março de 1822, atuando como secretário ${ }^{99}$.

Percebe-se que Azambuja Suzano serviu à administração pública tanto na área burocrática estrita quanto no setor de justiça. Como escriturário da Junta da Fazenda, acessou as questões financeiras do Espírito Santo. No âmbito jurídico, teve contato com demandas locais. Como Juiz de Órfãos, solucionava questões de herança, com atenção aos herdeiros. Como Juiz de Paz, tinha que resolver

\footnotetext{
${ }^{97}$ PENA, Misael Ferreira. História da Província do Espírito Santo. Rio de Janeiro: Tipografia de Moreira, 1878. p. 108.

${ }^{98}$ A junta de Fazenda foi criada pelo governo Português em 29/05/1809 com as atribuições de conhecimento e inspeção de todos os objetos da arrecadação e administração do patrimônio régio na capitania.

${ }^{99}$ CLAÚDIO, Afonso. História da Literatura Espírito Santense. Rio de Janeiro: Biblioteca reprográfica xerox, 1981. p. 108-139.
} 
pequenas questões locais e policiais. Percebe-se o envolvimento do ocupante dessas funções jurídicas em situações cotidianas e até de foro íntimo. Supõe-se que esse envolvimento poderia resultar ao ocupante desses cargos o conhecimento por parte da população e o reconhecimento como alguém de confiança. A partir dessa autoridade jurídica, o ocupante do cargo judiciário poderia desenvolver laços de sociabilidade fundamentais para uma carreira política.

A passagem de Azambuja Suzano pelos quadros administrativos estatais permitiu, possivelmente, sua configuração como ator político coletivo com maior poder de barganha ${ }^{100}$.

A função burocrática alçou-o a uma posição de destaque social em meio da conjuntura político-social do Espírito Santo do início do oitocentos, além das funções administrativas darem-lhe conhecimento das necessidades provinciais, fatores que certamente pesaram no momento de sua escolha para deputado da Assembleia Legislativa Provincial do Espírito Santo.

Pierre Bourdieu ${ }^{101}$ também considera o funcionário enquanto um receptor do capital delegado da autoridade política. No caso em tela, alguns dos ocupantes da Assembleia Legislativa do Espírito Santo em 1835 haviam passado pela experiência da burocracia civil. Portanto, foram políticos que tiveram uma ocupação na instituição do Estado, sendo nele investidos de autoridade e através dele podendo acumular experiência administrativa, sendo conhecidos na província. José Murilo de Carvalho ${ }^{102}$ também supõe que o emprego público seria a ocupação que mais favorecia uma orientação estadista, treinando os ocupantes da burocracia para as tarefas de construção do Estado na fase inicial desse processo, e no caso em tela, da organização política do Espírito Santo com uma maior autonomia.

Praticamente todos os indivíduos sobre os quais se encontrou informação tinham suas carreiras ligadas ao Estado. Militares e Burocracia Civil constituíam, e constituem, ocupações posicionadas

\footnotetext{
${ }^{100}$ CARVALHO, 1981. p. 115.

${ }^{101}$ BOURDIEU, 2006. p. 191-192.

${ }^{102}$ CARVALHO, 1981. p. 76.
} 
dentro da máquina do Estado Moderno. O terceiro grupo encontrado, os Padres, no contexto Imperial brasileiro também compunha o funcionalismo do Estado. Apesar de fazer parte da hierarquia da igreja, o padre do período imperial também era um funcionário público. O Estado Brasileiro desse período persistiu em não abrir mão da união com a Igreja Católica, pois esta era um recurso administrativo barato e possuía grande poder sobre a população. Os párocos eram os únicos agentes do governo central em nível local, realizando a tarefa administrativa do registro estatístico, tendo também uma importância político-eleitoral ${ }^{103}$.

Nesses termos, pode-se concluir que dos vinte membros da primeira legislatura da Assembleia Legislativa do Espírito Santo quinze tinham como ocupação o funcionalismo público, sendo que internamente a esse quantitativo os militares predominavam. Essa característica refletia, dentro das modulações locais, a conjuntura vivida pelo Brasil daqueles tempos, visto que uma das principais características da elite política imperial era o seu estreito relacionamento com a burocracia do Estado ${ }^{104}$.

Como característica local, estava o grande quantitativo de deputados que fizeram sua carreira profissional em ocupações militares, diferentemente do cenário nacional, no qual predominava a burocracia civil dentro da elite política. As experiências trazidas pelas carreiras dentro do Estado permitiram no Espírito Santo a formação de uma elite provincial conhecedora dos problemas sociais e econômicos locais. Essa elite era capacitada para a condução de demandas socioeconômicas, dentro de um quadro institucional que primava por uma estabilidade política nos moldes do Estado que se forjava no Brasil da primeira metade do século XIX.

${ }^{103}$ CARVALHO, 1981. p. 120-147.

${ }^{104}$ CARVALHO, 1981. p. 111. 


\section{3 - TRAJETÓRIAS CRUZADAS}

\section{1 - ENCONTROS ANTES DE 1835}

Como já foi dito, a proposta em tela é mostrar como os membros da elite política que se instalou na Assembleia Legislativa do Espírito Santo tiveram uma socialização no decorrer de suas ocupações profissionais e políticas antes de 1835; é evidenciar como obtiveram certo grau de coesão para que, no momento em que se encontraram na fundação da Assembleia Legislativa Provincial, tenham podido conduzir um projeto político específico para a Província do Espírito Santo.

Essa socialização, por sua vez, deu-se dentro do Estado, na ocupação de três funções específicas: área militar, clero e burocracia civil. Essas carreiras dentro do Estado promoveram a transmissão de valores e o treinamento ${ }^{105}$. Apreende-se que, na primeira metade do século dezenove, a elite política do Espírito Santo possuía uma tendência estadista, em virtude de sua formação prática dentro da administração pública. Além disso, grande parte desses funcionários também ocupou cargos políticos antes de 1835 na estrutura provin-

${ }^{105}$ CARVALHO, José Murilo de. A construção da ordem: a elite política imperial. Rio de Janeiro: Campus, 1980. p. 73. 
cial, encontrando-se entre si nessas funções institucionais. Com os dados levantados, montou-se o seguinte gráfico, para mostrar esses encontros antes da formação da Assembleia Provincial:

FIGURA 3 - LAÇOS SOCIOPOLÍTICOS DOS DEPUTADOS DA PRIMEIRA LEGISLATURA

DA ASSEMBLEIA DO ESPÍRITO SANTO

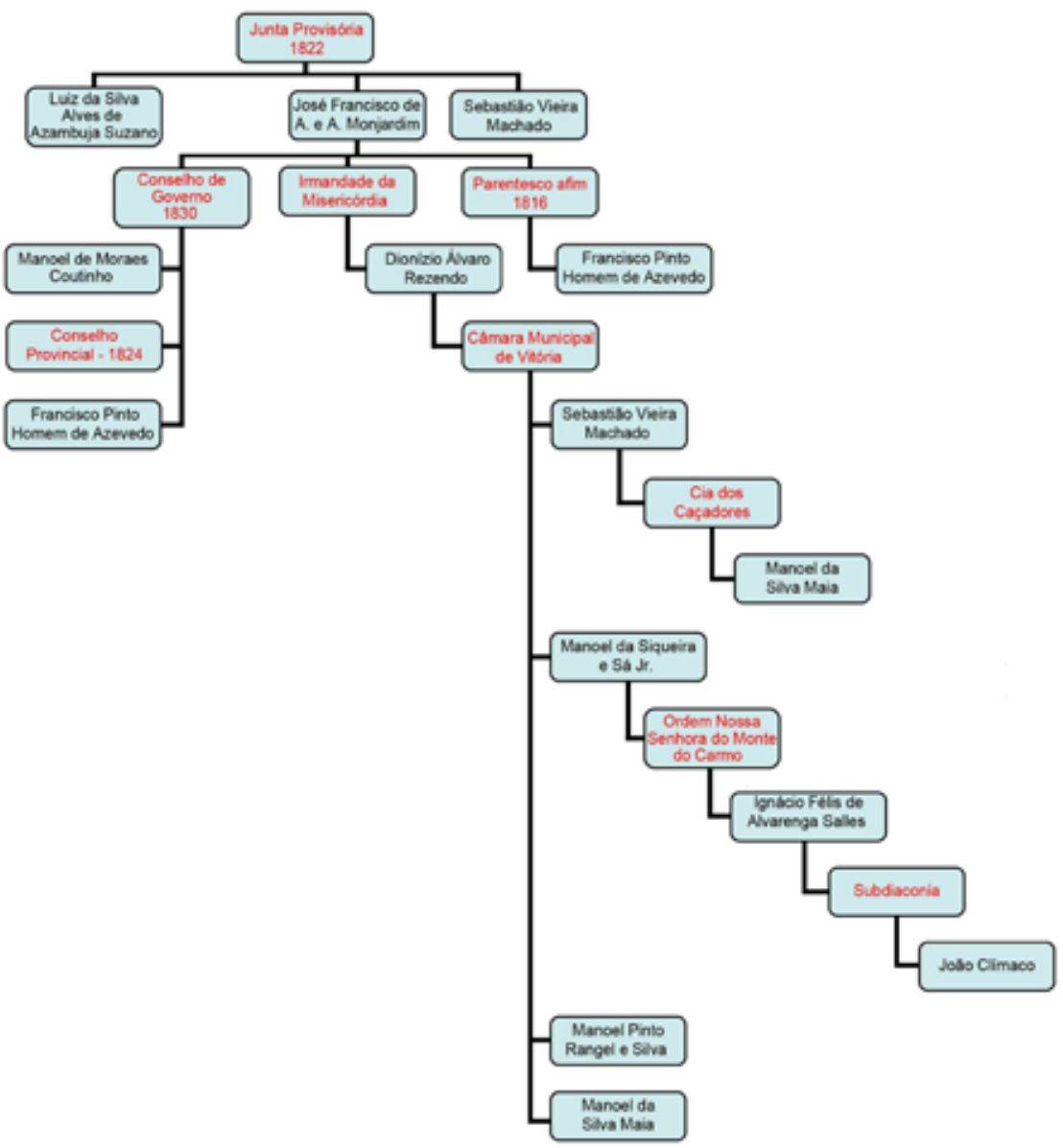


Pelo organograma, é possível identificar vários pontos em que os futuros deputados se encontraram e puderam socializar. Como dito anteriormente, os militares, os padres e os burocratas civis se destacaram na formação da primeira legislatura da Assembleia Legislativa do Espírito Santo. Ou seja, essa elite era formada basicamente por indivíduos de carreiras profissionais feitas dentro da administração do Estado. A ocupação serve como um importante fator de unificação da elite, pois por meio dela podem-se transmitir valores, treinamento e uma base de interesses materiais ${ }^{106}$. Além disso, viu-se que alguns deputados ocuparam cargos em instituições políticas anteriormente a 1835 , encontrando-se em algumas delas. Portanto, laços político-institucionais, familiares, militares e de ocupação aproximaram alguns desses homens, derivando em uma maior unidade no futuro. O organograma, por sua vez, apresenta alguns desses pontos de encontro.

Em 1822, houve o encontro dos futuros deputados Luiz da Silva Alves de Azambuja Suzano, José Francisco de Andrade e Almeida Monjardim e Sebastião Vieira Machado em um órgão eminentemente político-administrativo, a Junta de Governo Provisório. Esses personagens, junto de outros, compartilharam a experiência de momentos fulcrais da política provincial. Um desses momentos, narrado anteriormente, foi o movimento da Julianada, que se opunha no Espírito Santo à emancipação do Brasil. Nesse evento, a Junta teve que se organizar e buscar uma coerência interna para desarticular o movimento golpista de Julião Leão. Além disso, os membros da Junta, como exposto anteriormente, contaram com o determinante ato de solidariedade política de Inácio Pereira Duarte Carneiro, fundamental para uma aproximação de interesses que futuramente seriam primordiais para a coerência interna do parlamento. Nesse sentido, a oposição a um inimigo comum, que ameaçava a emancipação, promoveu uma singular experiência de contato

\footnotetext{
${ }^{106}$ CARVALHO, José Murilo de. A construção da Ordem: a elite política imperial. Brasília: Ed. da Universidade de Brasília, 1981. p. 73.
} 
político entre os quatro personagens políticos acima mencionados.

Em 1824, por sua vez, dois outros futuros deputados provinciais se encontrariam em um órgão de intenso cunho político. Nesse ano, Francisco Pinto Homem de Azevedo e Manuel Morais Coutinho foram eleitos membros do Conselho Provincial ${ }^{107}$. Como apresentado, os Conselhos Provinciais não possuíam autonomia para criar leis, podendo apenas criar projetos que seriam encaminhados para a Assembleia Nacional, onde seriam aprovados ou não. Apesar dessa limitação, tais conselhos convertiam-se em espaços onde a discussão política institucional poderia ser desenvolvida, em virtude de, nessas instituições, ser necessário o debate para a criação dos projetos a serem enviados ao parlamento nacional. Esses conselhos, portanto, se constituíram em locais onde se tornou possível o treinamento para uma futura vida legislativa, dando aos seus participantes experiência política institucional, fundamental para sua atuação dentro das futuras assembleias provinciais. Desse modo, esses dois deputados compartilharam de uma vivência legislativa antes de 1835. o caso de Francisco Pinto Homem de Azevedo é mais emblemático, pois sua atuação política nesse conselho somou-se à sua vasta experiência administrativa, como foi apresentado anteriormente.

Cinco anos antes do início de funcionamento da Assembleia Legislativa Provincial do Espírito Santo, Manoel de Morais Coutinho e Francisco Pinto Homem de Azevedo mais uma vez se encontraram em cenário político específico, dessa vez o Conselho de Governo. Esse conselho substituiu a Junta Provisória a partir de 1823 com a função de administrar a província, sendo liderado pelo Presidente da Província, substituído, no caso de ausência, por um vice, que, por sua vez, também pertencia ao mesmo conselho.

No ano de 1830, Manoel de Moraes Coutinho, José Francisco de Andrade e Almeida Monjardim e Francisco Pinto Homem de Azevedo participavam do Conselho de Governo do Espírito Santo. Essa expe-

\footnotetext{
${ }^{107}$ OLIVEIRA, José Teixeira de. História do Estado do Espírito Santo. Rio de Janeiro: Oficinas do Serviço Gráfico do IBGE, 1975. p. 284.
} 
riência certamente permitiu a esses políticos uma maior aproximação, em virtude de terem que chegar a um consenso mínimo para auxiliar o Presidente na administração local. Além disso, essa experiência também consolidou uma perspectiva mais administrativa e institucional da política, o que seria fundamental para que esses políticos conduzissem a articulação das demandas socioeconômicas em demandas institucionais a serem encaminhadas ao Governo Geral.

Como visto antes, laços não políticos também contribuíram para a aproximação desses personagens. A Irmandade da Misericórdia, por exemplo, foi um dos grupos de socialização de alguns desses indivíduos. As irmandades e as confrarias constituíam-se em associações de leigos com objetivos religiosos e assistenciais. As irmandades surgiram, no medievo, como grupos organizados por certas categorias profissionais para mútua ajuda entre seus componentes e facilitação da profissão, paralelamente ao surgimento de novas tendências de pensamento religioso, como as ordens mendicantes. Maurice Agulhon ${ }^{108}$ distinguiu duas categorias principais de irmandades, as do tipo confraria-associação e as da categoria confraria-instituição. As irmandades do segundo grupo, além de congregarem seus membros com finalidades religiosas e de ajuda mútua entre os associados, também se dedicavam ao serviço àqueles que estavam fora do rol de membros da associação. Um exemplo das irmandades do tipo confraria-instituição são aquelas que administram hospitais, como a Irmandade da Misericórdia. As Misericórdias são um caso especial de irmandade em que a assistência se sobrepôs às demais funções. As Misericórdias geralmente eram fundadas por iniciativa da família real ou por membros da nobreza e altos dignitários eclesiásticos, usufruindo de diversos privilégios e atraindo membros das elites locais.

A confraria ou irmandade da Misericórdia possuía uma grande

\footnotetext{
${ }^{108}$ LOUSADA, Maria Alexandre. Espaços de sociabilidade em Lisboa. Lisboa: Dissertação de Doutorado em Geografia Humana apresentada à Faculdade de Letras da Universidade de Lisboa, 1995. p. 245-249.
} 
importância no Espírito Santo e em todo o mundo luso-brasileiro. Surgiu em Lisboa, no ano de 1498 e foi precursora de todas as congêneres nos domínios portugueses. As Irmandades da Misericórdia possuíam a obrigação de recolher e curar os enfermos pobres, acompanhar os culpados sem defesa aos tribunais, entregar dotes às donzelas "infelizes", auxiliar as viúvas pobres, recolher e educar os órfãos, dar pousada e socorro aos peregrinos necessitados e fazer prece e sepultura aos mortos. Geralmente quando se fundavam vilas e cidades nos domínios portugueses organizava-se a Irmandade da Misericórdia.

No Espírito Santo, a Santa Casa de Misericórdia foi fundada em 1545, sendo a segunda Misericórdia a ser criada na colônia. Com a expulsão dos Jesuítas no século XVIII, a Misericórdia do Espírito Santo perdeu os seus maiores colaboradores. O governador do Espírito Santo, Francisco Alberto Rubim (1812-1819) encontrou a Misericórdia sem recursos. A vista disso, Rubim encaminhou a D. João VI um requerimento de "lavradores e negociantes" de Vitória a fim de construírem, na vila, um hospital para atender aos enfermos pobres. A manutenção seria feita por contribuições retiradas de exportações dos portos de Vitória. Em 1818, foi dada a autorização para a criação de um hospital de caridade sob a inspeção da Misericórdia, localizado na fazenda Campinho, doada por D. Maria de Oliveira Subtil ${ }^{109}$.

Na década de 1830, José Francisco de Andrade e Almeida Monjardim e Dionízio Álvaro Rozendo encontraram-se nessa confraria. Monjardim foi escrivão interino na Provedoria da Irmandade, no período de 1829 a $1831^{110}$. Já no ano seguinte, Monjardim foi eleito membro da comissão incumbida da reforma do compromisso da Irmandade, instituição organizacional da qual Dionízio Álvaro Rozendo também participava. Em 1829, Rozendo escreveu o testa-

\footnotetext{
${ }^{109}$ BONICENHA, Walace. Devoção e caridade: As irmandades religiosas na cidade de Vitória. Vitória: Editora Multiplicidade. 2004. p. 118-123.

${ }^{110}$ SCHWAB, Affonso. A irmandade e a Santa Casa da Misericórdia do Espírito Santo. Vitória: Arquivo Público Estadual. 1979. p. 50-59.
} 
mento de Luiz Antônio da Silva, que deixou herança à instituição. Já em 1834, foi nomeado o escrivão da comissão da irmandade que tomaria as contas do ex-tesoureiro Capitão João Pinto Ribeiro de Seixas ${ }^{111}$. Monjardim e Rozendo, portanto, ocuparam importantes cargos dentro da Misericórdia e, sem dúvida, encontraram-se nos afazeres cotidianos da condução da confraria.

Para Maria Alexandre Lousada ${ }^{112}$, as irmandades constituem-se uma forma especial e muito antiga de sociabilidade. A ligação ao culto religioso conferia à irmandade um acrescido poder de vinculação entre seus membros. As irmandades promoviam o desenvolvimento de formas de convivência. Citando Caio Boschi, Maria Alexandre Lousada afirma que, na sociedade colonial brasileira, as reuniões das irmandades eram ocasiões também para debates e convivência social, além do caráter religioso. Essas reuniões geralmente aconteciam num espaço religioso: a sacristia da igreja onde a irmandade estava sediada, por exemplo. Nesse sentido, a Irmandade da Misericórdia também pode ser entendida enquanto um espaço de socialização política para os seus membros.

Outra instituição religiosa também foi local de encontro para Manoel da Siqueira e Sá Júnior e Ignácio Félis de Alvarenga Salles: a Ordem Nossa Senhora do Monte do Carmo. Já em 1819, João Clímaco de Alvarenga Rangel e Ignácio Félis de Alvarenga Sales compartilharam o momento de nomeação como subdiáconos, pelo Eclesiástico D. José Caetano da Silva ${ }^{113}$. É um evento que aponta para os encontros que os eclesiásticos tiveram dentro da instituição da igreja. Da mesma forma que a burocracia e as corporações militares eram locais que propiciavam a circulação e encontro dos personagens em questão, a igreja também foi um local favorável para o compartilhamento de valores e experiências.

Encontraram-se também dois deputados que tiveram entre

\footnotetext{
${ }^{111}$ SCHWAB, 1979. p. 47-59.

${ }^{112}$ LOUSADA, 1995. p. 245-258.

${ }^{113}$ SILVA, José Caetano da. Freguesia de Vitória. 1817-1818. Disponível em: <www.estacaocapixaba.com.br>. Acesso em: 14 fev. 2007.
} 
si uma aproximação por meio de um laço familiar. Em 1816, Francisco de Andrade e Almeida Monjardim tornou-se genro de Francisco Pinto Homem de Azevedo. Ou seja, quando Monjardim e Pinto Homem encontram-se no passo provincial, já eram eles unidos por laços familiares há 14 anos. Certamente isso contou para que esses dois homens tivessem um relacionamento político diferenciado dentro do parlamento.

Outro espaço de socialização, como demonstrado no organograma, foi a Câmara Municipal de Vitória. No final da década de 1820 e início da de 1830, quatro deputados se encontram nessa instituição política: Sebastião Vieira Machado, Manoel da Siqueira e Sá Júnior, Manoel Pinto Rangel e Silva e Manoel da Silva Maia. Nesse espaço, esses homens puderam vivenciar a experiência que se aproximava de um parlamento, apesar das limitações sofridas pelas câmaras municipais, como já visto. Passando juntos por essa experiência político-institucional puderam compartilhar valores e capacitações políticas.

O organograma também apresenta o encontro de dois deputados em uma instituição militar. Sebastião Vieira Machado e Manoel da Silva Maia participavam da Companhia dos Caçadores, no ano de 1813. Eram, portanto, companheiros de armas dentro de uma mesma instituição, compartilhando experiências e valores dentro da corporação militar.

\section{2 - MÚLTIPLAS TRAJETÓRIAS E UMA ELEIÇÃO}

As trajetórias dos deputados da primeira legislatura da Assembleia Provincial do Espírito Santo aproximavam-se em diversos pontos, com destaque para a ocupação de carreiras políticas antes de 1835 e para a proximidade em carreiras profissionais. É interessante notar como essas trajetórias refletiram no momento da eleição em 1834. Segundo a tabela abaixo, a distribuição de votos recebidos pelos deputados - na eleição de 1834 para a Assembleia Provincial 
= Figurões da terra : trajetórias e projetos políticos no Espírito Santo do Oitocentos -79

nos colégios eleitorais de Vitória e da Vila de Benevente -, de acordo com apuração da Câmara Municipal de Vitória ${ }^{114}$, ficou da seguinte forma:

TABELA 6 - APURAÇÃO DOS VOTOS PARA DEPUTADOS PROVINCIAIS DO ESPÍRITO SANTO - 1834

\begin{tabular}{l|c}
\multicolumn{1}{c|}{ DEPUTADOS ELEITOS } & VOTOS \\
\hline Luiz da Silva Alves de Azambuja Suzano & 62 \\
Francisco Pinto Homem de Azevedo & 61 \\
João Luiz da Fraga Loureiro & 61 \\
Manoel da Silva Maya & 50 \\
José de Barros Pimentel & 49 \\
Manoel Moraes Coutinho & 49 \\
Dionísyo Álvaro Rozendo & 42 \\
Manoel d' Assunção Pereira & 40 \\
José Francisco de Andrade e Almeida Monjardim & 38 \\
Ignácio Félis de Alvarenga Sales & 36 \\
João Clímaco de Alvarenga Rangel & 35 \\
Francisco Ribeiro Pinto & 35 \\
Manoel Pinto Rangel e Silva & 35 \\
Joaquim da Silva Caldas & 33 \\
Manoel da Siqueira e Sá Júnior & 33 \\
Miguel Rodrigues Batalha & 32 \\
Sebastião Vieira Machado & 32 \\
Ayres Vieira de Albuquerque Tovar & 32 \\
João Nepomuceno Gomes Bittencourt & 32 \\
Inácio Pereira Duarte Carneiro & 31 \\
\hline
\end{tabular}

Fonte: ARQUIVO DA ASSEMBLEIA LEGISLATIVA DO ESPÍRITO SANTO. Ata da apuração dos votos para Deputado Provincial dos colégios eleitorais de Vitória e Vila de Benevente. 1834.

\footnotetext{
${ }^{114}$ Em estatística de um ano antes, a província do Espírito Santo possuía uma população de 29.575 pessoas, dentre livres e escravos, sendo que 10.299, ou $35 \%$ do total, se concentrava nas vilas de Vitória e Benevente (MARQUES, Cezar Augusto. Dicionário Histórico, Geográfico e Estatístico da Província do Espírito Santo. Rio de Janeiro: Tipografia Nacional, 1878. p. 84-85).
} 
Numa primeira observação da tabela, é possível notar uma informação importante: os três mais votados possuem praticamente a mesma quantidade de votos, sendo que do terceiro mais votado para o quarto existe uma considerável distância de onze votos. Relacionando-se com esse dado está o histórico particular de cada um desses três primeiros colocados. Na ordem de apresentação da tabela, são as seguintes as ocupações desses personagens: O campeão de votos no referido colégio eleitoral (concentrador da esmagadora maioria dos eleitores provinciais), Luiz da Silva Alves de Azambuja Suzano, era um funcionário público que acumulara em sua carreira as funções de escriturário da fazenda (1811-1825) e de juiz de paz e de órfãos. Como político, foi secretário da Junta de Governo Provisório antes de 1835 e teve papel fundamental na independência. Foi ele quem, em mãos, felicitou D. Pedro em nome da província do Espírito Santo, além de ter exortado as câmaras baianas próximas do Espírito Santo a não apoiarem a causa do Brigadeiro Madeira, que por sua vez se opunha à causa independentista do Brasil. Desse modo, Azambuja, antes de se tornar deputado, teve uma trajetória profissional e política que o projetou dentro do Espírito Santo, fazendo-o ganhar destaque entre os cidadãos e tornar-se o deputado mais votado de 1834, deixando em segundo lugar um dos homens economicamente mais poderosos da província naquele momento.

Francisco Pinto Homem de Azevedo, segundo mais votado, teve um caminho em parte diferente do de Luiz da Silva Alves de Azambuja Suzano, mas que também lhe serviu como impulso para sua eleição de deputado. Homem de Azevedo já possuía como elemento de destaque ser um dos indivíduos mais ricos do Espírito Santo na primeira metade do oitocentos, embora o relevo desse personagem não seja decorrente apenas da posse de sua extensa fortuna. Homem de Azevedo transformou seu patrimônio material em patrimônio simbólico por meio do financiamento de obras de interesse do Espírito Santo, como a ponte de Maruípe. Graças a essas obras materiais financiadas com dinheiro particular, Homem de Azevedo se tornou um dos homens de maior projeção regional. Transformando 
parte do seu capital objetivo (bens materiais) em capital simbólico, garantiu para si prestígio, fama e reputação $0^{115}$. Sua projeção ultrapassou o âmbito regional, tanto que em 1825 recebeu das mãos de D. Pedro I o hábito de Cavaleiro da Ordem de Cristo. Como cavaleiro dessa ordem, Homem de Azevedo teve outro importante acréscimo ao seu patrimônio simbólico ou pessoal.

Tornar-se cavaleiro da Ordem de Cristo tinha um valor importantíssimo no início do Império do Brasil. A Ordem teve sua origem em Portugal. Foi fundada pelo Rei D. Dinis, com o nome de Religião Militar de Cristo, no dia quatorze de agosto de 1318. A bula da instituição dessa corporação foi expedida pelo Papa D. João XXII, em quatorze de março de 1319. O Rei português doou para essa ordem a Vila e Fortaleza de Cristo Marim no Algarve, mandando instalar ali o convento da Ordem, um ponto que permitia fazer guerra aos mouros de Marrocos e Granada.

Na verdade, a Ordem de Cristo era uma reconstituição da Ordem do Templo, ingressando nela os antigos templários de Portugal, sendo seu primeiro Grão-Mestre D. Gil Martins. Em ordem decrescente, as dignidades da Ordem de Cristo eram as seguintes: Mestre, Prior-Mor, Comendador-Mor, Claveiro, Sacristão-Mor, Alferes ${ }^{116}$. Em Portugal, havia outras ordens, como a de São Bento de Aviz e São Tiago da Espada. Em virtude disso, quando D. João VI chegou ao Brasil, criou o Tribunal da Mesa da Consciência e Ordens, para a regulação das ordens em território brasileiro. Depois da Independência, D. Pedro criou outras ordens no Brasil, sendo elas a do Cruzeiro (criada em 1ำ de dezembro de 1822), a de D. Pedro I (criada em dezesseis de abril de 1826) e a da Rosa (criada em dezessete de outubro de 1829). Além dessas, o primeiro imperador manteve no Brasil uma Versão da Ordem de Cristo ${ }^{117}$.

\footnotetext{
${ }^{115}$ BOURDIEU, Pierre. O Poder Simbólico. Rio de Janeiro: Bertrand Brasil, 2006. p. 15, 134, 135.

${ }^{116}$ MELO, Olímpio de. Ordens militares portuguesas e outras condecorações. Imprensa Nacional de Lisboa. 1922. p. 23.

${ }^{117}$ POLIANO, Luiz Marques. Ordens Honoríficas do Brasil. Rio de Janeiro: Imprensa Nacional. 1943. p. 64-124.
} 
Francisco Pinto Homem de Azevedo, portanto, foi agraciado com essa condecoração representante de uma tradição secular dentro do Império Português, tanto que foi a única ordem portuguesa preservada no pós-independência brasileiro. Como Cavaleiro de Cristo, ele era considerado pela corte um dos indivíduos de maior destaque da província do Espírito Santo, e tornou-se um dos seus cidadãos mais importantes.

Além de sua riqueza material e de seu hábito de Cavaleiro de Cristo, Francisco Pinto Homem de Azevedo também encaminhou uma destacada carreira de militar. Em 1814, constava como Coronel do Estado Maior; já em 1829, estava como Capitão-Mor do Espírito Santo; no período de 1807 a 1825, por sua vez, como Capitão-Mor das Ordenanças de Vitória ${ }^{118}$.

Desse modo, ascendeu a postos de comando da província antes de 1835, podendo conhecer as demandas provinciais e as conturbações pelas quais passava o Espírito Santo. Homem de Azevedo, neste trabalho, foi enquadrado como militar, em virtude de ele aparecer mais vezes nas fontes sob essa classificação. Entretanto, é outro caso de deputado que desempenhou mais de uma classe de funções antes de 1835. Ele também foi encontrado no período de 1811 a 1814 como Juiz de Órfãos. Percebe-se, desse modo, que Homem de Azevedo não teve a corporação militar como seu único meio de construir suas relações de sociabilidade e interdependência. A multiplicidade de relacionamentos e círculos sociais permitiu-lhe um destaque, conduzindo-o até o Paço Provincial em 1835.

Enquanto político, Francisco Pinto Homem de Azevedo também constituiu uma carreira antes de 1835. Foi vereador da Câmara Municipal de Vitória, um dos eleitores do representante da Província do Espírito Santo nas Cortes de Lisboa (1821), membro do Conselho Provincial do Espírito Santo. Em 1828, como membro do Conselho de Governo, assumiu interinamente a Presidência da

\footnotetext{
${ }^{118}$ BIBLIOTECA NACIONAL. Documento: C-0355, 006. Requerimento encaminhado ao ministério do império solicitando a mercê da Ordem Cristo. 1823-1825.
} 
Província, por causa de viagem do presidente titular Ignácio Accioli de Vasconcelos. Em 1830, ainda era membro do Conselho Provincial de Governo, assumindo, por ser vice, a presidência da província no mesmo ano. Nesses termos, destacou-se também enquanto político, tendo atuado na administração da Capitania e na Câmara Municipal, experiências que lhe deram habilidades políticas e notoriedade enquanto homem público no Espírito Santo.

Por fim, o terceiro deputado mais votado foi João Luiz da Fraga Loureiro. O caso desse padre é emblemático. Era escritor de artigos e sermões ${ }^{119}$, além de ser profundo conhecedor de latim e poeta. Suas primeiras poesias foram escritas quando tinha ainda vinte anos, sendo publicadas em jornais ${ }^{120}$. João Luiz da Fraga Loureiro era um poeta popular e famoso nas festas em louvor a São Benedito $^{121}$. Em 1825, então com 20 anos, seguiu em viagem para a Corte com o objetivo de ampliar seus estudos, graças a indicação obtida pelo pai, o Sargento-Mor Loureiro (homem influente da época, como informa Daemon ${ }^{122}$ ), da parte do Presidente da Província, Accioli de Vasconcelos, ao Ministro do Império, Luiz de Carvalho e Mello, em reconhecimento ao talento do jovem Fraga Loureiro. Por meio desse importante contato, o poeta capixaba possivelmente foi apresentado a S. M. o Imperador a fim de ser enviado para a França, onde iria concluir seus estudos em alguma universidade. Toda a despesa correria por conta do Sargento-Mor Loureiro. Após passagem pela Europa e ordenação no Rio de Janeiro, certamente o nível intelectual desse sacerdote destacava-se em meio a uma sociedade de analfabetos. Ressalte-se que a educação era uma marca distintiva da elite política imperial ${ }^{123}$. Segundo Afonso Cláudio ${ }^{124}$,

\footnotetext{
${ }^{119}$ CLAÚDIO, Afonso. História da Literatura Espírito Santense. Rio de Janeiro: Biblioteca reprográfica xerox, 1981. p. 117.

${ }^{120}$ ELTON, Elmo. Poetas do Espírito Santo. Vitória. 1982. p. 20.

${ }^{121}$ Disponível em: <www.poetas.capixabas.com.br>. Acesso em: 11 ago. 2005

${ }^{122}$ DAEMON, Basílio Carvalho. Província do Espírito Santo. Vitória. 1879. p. 272.

${ }^{123}$ CARVALHO, 1981. p. 64.

${ }^{124}$ CLAÚDIO, 1981. p. 119.
} 
[...] A tradição sagrou Fraga Loureiro poeta popular e com isto fez-lhe justiça; nas festas de natalícios, nas manifestações aos altos funcionários, aos cidadãos de prestígio do país ou da província, como nas festas religiosas, cabia-lhe sempre interpretar os sentimentos dos manifestantes e devotos [...]

Percebe-se que o desempenho dos papéis sociais de líder religioso e poeta permitiu a Fraga Loureiro acessar diversos ambientes sociais, entre as autoridades de sua época (funcionários e cidadãos de prestígio) e as camadas sociais de menos recursos. Evidentemente, esse intenso trânsito pelos círculos de poder e por outros nichos da sociedade daquele tempo permitiu a Loureiro inserir-se como figura fundamental no quadro político do Espírito Santo, que participava da fundação do recente Estado Brasileiro por meio da organização política da nova província imperial e da Assembleia Legislativa. Facilitou a ascensão de Loureiro na cena política o fato de possuir passagem (em seu ofício espiritual) por diferentes paróquias: Santa Cruz, Carapina e Vila do Espírito Santo, ocupando ainda o cargo de Arcipreste e Vigário da Vara da Capital. Supõe-se diante dessa viva presença social como padre e intelectual, locomovendo-se entre diversos espaços sociais, que João Luiz da Fraga Loureiro tenha nesses contatos construído laços de solidariedade fundamentais para ser considerado, pelos eleitores, no momento da escolha dos deputados provinciais, um indivíduo de elevadas qualidades para ocupar a função de deputado.

A observação dessa eleição também trouxe o seguinte dado: os três deputados mais votados na eleição de 1834 para a Assembleia do Espírito Santo representavam as três categorias ocupacionais mais encontradas entre os deputados da primeira legislatura: padres, funcionários públicos e militares. Outro detalhe importante é que o mais votado, Luiz da Silva Alves de Azambuja Suzano, pertencia justamente ao grupo com menor número de componentes, os funcionários públicos. Ou seja, apesar de terem sido encontrados apenas três deputados que eram funcionários públicos de carreira, o deputado mais votado pertencia a essa classe. 
Outro fator de destaque é a continuidade da carreira política do Deputado José Francisco de Andrade e Almeida Monjardim até a legislatura de 1880/1881, além de ter ocupado o cargo de Presidente da Província. No entanto, ele não esteve entre os mais votados em 1834, tendo sido o nono na classificação geral. Apesar de ter o sogro Francisco Pinto Homem de Azevedo como o segundo mais votado nessa eleição, Monjardim ainda não havia angariado capital político suficiente para poder ser um dos primeiros na eleição.

Entretanto, dentro das modulações da política, Monjardim conseguiu, no contexto após 1835, alcançar o lugar de um dos políticos mais importantes do Espírito Santo, tendo deixado um patrimônio político à sua família, com herdeiros ocupando importantes cargos políticos no Espírito Santo até o início do período republicano $^{125}$.

\section{3 - TRAJETÓRIAS APÓS 1837}

Se, nos momentos anteriores a 1835, o Espírito Santo presenciou a formação de uma elite política regional por meio da ocupação de postos institucionais nos quais se encontraram e compartilharam sua experiência política anterior e, se, por isso, puderam conduzir o novo processo institucional regencial, a realidade e projeção política dessa elite pode ser confirmada pela localização de um grupo considerável entre esses deputados que tenha se perpetuado em um tempo posterior considerável - tempo este obviamente limitado pela finitude biológica de cada um desses indivíduos - para que pudessem realizar conjuntamente a organização de uma nova ordem política local e deixassem um legado político coletivo.

\footnotetext{
${ }^{125}$ Alpheu Adelpho, filho de Monjardim, foi deputado provincial de 1864 a 1869, governou o Espírito Santo em período dentro do último quartel do século dezenove e no início do século XX. José Francisco, neto de Monjardim, foi deputado estadual nas legislaturas de 1898-1900. Manoel Silvino, neto de Monjardim, deputado provincial nos períodos de 1904-1906 e 19101918. Argeu Hortêncio, neto de Monjardim, deputado provincial na legislatura de 1922-1924 e governador no período de 1904-1905.
} 
Para tal confirmação, computou-se a presença dos deputados eleitos da legislatura 1835-1837 em legislaturas seguintes. Com a observação feita, descobriu-se que, até o ano de 1881, tem-se a presença de deputados que atuaram na primeira legislatura. A partir desses dados, desenvolveu-se o seguinte gráfico (FIGURA 4):

FIGURA 4

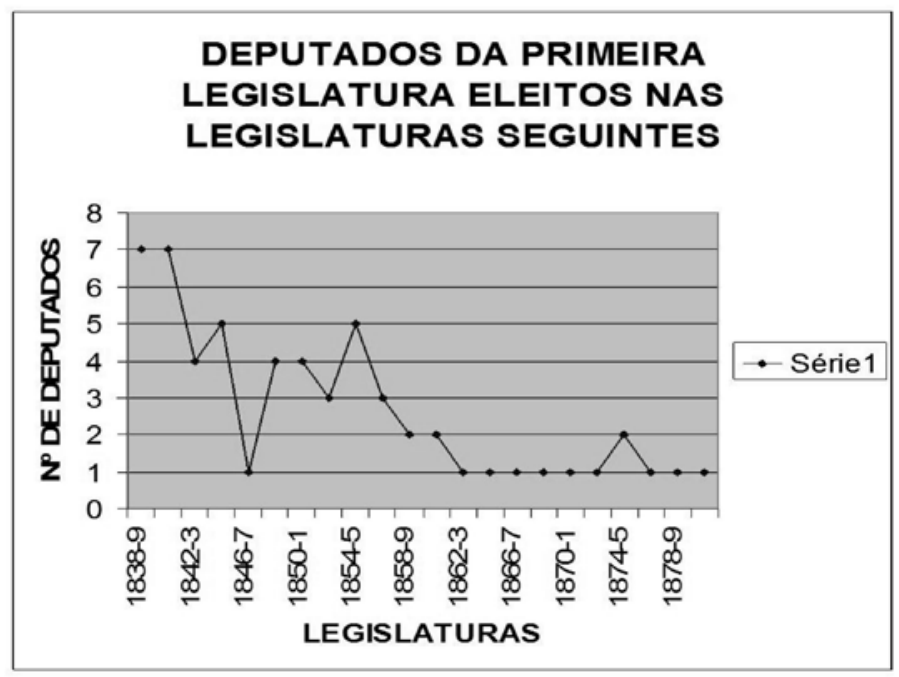

A partir do gráfico, percebe-se uma variação no número de deputados da primeira legislatura que conseguiram se eleger nas seguintes. Em primeiro lugar, nota-se que, nos quatro anos seguintes à primeira legislatura, houve uma constante de sete deputados presentes na casa de leis em questão. De 1842 a 1843, por sua vez, o número de reeleitos caiu para quatro, subindo para cinco na legislatura seguinte. Na legislatura de 1846-7 houve uma queda abrupta para apenas um deputado da primeira legislatura reeleito, para nos quatro anos seguintes haver uma recuperação, subindo para quatro o número de deputados da primeira legislatura reeleitos. $\mathrm{Na}$ legislatura seguinte, ocorreu uma pequena queda, para três depu- 
tados, para na legislatura de 1854-5 haver uma considerável recuperação, para cinco deputados, sendo que nas legislaturas até o final do período esses números não ultrapassaram o de três deputados reeleitos, número encontrado apenas na legislatura de 1856-7. De 1862 até 1881 , foi quase constante o número de apenas um deputado da primeira legislatura reeleito, com a exceção da legislatura de 1874-5, quando se observa que dois deputados da primeira legislatura foram reeleitos.

Portanto, apreende-se que, até meados do século dezenove (legislatura 1854-55), a presença de deputados da primeira legislatura em períodos posteriores variou entre sete e cinco. Já na segunda metade do oitocentos a queda se tornou mais abrupta. Dentre esses reeleitos, entretanto, nem todos conseguiram se reeleger constantemente, havendo um revezamento.

Como apresentado de início, essa quantificação tem por finalidade buscar saber se, em algum período, houve uma perpetuação de pelo menos parte do grupo de 1835 em legislaturas seguintes da Assembleia do Espírito Santo. Se os números anteriormente apontados forem transpostos para uma dimensão de porcentagem, uma realidade esclarecedora se delineia:

TABELA 7 - PORCENTAGENS DE DEPUTADOS DE 1835 PRESENTES

EM LEGISLATURAS APÓS 1837

\begin{tabular}{c|c} 
LEGISLATURAS & PORCENTAGENS \\
\hline $1838-9$ & 35 \\
$1840-1$ & 35 \\
$1842-3$ & 20 \\
$1844-5$ & 25 \\
$1846-7$ & 5 \\
$1848-9$ & 20 \\
$1850-1$ & 20 \\
$1852-3$ & 15
\end{tabular}




\begin{tabular}{l|c}
$1854-5$ & 25 \\
$1856-7$ & 15 \\
$1858-9$ & 10 \\
$1860-1$ & 10 \\
$1862-3$ & 5 \\
$1864-5$ & 5 \\
$1866-7$ & 5 \\
$1868-9$ & 5 \\
$1870-1$ & 5 \\
$1872-3$ & 5 \\
$1874-5$ & 10 \\
$1876-7$ & 5 \\
$1878-9$ & 5 \\
$1880-1$ & 5 \\
\hline
\end{tabular}

Por meio dessa quantificação, é possível chegar a algumas conclusões. Percebe-se, a princípio, que, até o ano de 1861, tem-se a presença considerável de membros da primeira legislatura que continuam atuantes no legislativo provincial do Espírito Santo. A porcentagem dessa presença varia de 35\% (pico encontrado nos anos 1838 a 1841), ao seu menor número na legislatura de 1846-1847 (5\%). Desse modo, conclui-se que, até 1861 , o grupo político consolidado em 1835 se faz presente em legislaturas seguintes por meio de alguns deputados que expandem suas carreiras políticas além do período de consolidação legislativa provincial. Pode-se dizer que a presença desse grupo se faz sentir até o início da década de 1860, quando o número dos deputados provenientes da primeira legislatura chega a $10 \%$ do parlamento, caindo posteriormente para uma constante de $5 \%$, constante essa só quebrada na legislatura de 1874-5, quando novamente a percentagem sobe para $10 \%$.

Entretanto, dentre esses deputados reeleitos existem alguns destaques, pois conseguiram manter-se mais constantemente no poder e, assim, consolidar uma carreira política de forma mais perene, conduzindo o legado político da primeira legislatura dentro do parlamento. Três deles, contudo, destacam-se por se manterem 
ininterruptamente no poder por oito anos - de 1835 a 1843 (quatro legislaturas). São eles: João Luiz da Fraga Loureiro, Dionízio Álvaro Rozendo, José Francisco de Andrade e Almeida Monjardim.

Além disso, esses deputados são localizados em outras legislaturas. João Luiz da Fraga Loureiro, por exemplo, ainda foi deputado nos períodos de 1844-45, 1848-51 e 1854-55. Dionísio Álvaro Resendo, por sua vez, também teve sua vida política expandida. Depois de 1843, foi deputado ainda nos períodos de 1848-49, 1850-51, 18541857, 1860-1863, 1870-1877. Sendo assim, Dionízio Álvaro Rozendo se manteve ativo na vida política até o último quartel do século dezenove.

O notório destaque, certamente, vai para José Francisco de Andrade e Almeida Monjardim. Monjardim foi eleito, além de 1835, para mais quatorze legislaturas, estando no parlamento do Espírito Santo até o ano de 1881. Como visto anteriormente, Monjardim possuiu uma carreira militar importante para o Espírito Santo, sendo também filho de militar. Mas, além de sua atuação no meio militar, esse indivíduo circulou por outras dimensões sociais da realidade capixaba antes de ter uma carreira política intensa de deputado provincial. Como político, antes de 1830, Monjardim ocupou importantes cargos de liderança na província. Em 1822, estava entre os componentes da Junta de Governo Provisório. Posteriormente, quando se estabeleceu o Conselho de Governo na província, Monjardim teve intensa participação como conselheiro. No período de 12 de março de 1830 a 27 de abril de 1832, assumiu por quatro vezes o governo interino da província do Espírito Santo. Em 1822, também foi encontrado como vereador da Câmara Municipal de Vitória. Além disso, Monjardim também esteve como membro do Conselho Geral de Província, no período de 1830-1831. Sua participação também se fez presente em momentos fulcrais para a história nacional. 
de sagração e coroação de D. Pedro I, cabendo-lhe a honra e o privilégio de empunhar uma das varas do pálio sob o qual o Imperador fez o trajeto do paço à Capela Imperial. Esse episódio histórico está documentado na tela do pintor francês Jean Baptiste Debret ${ }^{126}$.

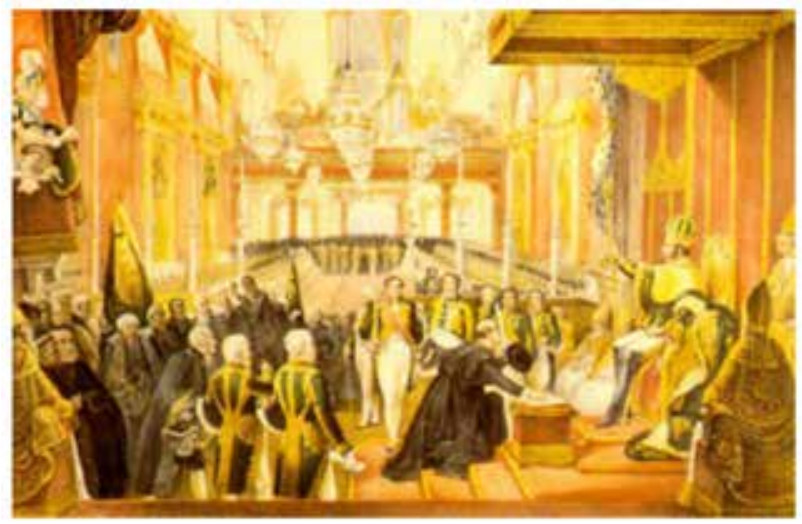

FIGURA 5 - DEBRET, Jean Baptiste. Coroação de Dom Pedro, Imperador do Brasil. Viagem Pitoresca e História pelo Brasil. Disponível em: <www.bibvirt.futuro.usp.br >. Acesso em: 24 mar. 2008.

Percebe-se, dessa maneira, que Monjardim ocupou todos os cargos políticos possíveis em nível provincial, além de ter tido acesso às esferas centrais de poder no Brasil. Supõe-se que essa circulação prévia no meio político imperial serviu para que ele se tornasse uma figura de projeção na política do Espírito Santo.

Monjardim tinha como um dos seus círculos sociais o pertencimento à Maçonaria. Mas participava de outro círculo social, também muito importante à época. Esteve como um dos membros da Irmandade da Misericórdia do Espírito Santo, sendo escrivão dessa organização em 1829. Já em 1832, foi eleito participante da comissão que reformaria o compromisso dessa irmandade. Percebe-se, portanto, a importância para Monjardim do pertencimento a esse círculo social. Participando de uma irmandade de caridade, não apenas

\footnotetext{
${ }^{126}$ MONJARDIM, Leonardo Passos. História Política da família Monjardim. Vitória: Lei Rubem Braga, 2003. p. 43
} 
teve acesso a muitas das demandas do Espírito Santo, mas também se tornou conhecido de outros figurões importantes da província, muitos deles eleitores dentro do sistema eleitoral imperial.

Monjardim também teve um respaldo em sua família para se projetar enquanto grande homem da política local. o pai, Ignácio João Monjardim, era um português que também ingressou na carreira militar. Em 1782 foi enviado ao Brasil para tomar posse da capitania do Espírito Santo. Por serviços prestados ao Império Português, recebeu importantes títulos, por exemplo, comendador da Ordem de Cristo, e comendador da Ordem da Rosa ${ }^{127}$. Sendo assim, o futuro deputado Monjardim teve como herança familiar uma trajetória política e militar paterna que o preparou e o projetou como um dos mais notórios políticos locais.

Além de ter por pai um importante militar, nobre e governador da capitania do Espírito Santo, Monjardim também era genro do poderoso Francisco Pinto Homem de Azevedo, homem de vasta influência na província, por sua posição política e riqueza material, como já demonstrado. Monjardim casou-se aos 19 anos com Ana Francisca Maria da Penha Benedita Homem de Azevedo ${ }^{128}$. Dessa união, Monjardim não apenas herdou o casarão setecentista que viria a ser conhecido como Solar Monjardim, mas também recebeu como patrimônio imaterial o fato de ser genro de um dos homens mais importantes do Espírito Santo do início do XIX. Homem de Azevedo foi um dos notáveis do seu tempo. Destacou-se por sua riqueza material, influência por meio da construção de obras para o Espírito Santo e participação em diversos cargos públicos, além de também ser um importante militar. Na década de 1830, sogro e genro encontraram-se no passo provincial, agora não apenas como integrantes do mesmo círculo familiar, mas também da casa de leis. Por outro lado, os laços familiares que os uniam certamente influíam dentro desse novo círculo de socialização.

\footnotetext{
${ }^{127}$ MONJARDIM, 2003, p. 25-26.

${ }^{128}$ MONJARDIM, 2003, p. 46
} 
Além do patrimônio simbólico alcançado por sua carreira militar, política e laços familiares, antes de 1835 Monjardim foi congratulado com o hábito de Cavaleiro da Ordem do Cruzeiro pelo Decreto de primeiro de dezembro de 1822. Essa congratulação fora feita num dos dias mais importantes do primeiro reinado: a coroação de D. Pedro I. Monjardim estava entre os primeiros cidadãos do Império a serem congratulados por essa ordem. A Ordem do Cruzeiro fora uma das ordens criadas por D. Pedro no Brasil independente. Além do Cruzeiro, D. Pedro criou as ordens de Pedro I e da Rosa. A inclusão na Ordem do Cruzeiro era dada aos que tivessem se destacado no serviço militar, civil ou científico. Podia ser dada a nacionais ou estrangeiros, sendo que D. Pedro I era seu Grão-Mestre. Os membros da Ordem do Cruzeiro possuíam os mesmos privilégios dos da Ordem de Cristo $^{129}$. Monjardim, portanto, foi congratulado por sua atuação militar, recebendo o hábito de cavaleiro da Ordem do Cruzeiro.

O recebimento da Ordem do Cruzeiro por Monjardim equivalia ao recebimento de um título. O título constitui-se num capital simbólico garantido, social e juridicamente, pois traz uma espécie de nobreza que promove um reconhecimento por um amplo grupo ${ }^{130}$. Nesses termos, Monjardim destacou-se no Espírito Santo por ser um dos que estiveram presentes na coroação de D. Pedro, não apenas sendo um daqueles que "[...] empunhou uma das varas do pálio sob o qual o Imperador fez o trajeto do paço à Capela Imperial [...]”, mas também sendo, nessa data, condecorado como um dos cavaleiros de Vossa Majestade. Certamente, quando Monjardim voltou para o Espírito Santo após essa condecoração, não foi recebido como antes pelos seus futuros colegas de parlamento, uma vez que nesse momento voltava como um daqueles que simbolicamente lançou as bases do trono de D. Pedro I, projeto que uniria em parte a elite política do Espírito Santo.

\footnotetext{
129 . POLIANO, Luiz Marques. Ordens Honoríficas do Brasil. Rio de Janeiro: Imprensa Nacional. 1943. p. 64-107.

${ }^{130}$ BOURDIEU, Pierre. O Poder Simbólico. Rio de Janeiro: Bertrand Brasil, 2006. p. 148
} 
Desse modo, percebe-se que essas três figuras, João Luiz da Fraga Loureiro, Dionísio Álvaro Resendo e José Francisco de Andrade e Almeida Monjardim, destacaram-se como o trio que levou adiante o legado da primeira geração de deputados da Assembleia do Espírito Santo. Certamente esse legado também foi deixado por outros deputados que conviveram com os primeiros componentes do legislativo em momentos posteriores a 1837. Entretanto, o espaço deste trabalho não permite uma análise desse porte. Tentou-se, desse modo, centrar-se nas biografias desses primeiros deputados e nas trajetórias políticas que desenvolveram. 


\section{4 - VOZES NO PAÇO}

Até agora, este trabalho concentrou-se naquilo que se tem chamado de elite política regional. Um grupo que, conforme apresentado, forjou-se em princípios do oitocentos e dominou a cena política do Espírito Santo até, pelo menos, meados do século XIX. No capítulo primeiro, a título de contextualização, mostrou-se um pouco da realidade dessa província. Uma província que passou por conturbações políticas no início do século dezenove, e que passava por duros problemas socioeconômicos. A elite política, por sua vez, tentou resolver esses problemas em consonância com as trajetórias sociopolíticas traçadas anteriormente pelos indivíduos que a compunham. As falas dos Deputados, por sua vez, são um importante testemunho daquilo que se passava no Espírito Santo. Desse modo, este capítulo se dedicará ao estudo de como eram desenvolvidos os canais de comunicação entre a elite política regional e a província do Espírito Santo.

Em princípio, é necessário observar o quadro que se desenhava para a elite política regional em questão. A monarquia implantada no Brasil fora inspirada no modelo constitucionalista inglês. Entretanto, um dos principais quesitos do constitucionalismo está na existência de um governo representativo baseado no voto de cida- 
dãos ${ }^{131}$. No caso brasileiro, ficavam fora da classificação de "cidadãos" as mulheres, os escravos e os com renda inferior a 100 mil réis. As eleições aconteciam em dois turnos. No primeiro, os votantes escolhiam os eleitores, que deveriam ter renda mínima de $200 \mathrm{mil}$ réis, os quais, por sua vez, elegiam deputados e senadores. Esse critério eleitoral foi o mesmo utilizado para a eleição dos deputados provinciais. Desse modo, percebe-se de início o destaque social para aqueles que ocupavam o paço provincial. Era um grupo que se destacava dos demais por sua riqueza, o que a eleição censitária e a descoberta de algumas fortunas particulares demonstram. Entretanto, fica perceptível que a distinção dessa elite política também era de caráter institucional. Eram homens de longas trajetórias políticas, além de terem ocupado importantes cargos de destaque para a localidade.

Apesar do destaque em diversas ocupações, essa elite tinha, enquanto possuidora do poder institucional local, de se comunicar com a população provincial. Não apenas com os demais homens notórios de seu tempo, mas também com setores menos abastados. Dificuldades estruturais tinham que ser resolvidas, sendo que a elite, materializada na Assembleia Legislativa Provincial, teria que sanar essas dificuldades, até por uma questão de legitimação da importância da existência da corporação do parlamento provincial.

Assim, as falas dos deputados demonstram a materialização de muitos interesses locais dentro do parlamento, locus institucional do poder da elite local. Temas administrativos, financeiros, ligados a segurança, escravos fugidos e também relativos ao comércio aparecem como pautas.

É interessante, neste ponto, localizar de onde partiam essas demandas para que chegassem ao parlamento. Um dos argumentos deste trabalho é o de que a elite política que toma posse da Assembleia Legislativa, em 1835, estava preparada por suas carreiras,

${ }^{131}$. CARVALHo, José Murilo de. Cidadania no Brasil: o longo caminho. 6. ed. Rio de Janeiro: Civilização brasileira, 2004. p. 29. 
formação e experiências para receber e processar, dentro dos limites institucionais, as demandas nascidas da província do Espírito Santo. Entretanto, trata-se aqui de entender como se dava o contato dos deputados com os grupos mais interessados na resolução dessas demandas, grupos esses que não estavam presentes dentro do parlamento.

\section{1 - A PROVÍNCIA CLAMA}

\subsection{1 - Um cenário nada promissor}

A realidade que os deputados do Espírito Santo encontraram em 1835 era, no mínimo, desafiadora. Se o relatório do Presidente de Província Manoel José Pires da Silva Pontes ao Conselho Geral de Província, do ano de 1833 (portanto dois anos antes da instalação da Assembleia Legislativa Provincial) for tomado literalmente, confirma-se o grande trabalho que a elite política teria pela frente. Esse presidente via problemas em diversas áreas. No quesito militar, por exemplo, a situação era degradante. As forças defensivas da província estavam em calamitosa situação. A Companhia de Permanentes, que deveria ter cem praças,

[...] nunca apresentou mais de sessenta no estado efetivo [...] uma sessão de cavalaria mal organizada, sem instrução, nem fardamento, e que, portanto, mal mal poderia preencher os fins de sua instituição [...] uma fortaleza desarmada pela decomposição do carretame, outra completamente desarmada em conseqüência da sedição militar $[. . .]^{132}$

Silva Pontes ainda reclamava da situação política que encontrou

\footnotetext{
${ }^{132}$ ARQUIVO DA ASSEMBLEIA LEGISLATIVA DO ESPÍRITO SANTO. Relatório de Manoel Pires da Silva Pontes ao Conselho Geral. 1833.
} 
no momento de sua posse. Segundo ele, encontrou "[...] Câmaras Municipais parte compostas de membros que entraram forçados, parte consistindo de cidadãos néscios, posto que probos, juízes de paz honrados, mas quase sem noção de jurisprudência, e sem assessores $[. . .]^{\prime 133}$.

Para Silva Pontes, a agricultura também não ia muito bem. Segundo ele, “[...] quase todos os lavradores da Província não deduzem outro direito às suas terras, que a posse antiga, fonte perene de discórdias [...]". Além disso, outros graves problemas atordoavam a agricultura do Espírito Santo: “[...] A mania de adquirir terrenos desproporcionados, e o abandono da terra cultivada. Alegam os lavradores, que assim obram, que a terra depois de duas ou três colheitas torna-se estéril, e um campo para formigas [...]"134.

Até a vida cotidiana da província foi desqualificada por esse governante. Para Silva Pontes,

[...] As comodidades a que os homens reunidos têm direito, não passam nesta cidade [Vitória] da casa de açougue, da banca do peixe, e de dois chafarizes! Faltam-lhes casas para o mercado da farinha, grãos e legumes; não há logradouro público, nem campo onde descansem as rezes, que se destinem ao talho, nem curral [...]; faltam aos vizinhos, e forasteiros [...] estalagens, e cavalherices, nem há prados, que dêem erva para cavalos de argola!

As vilas de Guarapary, Benevente e Itapemirim, que não possuem as cisternas precisas, muito têm sofrido este ano em conseqüência da seca. [...] $]^{135}$

A saúde, por sua vez, também não ia nada bem. O Hospital Casa de Misericórdia “[...] marcha a passos agigantados para a dissolução [...]”. Para Silva Pontes, a causa disso estava nos “[...] estatutos feitos

\footnotetext{
${ }^{133}$ ARQUIVO DA ASSEMBLEIA LEGISLATIVA DO ESPÍRITO SANTO. Relatório de Manoel Pires da Silva Pontes ao Conselho Geral. 1833.

${ }^{134}$ ARQUIVO DA ASSEMBLEIA LEGISLATIVA DO ESPÍRITO SANTO. Relatório de Manoel Pires da Silva Pontes ao Conselho Geral. 1833.

${ }^{135}$ ARQUIVO DA ASSEMBLEIA LEGISLATIVA DO ESPÍRITO SANTO. Relatório de Manoel Pires da Silva Pontes ao Conselho Geral. 1833
} 
na antiga metrópole, e fundados em alguns princípios que caducaram na presença da Constituição [...]"136.

\subsection{2 - Os Deputados e os desafios locais}

De acordo com esse relato, a situação da Província do Espírito Santo, no limiar da instalação da Assembleia Legislativa Provincial, não era das melhores. O relatório de onde se extraíram as informações das linhas acima fora direcionado ao Conselho Geral de Província, estabelecido pela constituição de 1824, conselho sem condições de legislar, mas que podia criar projetos de lei e realizava uma certa fiscalização sobre o presidente de província. Nesse sentido, o relatório não era direcionado a alguém que estava longe da realidade provincial, e sim para pessoas inseridas na realidade local, pertencentes à elite política regional. Portanto, não seria de grande eficácia se Silva Pontes, por algum motivo, fantasiasse demais a realidade do Espírito Santo no início da década de 1830.

Isso posto, presume-se que a realidade encontrada pela elite política do Espírito Santo em 1835 era a de um contexto em que demandas econômicas e sociais deveriam ser atendidas. Como estava no papel de ocupante do parlamento, essa elite deveria, naquele momento, compartilhar com o Presidente da Província o papel de responsável principal pela resolução das demandas que brotavam de diversas regiões da Província. A elite que se consolidava em 1835 teria que enfrentar diversos desafios, os quais, a partir daquele momento, seriam processados dentro de uma ordem parlamentar.

Conforme apresentado pelo relatório de Silva Pontes, dificuldades militares, agrícolas, de saúde pública e cotidianas assolavam o Espírito Santo. Outras fontes atestam a situação desafiadora no momento da instalação da Assembleia Legislativa. De acordo com

\footnotetext{
${ }^{136}$. ARQUIVO DA ASSEMBLEIA LEGISLATIVA DO ESPÍRITO SANTO. Relatório de Manoel Pires da Silva Pontes ao Conselho Geral. 1833.
} 
Daemon, nos anos de 1833 e 1834 o Espírito Santo foi assolado por uma seca $^{137}$

[...] que destruiu quase todas as plantações, faltando à população água e mantimentos para a sua subsistência, resultando disso penúria e reclamações [...] o Capitão Domingos Rodrigues Souto expôs à venda, nesse tempo, a farinha que tinha para embarcar, distribuindo grátis pelos indigentes parte dela; José Rodrigues Saraiva e Manoel Alves da Cruz Rios desembarcaram seus carregamentos e também os expuseram à venda, pelo que foram louvados pelo Conselho do Governo, que ainda deprecou para São Mateus, a fim de ser remetida para aqui toda farinha que se tivesse de embarcar [...] continuando a seca [em 1834] que já trazia penúria às localidades de Nova Almeida, Serra, Vitória, Cariacica, Viana, Queimado, Espírito Santo, Guarapari, Benevente e Itapemirim, são no dia primeiro de março deste ano nomeadas pelo conselho diversas comissões para agenciarem donativos, sendo eleitos na capital os Juízes de direito, Municipal e de Paz, pedindo além disso providências e recursos à regência [...]

Diante dessas amostras, tem-se o panorama de que o grupo político instalado no poder provincial possuía muito trabalho pela frente. Cabe agora analisar se essa elite política estava aberta para receber e processar essas demandas regionais. Tentou-se provar, no decorrer deste trabalho, que a capacitação dessa elite vinha de sua ocupação nas carreiras militares, burocráticas e clericais, além da passagem por cargos político-institucionais antes de 1835 . Nesse processo, esse grupo acumulou experiências e conhecimentos valiosos para ocupar o poder e exercê-lo. Entretanto, para se manter no poder institucional, essa elite teria que demonstrar, diante do governo central e da população provincial do Espírito Santo, sua capacidade como ocupante de uma instituição parlamentar.

Uma questão inicial e prioritária para essa análise é a localização de quem eram os demandantes à Assembleia Provincial.

\footnotetext{
${ }^{137}$ DAEMON, Basílio Carvalho. Província do Espírito Santo: sua descoberta, história cronológica, sinopse e estatística. Vitória: O Espírito-santense, 1879. Disponível em: <www.estacaocapixaba.com.br>. Acesso em: 23 ago. 2007.
} 
Numa afirmação preliminar, poder-se-ia defender que os demandantes seriam grupos que, apesar de não estarem no parlamento, também possuíam prestígio na vida social do Espírito Santo. No caso, homens de destacadas posses materiais e outras autoridades, como vereadores, clérigos e juízes. Num primeiro momento, essa informação teria um respaldo aparentemente lógico, em virtude de que, para se requerer algo formalmente à Assembleia Legislativa, ter-se-ia que lançar mão da linguagem escrita e também de alguma influência dentro do parlamento.

As fontes realmente mostram a predominância de demandas partidas de setores privilegiados do Espírito Santo. A maioria da população, desprovida de recursos pecuniários e de cultura erudita, provavelmente tentava resolver seus problemas dentro do próprio cotidiano e com meios mais diretos de que pudesse lançar mão. É possível que o paço legislativo provincial, apesar de próximo espacialmente, fosse uma realidade vista como distante pelos menos favorecidos, principalmente no início do seu funcionamento, em que era uma instituição nova para a realidade política da província. Entretanto, alguns habitantes do Espírito Santo, já nos primeiros anos do funcionamento da Assembleia Legislativa, buscavam solucionar suas demandas por meio da nova instituição e, como se verá na documentação oficial, havia esforço por parte dos parlamentares em resolver demandas diversas da província. É claro que as reformas que essa elite tentava implementar eram reformas feitas de cima para baixo, a partir de uma elite esclarecida intelectualmente, com alguns políticos de grandes posses materiais, como Francisco Pinto Homem de Azevedo, um dos mais ricos da região na primeira metade do século XIX. No entanto, descobriram-se alguns casos em que a Assembleia Legislativa ouviu pedidos de setores que tradicionalmente não recebiam atenção das elites políticas Imperiais, como se mostrará nas linhas seguintes. 


\subsection{3 - A província com a palavra}

Pedidos diversos e de diferentes pontos da província afluíam ao parlamento. Dentre eles, serão apresentados alguns. O primeiro foi localizado na sessão de treze de fevereiro de 1835. De acordo com a ata, cartas particulares de Nova Almeida anunciavam desagrados da população em consequência de uns tópicos da fala do Exmo. Presidente da Província que propunha à Assembleia Legislativa o aniquilamento dessa vila. Diante da ameaça de extinção enquanto vila pelo Presidente da Província, a população daquela comunidade apelava ao parlamento provincial, em seu primeiro mês de funcionamento, para que essa instituição resolvesse essa questão política com o representante do poder central, o Presidente Provincial. Diante disso, o deputado Manoel da Siqueira e Sá Júnior mandou um requerimento à mesa diretora da Assembleia Legislativa para que essa oficiasse à Câmara Municipal de Nova Almeida (que provavelmente articulou o pedido à Assembleia Legislativa, destoando do relato de Silva Pontes sobre a baixa atuação das Câmaras Municipais da Província) que a Assembleia Legislativa “[...] Solicita-se em promover seus interesses [...]". O requerimento de Manoel da Siqueira e Sá Júnior foi aprovado como urgência.

o primeiro secretário da mesa, João Luiz da Fraga Loureiro, afirmou que o Presidente da Província deveria tomar providências quanto a isso. Entretanto, João Clímaco de Alvarenga Rangel fez outra proposta. Em virtude de já haver uma representação da Câmara de Nova Almeida queixando-se da ilegalidade da divisão do seu termo, requereu Alvarenga Rangel que se convidasse a Comissão de Municipalidades para dar seu parecer. Luiz da Silva Alves de Azambuja Suzano, todavia, se opôs à proposta do presidente da Casa, defendendo que se deveria oficiar ao Presidente da Província, remetendo o requerimento de Sá Júnior e a representação de Nova Almeida ${ }^{138}$.

Já na ata de trinta de março de 1835, está o registro de que a

${ }^{138}$ ESTADO DO ESPÍRITO SANTO. Assembleia Legislativa. Atas. 1835-1837. 
Assembleia Legislativa do Espírito Santo recebeu um requerimento feito pelos lavradores da capital da província. O documento foi analisado pela Comissão de Agricultura e Administração dos bens provinciais, sendo que essa comissão deu como parecer a escrita de uma representação à Assembleia Geral, parecer aprovado pelo plenário ${ }^{139}$. Sendo assim, no dia 31 de março de 1835, a Assembleia Legislativa do Espírito Santo enviou uma representação à Assembleia Geral. Esse documento é revelador da demanda que os lavradores de Vitória fizeram ao parlamento do Espírito Santo. Em 1835, a província sofria as duras consequências da lei imperial de terras de quinze de novembro de 1831, que entre outros termos definia o arrendamento das terras em lotes não superiores a quarenta braças e por tempo não superior a três anos. Isso causava prejuízo à lavoura do Espírito Santo, pois os lavradores não tinham tempo de colher os resultados dos investimentos, o que os desanimava a investir em terras. Havia, ainda, a possibilidade de disputas entre antigos posseiros e arrendatários, o que levaria a uma crise social e econômica (agrícola). Diante disso, a Assembleia Legislativa do Espírito Santo, tentando romper essa dificuldade local, enviou representação para a Assembleia Geral, argumentando que ela: “[...] não somente não deve perder de vista direitos, que os antigos ocupantes haviam adquirido pela sua longa posse sobre os terrenos, como ainda devem prevenir as consequências, que o fato da desapropriação pode acarretar após si [...]"140.

Além desses dois casos, há também o exemplo do envio, pelo Presidente da Província, de um ofício do Inspetor da tesouraria, com outro da Câmara Municipal de Linhares, pedindo providências acerca do pedágio que fora estabelecido aos que passassem pelo Rio Doce $^{141}$. Também se tem o caso do clérigo Joaquim Duarte, em que

\footnotetext{
${ }^{139}$ ESTADO DO ESPÍRITO SANTO. Assembleia Legislativa. Atas. 1835-1837

140 . ARQUIVO DA ASSEMBLEIA LEGISLATIVA DO ESPÍRITO SANTO. Representação da Assembleia Legislativa do Espírito Santo à Assembleia Geral. 30/03/1835.

${ }^{141}$ ESTADO DO ESPÍRITO SANTO. Assembleia Legislativa. Atas. 1835-1837
} 
esse reverendo se queixa contra o Juiz de Órfãos da Vila da Serra ${ }^{142}$.

Essas são, pois, amostras de que os indivíduos de destaque na Província do Espírito Santo tinham, na Assembleia Legislativa Provincial, ponto de encontro da elite política local, um espaço onde suas demandas poderiam ser representadas, buscando-se nessa representação a resolução de conflitos em nível local. Dessa forma, a Assembleia Legislativa cumpria a função política institucional de ser o ponto para onde a maioria das atividades da Província confluía, gerindo e dirigindo parcialmente as outras atividades regionais ${ }^{143}$.

\subsection{4 - Uma demandante inusitada}

Em vários momentos, a elite política do Espírito Santo se dispôs a resolver questões e conflitos de seus cidadãos. Destacavam-se as demandas de homens de projeção na região, como autoridades (civis e eclesiásticas) e pessoas de alguma posse material, como os lavradores. Numa rápida observação, poder-se-ia concluir que aqueles indivíduos carentes de poder material e simbólico não teriam seus interesses representados pela elite regional, seja porque os desprivilegiados imaginassem não ter voz na nova instituição política, seja porque a própria elite política não teria interesse em sanar as demandas dos menos privilegiados.

As fontes, todavia, trouxeram uma enorme surpresa. De onde menos se poderia esperar, do setor tradicionalmente conceituado como o mais desprivilegiado da sociedade oitocentista brasileira, alguém se dispôs a clamar por socorro ao reduto da elite política regional. No ano de 1835, desenrolou-se um processo em que uma ex-escrava buscou a Assembleia Legislativa para reparar uma injustiça cometida contra sua pessoa por um Juiz de Órfãos ${ }^{144}$. Por meio

\footnotetext{
${ }^{142}$ ESTADO DO ESPÍRITO SANTO. Assembleia Legislativa. Atas. 1835-1837.

${ }^{143}$ REMOND, René. Por uma história política. Rio de Janeiro: UFRJ/FGV, 1996. p. 447.

${ }^{144}$ ARQUIVO DA ASSEMBLEIA LEGISLATIVA DO ESPÍRITO SANTO. Arrogo de Vicência Maria à Assembleia Legislativa Provincial do Espírito Santo. 1835.
} 
de seu procurador, João Nunes da Silva, a liberta Vicência Maria se queixou à Assembleia Legislativa Provincial do Espírito Santo contra o Juiz de Órfãos da Vila do Espírito Santo. A queixa provavelmente foi redigida por João Nunes, pois no final, ao invés da assinatura de Vicência, provavelmente analfabeta, aparece uma cruz acompanhada da informação - "sinal de Vicência Maria". A redação da queixa carrega na retórica para convencer os deputados da Assembleia Legislativa a promover a justiça no caso desta ex-escrava.

O drama de Vicência Maria, preta forra, começou com a morte de sua mãe, Rosa Maria, que deixou vários bens. O inventário, feito pelo Juiz de Órfãos da Vila do Espírito Santo, deixou de fora alguns escravos recebidos como bens por Vicência. O juiz de órfãos decidira colocar esses escravos em "praça", ou seja, à venda. O produto dessa venda, por sua vez, foi colocado sob a tutela de Francisco das Chagas Rofino, em nome de Vicência. Na queixa, é manifestado o desapreço de Vicência pela atitude do Juiz, que, sem sua autorização, vendera os escravos e bloqueara o produto da negociação, deixando-a “[...] sem abrigo, sem arrimo, sem meios numerários, para minha subsistência [...]". Diante dessa situação de penúria, Vicência tentara antes o socorro do Presidente da Província:

[...] Achando-me de toda sucumbida e não podendo dar alívios aos meus males, pelas injustiças que a cada passo se me faz; representei por meio de queixa ao Exmo. Presidente contra o Juiz referido; é nesse tempo que o mesmo Exmo. Presidente manda responder àquele mencionado Juiz; de cuja resposta fui mandada que usasse dos meios competentes [...]

Diante da atitude do Presidente da Província, que desconsiderou a dita queixa, Vicência teve como último recurso apelar para a elite local congregada no Paço legislativo. A revolta, matizada pela retórica, contra a atitude do mais alto funcionário do Governo Geral em terras espírito santenses, fica clara no relato seguinte, que aparece na fonte imediatamente após informar a falta de boa vontade do Presidente em resolver a referida queixa: 
[...] Ilustres Senhores não é desconhecido a V. V. S. S. que gentes de cor, principalmente em toda esta comarca, é abandonado, é pisado, é abatido, nunca tem justiça, e ainda que o tenham dasse-lhe uma coragem tal, que faz pasmar (sic) $[. . .]^{145}$.

Pela retórica, o Procurador João Nunes Pereira da Silva tentou mobilizar os deputados a favor da causa de Vicência. Um dos recursos retóricos desse arrogo à Assembleia Legislativa é a afirmação de que seus membros sabiam da situação das "gentes de cor" da Província, de serem totalmente carentes de direitos e reconhecimento pela comunidade. Não se sabe se a Assembleia Legislativa atendeu ao pedido de Vicência. A única informação concreta é que o pedido foi encaminhado à Comissão de Justiça ainda em 1835. Entretanto, esse caso dá margem para uma reflexão a respeito de como a elite política em questão encarava temas como liberdade, escravidão e raça, assuntos centrais na sociedade oitocentista brasileira.

$\mathrm{Na}$ primeira metade do oitocentos a questão da escravidão não ocupava o centro dos debates públicos do Império ${ }^{146}$. A Assembleia Legislativa do Espírito Santo tentava lidar com o problema da escravidão dentro do âmbito político. No período de 1835 a 1837, o deputado que mais interveio tratando da escravidão foi Manoel da Siqueira. Na sessão de oito de fevereiro de 1835, ele propôs que os lavradores com menos de oito escravos ou jornaleiros fossem proibidos de levantar fábricas de açúcar ${ }^{147}$. Nesse caso, o escravo é tratado apenas como mão de obra. Já na sessão de três de fevereiro de 1836, Manoel da Siqueira apresentou o projeto de lei para a captura de escravos fugidos e na sessão de nove de novembro do mesmo ano voltou ao assunto pedindo para que se requisitassem ao

\footnotetext{
${ }^{145}$ ARQUIVO DA ASSEMBLEIA LEGISLATIVA DO ESPÍRITO SANTO. Arrogo de Vicência Maria à Assembleia Provincial do Espírito Santo. 1835.

${ }^{146}$ CARVALHO, José Murilo de. Pontos e bordados: escritos de história política. Belo Horizonte: Editora da UFMG, 1998. p. 51.

${ }^{147}$ ESTADO DO ESPÍRITO SANTO. Assembleia Legislativa (1835-1837). Ata de Sessão Legislativa. Vitória. 1835.
} 
Presidente da Província providências quanto à captura de escravos fugidos. O deputado Ayres Tovar, por sua vez, também tocou no tema dos escravos fugidos, pedindo que o Presidente da Província tomasse providência quanto a isso ${ }^{148}$.

Nessas falas, o tema da escravidão foi tomado em seus aspectos cotidianos: repressão às fugas e trabalho. Além disso, tais intervenções reafirmam a importância conferida à escravidão como instituição social. Outro deputado, entretanto, tinha uma visão mais global e matizada do tema. Em 1835, o padre João Luiz da Fraga Loureiro pediu providências ao Presidente da Província sobre o desembarque de africanos na costa do Espírito Santo. Na primeira metade do século XIX, o Brasil atravessava um contexto em que as pressões internacionais contra o tráfico de escravos eram enormes. Logo na chegada da família real ao Brasil, Londres extraiu de D. João VI a promessa de colaborar com os ingleses para a promoção da gradual abolição do tráfico negreiro, proibindo-se que tal comércio fosse realizado fora dos domínios portugueses na África. Três anos depois, foi assinado um alvará que limitava por tonelada a quantidade de escravos que o navio negreiro poderia carregar, além de ordenar medidas relativas à higiene e alimentação dos cativos em trânsito. Esse documento, entretanto, teve pífio resultado. Já no congresso de Viena, em 1815, Portugal assinou um tratado abolindo o tráfico ao norte do Equador, em troca do perdão de 300 mil Libras restantes de empréstimo efetuado por Londres a Lisboa em 1809.

A questão do tráfico, contudo, se arrastou até a Independência. Os ingleses colocaram como condição para o reconhecimento da autonomia política do Brasil a abolição do comércio negreiro transatlântico. Um ano após a Independência, José Bonifácio informou ao representante britânico no Brasil que a nova monarquia americana observaria o tratado de 1815. Simultaneamente, os debates na Assembleia Constituinte brasileira caminhavam para a abolição do

${ }^{148}$ ESTADO DO ESPÍRITO SANTO. Assembleia Legislativa (1835-1837). Ata de Sessão Legislativa. Vitória. 1835. 
tráfico em quatro anos. Já no ano de 1826, D. Pedro I assinou uma Convenção que tinha como primeiro artigo o estabelecimento do prazo de três anos para o fim do tráfico nacional de escravos, tempo que seria contado a partir da ratificação do tratado pelo governo inglês, sendo que após esse período o tráfico de almas seria considerado pirataria. Nos demais artigos, o Brasil concordava em manter os tratados anteriores (anglo-portugueses) e instituíam-se duas comissões mistas, uma no Rio de Janeiro e outra em Serra Leoa, na África, com a finalidade de resolver questões relativas a apresamentos, garantindo a liberdade dos africanos encontrados nesta situação. A Convenção foi ratificada a 13 de março de 1827, transformando automaticamente o tráfico nacional em pirataria a partir de treze de março de 1830.

Oficialmente, portanto, o tráfico de escravos se extinguiu em 1830. Entretanto, na prática, o processo era outro. Depois do ano do término oficial do tráfico negreiro, as entradas de escravos continuavam volumosas no Brasil. Entre 1831 e 1834, os desembarques dos negreiros foram de quarenta mil africanos por ano. Essa monta oscilou entre quatorze mil a 23 mil anuais, durante a primeira metade da década de 1840. Já entre 1846 e 1850, essa cifra alcançou o valor de cinquenta mil por ano. Percebe-se claramente que o tráfico não se encerrou pela determinação legal de $1830^{149}$.

Uma vez no Brasil, essa massa escrava era distribuída no mercado consumidor nacional, no qual se incluía o Espírito Santo. A preocupação de João Luiz da Fraga Loureiro com o desembarque de africanos demonstra que o Espírito Santo também estava entre os consumidores que burlavam a determinação do fim do tráfico. Enquanto outros deputados reafirmavam a estrutura escravista, João Luiz da Fraga Loureiro defendia o cumprimento da lei nacional que coibia a entrada de africanos no país. A figura de Fraga Loureiro se destaca porque ele registrou sua opinião também fora do âmbito parlamentar. Loureiro era poeta e intelectual e, em 1825, com apenas

${ }^{149}$ FLORETINO, Manolo. Em costas negras. São Paulo: Companhia das Letras, 1997. p. 42-43. 
20 anos, compôs os seguintes versos:

O homem nasce livre, alma natura

O dota com a grata independência,

E só ele por comum conveniência

Alcina trama contra essa ventura

É lei, somente a lei à qual feitura

$O$ voto nacional tem ascendência;

O mais é despotismo, é prepotência,

Que o bruto tolera, o escravatura.

Do acaso é a obra a cor, a jerarchia.

É uma só prole dos humanos,

Se abate-o o crime, virtude a aprecia;

Crime é ser indiferente aos gerais danos;

É virtude a razão tendo por guia,

Aos homens fazer bem, punir os tiranos ${ }^{150}$

De acordo com o poema, Loureiro entende que a liberdade é um direito natural, do qual apenas o indivíduo pode abrir mão, sendo que outra causa para este se ausentar da liberdade só tem um nome: tirania. Além disso, a cor seria apenas uma ocorrência do acaso, não devendo ela ser fonte de uma hierarquização entre os seres humanos.

Esse poema de Loureiro, entretanto, não constitui apenas a divagação de um jovem sonhador. Posteriormente, já ordenado padre, o poeta mostrava em seu cotidiano religioso e artístico sua aproximação das populações de cor do Espírito Santo. Loureiro era sempre o pregador escolhido para falar e declamar versos em louvor a São Benedito, o santo negro venerado no Espírito Santo pelas devoções de São Francisco e da Igreja do Rosário. Um dos versos compostos por Loureiro em honra a São Benedito foi preservado:

Dizer-se no convento

o culto de Benedito

\footnotetext{
${ }^{150}$ CLAÚDIO, Afonso. História da literatura Espírito Santense. Rio de Janeiro: Biblioteca reprográfica xerox, 1981. p. 118.
} 
Não se torna mais bonito

Com muito mais luzimento,

É negar um pensamento

Ministrado pela história,

É ofuscar uma glória,

Que sempre lhe pertenceu,

É dizer que não venceu

$\mathrm{Na}$ cidade de Vitória.

Viva o grande Benedito,

Estrela do firmamento,

Que no claustro e no convento,

Mais figura, é mais bonito.

Viva sempre e seja invicto

Nosso empenho sublimado,

Viva todo apaixonado

Que com gosto e fervor tanto,

Dá louvor ao nosso santo

No convento colorado

Em uma manhã calmosa

Deste mês grato, gentil,

Fui colher de flores mil

Uma cesta preciosa;

Colhi o cravo e a Rosa,

Alecrim, perfeito amor;

Com elas fui eu compor

Um belo ramo esquisito

Para dar ao Benedito

Como oferta de primor

Entre as flores cobiçadas

Colhi cheirosa madressilva,

A bonina, a sempre viva, pela aurora rociadas

Para o herói coroar,

E para não lhe faltar

Com meu rústico presente,

Aqui venho fielmente

Em seus braços entregar ${ }^{151}$

É interessante observar um membro das elites, filho do Sargen-

${ }^{151}$ CLÁUdIO, 1981, p. 121. 
to-Mor Loureiro, por meio de suas composições, defender negros, escravizados ou livres, evidenciando que eram pessoas dotadas de direitos e prejudicadas pela tirania da escravidão. A manifestação de João Luiz da Fraga Loureiro contra o tráfico em nível provincial e seu vínculo religioso com os grupos negros locais compõem um dos diversos matizes que a situação negra assumiu no Brasil escravista. Não se conhece nenhum escrito de Loureiro ou de outro membro da primeira legislatura da Assembleia Legislativa do Espírito Santo que defenda transformações estruturais na escravidão, o que também não aconteceu no contexto nacional da primeira metade do oitocentos.

O escrito mais importante nesse sentido estava na representação de José Bonifácio à Assembleia Constituinte de 1823. No documento, Bonifácio apresentava suas propostas com respeito à escravidão. De início, o autor da representação defendia a necessidade de se abolir o tráfico de almas, a melhora da situação dos atuais cativos e a promoção da emancipação deles. Bonifácio via a dificuldade da existência de uma constituição liberal e duradoura em um país habitado pela "multidão imensa de escravos brutais e inimigos". Mais adiante, ele argumentava que a causa da brutalidade animal dos escravos estava nos brancos, que tiranizavam e reduziam os africanos e descendentes à condição animalesca. Depois de culpar os senhores pela condição dos negros, Bonifácio também defendia a tese sobre a verdadeira essência do negro. Para Bonifácio, o negro era um homem como outro qualquer, com direito à liberdade e aos outros direitos naturais dados pela providência a todos os homens. Por fim, Bonifácio não defendia uma abolição abrupta da escravidão, o que prejudicaria a sociedade (de acordo com o pensador), mas, pelo contrário, uma emancipação gradual ${ }^{152}$. Numa visão política, Bonifácio condenava incisivamente a escravidão, vendo nela uma instituição que corrompia os senhores, os escravos e a sociedade

${ }^{152}$ DOLHNIKOLF, Miriam (Org.). José Bonifácio de Andrada e Silva. São Paulo: Companhia das Letras, 2000. p. 23-32. 
como um todo. Mas, como estrategista afinado com a situação de seu país, ele tinha o olhar pragmático de que o desaparecimento instantâneo da mão de obra compulsória poderia quebrar o país, por isso a necessidade de uma transição que preparasse a economia.

A respeito da posição da elite brasileira dirigente frente à escravidão, Adriana Campos assim se manifesta:

\begin{abstract}
[...] Em razão da complexa situação da camada dirigente brasileira, que nem sempre era oriunda dos setores dominantes da economia, a ação política realizava-se com alguma autonomia, mas o limite estava na unidade em torno de algumas bases, como a manutenção da escravidão. Vários homens públicos deixaram de lado sua formação baseada nos ideais da Ilustração e transigiram com instituições em absoluto conflito com os princípios do Iluminismo, como a escravidão [...]. O "liberalismo brasileiro" [...] pode ser compreendido como um corpo de pensamentos e condutas que não dependia tanto dos modelos estrangeiros, mas constituía-se numa reação prática e teórica ante as condições sociais, econômicas e políticas recebidas do período colonial, durante a primeira fase de construção de um governo nacional ${ }^{153}$.
\end{abstract}

Além dos poemas, não se conhecem escritos de João Luiz da Fraga Loureiro ou de algum outro membro da elite política que tenham sistematizado uma argumentação com respeito à situação do negro. A proximidade religiosa de Loureiro com os grupos negros apontou para uma defesa poética do negro enquanto ser humano, mas dentro do parlamento local a escravidão não foi objeto de contestação na primeira metade do século dezenove. Entretanto, o fato de uma preta forra ter sua reclamação acolhida portas a dentro do paço provincial, e encaminhada para uma comissão, demonstra que o parlamento local não era uma instituição tão distante dos diversos seguimentos sociais, incluindo aqueles que migravam do universo da escravidão para o mundo dos livres. Apesar da hierar-

\footnotetext{
${ }^{153}$ CAMPOS, Adriana Pereira. Nas barras dos tribunais: direito e escravidão no Espírito Santo do Século XIX. 276 f. Tese (Doutorado em História) - Programa de Pós-Graduação em História Social, Universidade Federal do Rio de Janeiro, Rio de Janeiro, 2003. p. 61.
} 
quização daquela sociedade, a elite política tinha que manter um diálogo com os demais grupos, mesmo que esse diálogo variasse em sua forma de acordo com o seguimento tratado.

\section{2 - OS DEPUTADOS RESPONDEM}

A principal forma de a elite se manifestar, no momento estudado, era pelo uso de instrumentos institucionais que dessem uma solução às demandas levadas ao parlamento provincial do Espírito Santo. Após compartilharem experiências e valores em outros locais de poder, os deputados se encontraram dentro de uma nova corporação política no cenário nacional, com papel fundamental para o andamento dos negócios públicos da província do Espírito Santo. Dentro dessa nova realidade, esses deputados tiveram que negociar para responderem dentro da legalidade às demandas locais, na forma de leis ou representações enviadas ao poder central para que este pudesse resolver as questões a que o poder legislativo regional não podia dar solução. Como visto anteriormente, a legislatura de 1835 a 1837 preocupou-se, no momento de confeccionar suas leis, com o arranjo administrativo da província dentro da nova realidade nacional de fortalecimento do poder político provincial, por isso a esmagadora quantidade de leis voltadas para dar uma nova ordem à administração regional.

Entretanto, nem todas as demandas locais poderiam ser resolvidas pelo parlamento provincial. $\mathrm{O}$ ato adicional não instalou um federalismo pleno, mas sim uma descentralização parcial. Nesse sentido, muitas das demandas surgidas na sociedade espírito-santense eram levadas ao parlamento provincial, onde eram debatidas e, quando em virtude de limitações materiais ou legais, não podiam ser satisfeitas em nível local, eram enviadas para algum órgão do poder central, como a Assembleia Geral, o presidente de província, algum ministério e até para a própria majestade imperial. Essas demandas subiam ao centro por meio dos ofícios ou das 
representações. Os ofícios eram geralmente enviados ao Presidente da Província, representante do poder central mais próximo da Assembleia Legislativa, exigindo atitudes, informações ou esclarecimentos. As representações, por sua vez, eram documentos enviados a instâncias superiores da administração imperial. No período de 1835-1838, representações com temas variados foram enviadas ao Governo Geral do Império pelo parlamento provincial do Espírito Santo. Esses documentos são muito interessantes por serem, em grande medida, discursos políticos que refletiam a opinião da Assembleia Legislativa como corporação política. Evidencia isso o fato de que, antes de serem mandadas para o governo geral, as representações eram aprovadas pelo parlamento local.

É fundamental para este trabalho o detalhe de que os projetos de lei, os ofícios e as representações eram a consubstanciação em discurso político de uma demanda levantada no parlamento por um deputado que geralmente estava falando em nome de algum grupo. Daí o parlamento analisava a demanda e, caso não pudesse solucioná-la, nomeava uma comissão que redigiria a representação.

O interessante para este trabalho é localizar, por meio das atas da Assembleia Legislativa, as falas dos deputados que propuseram a elaboração desses documentos dentro do paço, para que se possa, analisando essas proposições, se ter alguma indicação do comportamento político desses legisladores, buscando-se a ligação desses comportamentos políticos com as trajetórias institucionais e profissionais desses homens. Para tanto, na tabela abaixo, foram reunidas de maneira esquemática todas as propostas dos deputados, seja de ofícios, projetos de lei ou representações ao governo central, com a indicação das sessões em que essas falas ocorreram: 
TABELA 8 - FALAS DOS DEPUTADOS DA PRIMEIRA LEGISLATURA DA ASSEMBLEIA

PROVINCIAL DO ESPÍRITO SANTO ${ }^{154}$

\begin{tabular}{|c|c|c|}
\hline DEPUTADO & DEMANDA & SESSÃO \\
\hline Dionísio A. Resendo & $\begin{array}{l}\text { Pedir ao governo documentos do extinto Conselho } \\
\text { Geral }\end{array}$ & $03 / 02 / 1835$ \\
\hline Dionísio A. Resendo & $\begin{array}{l}\text { Projeto de resolução autorizando a Câmara } \\
\text { Municipal de Vitória a demolir parte do antigo Forte } \\
\text { do Carmo para abertura de uma rua }\end{array}$ & $19 / 02 / 1835$ \\
\hline Dionísio A. Resendo & Inutilidade da Alfândega & $28 / 02 / 1835$ \\
\hline Dionísio A. Resendo & Arrendamento de terras & $30 / 03 / 1835$ \\
\hline Dionísio A. Resendo & Felicitação ao Regente & $21 / 01 / 1836$ \\
\hline Dionísio A. Resendo & Governo esclarecer quantias destinadas às Câmaras & $04 / 02 / 1836$ \\
\hline Dionísio A. Resendo & $\begin{array}{l}\text { Informação da quantia destinada às obras públicas } \\
\text { em anos anteriores }\end{array}$ & $04 / 02 / 1836$ \\
\hline Dionísio A. Resendo & Indenização de obras públicas & $11 / 02 / 1836$ \\
\hline Dionísio A. Resendo & $\begin{array}{l}\text { Regulação dos vencimentos de ordenados dos } \\
\text { empregados provinciais quando impedidos ou } \\
\text { quando deixarem seusempregos }\end{array}$ & $17 / 11 / 1836$ \\
\hline Dionísio A. Resendo & $\begin{array}{l}\text { Perguntar ao presidente a quantia despendida } \\
\text { na obra da Casa da administração das rendas } \\
\text { provinciais }\end{array}$ & $19 / 11 / 1836$ \\
\hline Dionísio A. Resendo & $\begin{array}{l}\text { Perguntar ao presidente se os párocos da província } \\
\text { teriam a mesma licença que os demais empregados } \\
\text { provinciais }\end{array}$ & $24 / 11 / 1836$ \\
\hline Dionísio A. Resendo & $\begin{array}{l}\text { Oficiar ao presidente para que exija do juiz de paz } \\
\text { de Itapemirim informações à Assembleia sobre o } \\
\text { processo concernente a um assassinato }\end{array}$ & $26 / 11 / 1836$ \\
\hline Dionísio A. Resendo & $\begin{array}{l}\text { Pedir à Câmara Legislativa Geral para o Espírito } \\
\text { Santo ter mais um deputado }\end{array}$ & $28 / 11 / 1836$ \\
\hline Manoel da Siqueira & Arrematação das vendas provinciais em Ata Pública & $23 / 02 / 1835$ \\
\hline Manoel da Siqueira & $\begin{array}{l}\text { Juntar a aula de francês e retórica à aula de Gramática } \\
\text { da Capital }\end{array}$ & $23 / 02 / 1835$ \\
\hline Manoel da Siqueira & $\begin{array}{l}\text { Governo informar a quantia do rendimento das } \\
\text { últimas rematações dos contratos da província pela } \\
\text { extinta junta da Fazenda }\end{array}$ & $06 / 02 / 1835$ \\
\hline Manoel da Siqueira & $\begin{array}{l}\text { Pedir informação ao presidente da província sobre o } \\
\text { potencial dos rios do Espírito Santo }\end{array}$ & $07 / 02 / 1835$ \\
\hline Manoel da Siqueira & $\begin{array}{l}\text { Pedido de Comissão para revisão do Relatório do } \\
\text { presidente da província }\end{array}$ & $08 / 02 / 1835$ \\
\hline Manoel da Siqueira & Criação de uma Companhia de Ligeiros & $08 / 02 / 1835$ \\
\hline
\end{tabular}

\footnotetext{
${ }^{154}$ A tabela não contempla as sessões de 1837 em virtude dessas atas não terem sido encontradas.
} 
=Figurões da terra : trajetórias e projetos políticos no Espírito Santo do Oitocentos - 115

Manoel da Siqueira

Manoel da Siqueira

Manoel da Siqueira

Manoel da Siqueira

Manoel da Siqueira

Manoel da Siqueira

Manoel da Siqueira

Manoel da Siqueira

Manoel da Siqueira

Manoel da Siqueira

Manoel da Siqueira

Manoel da Siqueira

Manoel da Siqueira

Fraga Loureiro

Fraga Loureiro

Fraga Loureiro

Fraga Loureiro

Fraga Loureiro

Fraga Loureiro

Fraga Loureiro

Fraga Loureiro

Fraga Loureiro

Fraga Loureiro

Azambuja Suzano

Azambuja Suzano
Proibição de que lavradores que não tenham mais de oito escravos ou jornaleiros levantem fábricas de açúcar

Criação de Guardas de Polícia

Apoiar a Câmara Municipal de Nova Almeida diante da fala do presidente da província que propunha o aniquilamento dessa câmara

Projeto para apanhar escravos fugidos

Oficiar ao vice-presidente da província para esse tomar acento na Assembleia Provincial

Aumento das côngruas dos vigários das freguesias da província

Projeto autorizando o governo a convidar formados em direito para se estabelecerem na cidade com banca de advocacia, ordenado e ajuda de custo

Gastos do governo provincial com a Casa da Tesouraria das Rendas Provinciais

Restrição do número de juízes de paz

Providências do Presidente quanto à captura de escravos fugidos

Divisão de pedestres

Pagamento do dízimo da cultura agrária

Pedir ao presidente da província informação das quantias dadas às Câmaras e cópia do tombamento de seus patrimônios, bem como o valor do rendimento anual

Providência sobre a escola de primeiras letras

Extinção dos títulos de sesmarias, não cultivadas no prazo de dez anos, nas margens do Rio Doce

Criação de Guardas de Polícia

Privilégio de 10 anos para o empreendedor que estabelecesse tipografia na província para imprimir os papéis da administração pública

Extinção das sesmarias às margens do Rio Doce

Providências do presidente da província contra o desembarque de africanos no Espírito Santo

Instrução das guardas nacionais

Criação de uma tesouraria provincial

Perguntar ao Governo Provincial sobre a estrada de Minas

Governo ordenar ao empresário a limpa da estrada de Minas

Pedir ao Governo esclarecimentos sobre a obra do palácio

Autoriza presidente da província a fazer nova e melhor divisão dos terrenos e Comarcas
$08 / 02 / 1835$

$12 / 02 / 1835$

$13 / 02 / 1835$

$03 / 02 / 1836$

$31 / 10 / 1836$

$31 / 10 / 1836$

$02 / 11 / 1836$

$03 / 11 / 1836$

$08 / 11 / 1836$

$09 / 11 / 1836$

$09 / 11 / 1836$

$09 / 11 / 1836$

$23 / 11 / 1836$

$08 / 02 / 1835$

$11 / 02 / 1835$

$12 / 02 / 1835$

$14 / 02 / 1835$

$16 / 02 / 1835$

$28 / 02 / 1835$

$28 / 02 / 1835$

$28 / 01 / 1836$

$04 / 02 / 1836$

$10 / 02 / 1836$

$10 / 02 / 1835$

$10 / 02 / 1835$ 
Azambuja Suzano

Azambuja Suzano

Azambuja Suzano

Azambuja Suzano

Azambuja Suzano

João Clímaco

João Clímaco

João Clímaco

João Clímaco

João Clímaco

João Clímaco

João Clímaco

Duarte Carneiro

Duarte Carneiro

Duarte Carneiro

Duarte Carneiro

Ayres Tovar

Ayres Tovar

Ayres Tovar

José Pimentel

Manoel Pinto Rangel e Silva

Joaquim da Silva Caldas
Autoriza presidente da província a construir igreja no centro do povoado de Maricará

Permissão para o presidente da província construir igreja com recursos da Fazenda Pública

Projeto de resolução suprimindo a aula que rege o professor de primeiras letras Ignácio Santos Pinto, incorporando-a ao ensino mútuo

Perguntar ao presidente da província os obstáculos à concessão de sesmarias no Rio Doce e em toda província

Pedir ao presidente da província estatística nominal dos fogos em cada distrito de todas as freguesias da Província

Propõe criação de aula de meninas

Estabelece número e vencimento dos empregados da secretaria do governo

Estabelece ordenado dos Juízes de Direito da Província

Exigir esclarecimento do governo sobre o estado da estrada de Minas

Pedir ao governo informações das participações oficiais pela morte do preso Joaquim Róis Fess

Requer que a Assembleia tenha duas comissões permanentes

Oficiar ao presidente da província para que mande patrulhar a cidade pelas guardas nacionais durante a noite

Projeto de Lei sobre impostos

Indica que o projeto sobre sesmarias não cultivadas seja levado à Assembleia Geral

Providências para recolhimento dos enfermos morféticos

Requer que os projetos tendentes a povoar a estrada de Minas e dar de propriedade os terrenos aforados por vinte anos fossem levados à Assembleia Geral

Formação de uma guarda de polícia

Presidente da província dar providências quanto aos escravos fugidos

Presidente da Província informar sobre as quantias que os vigários receberam para o reparo das matrizes

Pedir ao presidente da província os mapas estatísticos ou a divisão antiga dos distritos

Requer saber da tesouraria provincial por quanto foi arrematado o décimo do açúcar exportado

Criação de aula de gramática latina na Vila de São Mateus
$16 / 02 / 1835$

$16 / 02 / 1835$

$26 / 02 / 1835$

$27 / 02 / 1835$

$22 / 11 / 1836$

$11 / 02 / 1835$

$11 / 02 / 1835$

$11 / 02 / 1835$

$16 / 02 / 1835$

$16 / 02 / 1835$

$31 / 10 / 1836$

$10 / 11 / 1836$

$08 / 02 / 1835$

$27 / 02 / 1835$

$28 / 02 / 1835$

$29 / 03 / 1835$

17/02/1835

$06 / 02 / 1836$

$23 / 11 / 1836$

$21 / 11 / 1836$

$15 / 01 / 1836$

$12 / 02 / 1835$ 
Por meio dessa tabela, é possível a apreensão de algumas informações relevantes. Dentre as falas no parlamento provincial do Espírito Santo, percebe-se a predominância de dois deputados: Manoel da Siqueira e Sá Júnior (dezenove falas) e Dionísio Álvaro Rozendo (treze falas), dois militares de carreira. Por esse ponto, já se nota que os militares não eram apenas numericamente predominantes, mas também se destacavam por um considerável relevo nas intervenções nos debates legislativos. O terceiro deputado que mais intervinha era João Luis da Fraga Loureiro, um padre, tendo sido computadas onze intervenções. Dividindo o quarto lugar, com sete intervenções cada, estão Azambuja Suzano, membro da burocracia civil provincial, e João Clímaco de Alvarenga Rangel, um padre. Baseando-se nessa hierarquia quantitativa das falas entre esses deputados, dividiu-se essa sessão em três partes para o estudo de como essas falas poderiam ser ligadas à carreira política desses oradores legislativos.

\subsection{1 - Os militares com a palavra}

Manoel da Siqueira e Sá Júnior, em primeiro lugar, possuía carreira de destaque antes de 1835. Ocupando cargos militares, destacou-se como Capitão-Mor da cidade de Vitória, sendo ativo no serviço de recrutamento para o Batalhão 12 da $1^{\mathfrak{a}}$ linha do Exército. Além de militar, Manoel da Siqueira e Sá Júnior era negociante bem estabelecido, sendo que em 1819 tinha uma sumaca. Para completar sua trajetória antes de 1835, Sá Júnior também participou da vida política local, como membro da Câmara Municipal de Vitória no período de $1830-1831^{155}$, tendo também sido eleito para o Conselho Geral de Província em $1829^{156}$.

Nos discursos de Sá Júnior percebe-se uma predominância de

\footnotetext{
155 BIBLIOTECA NACIONAL. Documento C-0114, 40. Documentos referentes a Manoel da Siqueira de Sá. 1830-1855.

${ }^{156}$ ARQUIVO DA ASSEMBLEIA LEGISLATIVA DO ESPÍRITO SANTO. Ata de apuração dos votos para conselho geral de província do ES. 1829.
} 
temas da alçada administrativa. Das dezenove falas, oito são referentes a essa temática. Destaca-se dentro dessas falas a preocupação com questões financeiras. Se, por um lado, o deputado preocupava-se com a entrada de recursos nos cofres provinciais, por exemplo, pedindo informações sobre as antigas arrecadações da extinta Junta da Fazenda e sobre os rendimentos do imposto do dízimo sobre a cultura agrária, por outro, o mesmo deputado se interessava pela maneira como os recursos provinciais estavam sendo gastos. Nesse sentido, requereu que a Assembleia Legislativa pedisse ao governo provincial o orçamento que foi feito para edificação da casa para a tesouraria das Rendas Provinciais e informações sobre quanto já havia sido gasto com essas obras, o que ainda faltava para sua conclusão e o que ainda seria despendido ${ }^{157}$. Sem tomar uma atitude monolítica em relação aos gastos, Sá Júnior propôs o aumento das côngruas (remuneração) dos vigários da província.

O segundo tema predominante no discurso de Sá Júnior refere-se à questão da segurança no Espírito Santo. Propôs a formação de uma Companhia de Ligeiros e de Guardas de Polícia e requereu informações sobre a divisão da tropa de pedestres da Província. Também demonstrou uma intensa preocupação com os escravos fugidos. Na sessão de três de fevereiro de 1836, propôs um projeto de lei que cuidasse do apanho de cativos fugidos. Já na sessão de nove de novembro do mesmo ano requereu que se perguntasse ao Presidente da Província sobre as atitudes tomadas em relação aos escravos fugidos.

No caso de Dionísio Álvaro Rozendo, destacam-se em suas intervenções, da mesma forma, a preocupação esmagadora com questões administrativas. Dentro dessas falas também predominam as intervenções que envolvem questões financeiras. Saber quanto o governo destinava para as câmaras e para as obras públicas, pedido de indenização do Governo Geral e regulação dos rendimentos dos empregados provinciais são alguns exemplos das falas de Dionísio

${ }^{157}$ ESTADO DO ESPÍRITO SANTO. Assembleia Legislativa. Ata (1835-1837). 
Álvaro Resendo em que esse deputado se preocupava com as questões financeiras do Espírito Santo.

Como seus pares, Dionísio Álvaro Resendo também não era novato na vida pública do Espírito Santo. Como militar, em 1833 foi nomeado oficial maior. No ano seguinte, foi investido do cargo de Escrivão da Comissão da Irmandade da Misericórdia, que tomaria as contas do ex-tesoureiro Capitão João Pinto Ribeiro de Seixas ${ }^{158}$. Como político, foi secretário da Câmara Municipal de Vitória em $1830^{159}$. Já no ano de 1835 assumiu a presidência da Província. Sendo militar e político de carreira, Álvaro Resendo demonstrou sua preocupação predominante com questões administrativas da Província do Espírito Santo.

É interessante notar que esses dois deputados, de carreiras semelhantes nas áreas militar e política, tenham destacado em suas falas pedidos de providências para questões administrativas do Espírito Santo. Como visto anteriormente, em sua primeira legislatura, a Assembleia Legislativa do Espírito Santo teve como ponto forte a maioria de suas leis aprovadas com ênfase na administração provincial. Nesse ponto, percebe-se que os deputados que mais intervieram em plenário tiveram suas preocupações voltadas para a reorganização administrativa da província no período pós-ato adicional.

\subsection{2 - Os padres com a palavra}

Apesar da predominância de temas administrativos nas falas dos deputados na primeira legislatura, o terceiro deputado que mais interveio nas sessões legislativas foge a esse parâmetro. De acordo com o quadro, percebe-se que nas falas de João Luiz da Fraga Loureiro

\footnotetext{
${ }^{158}$ SCHWAB, Affonso. A irmandade e a Santa Casa da Misericórdia do Espírito Santo. Vitória: Arquivo Público Estadual, 1979. p. 59.

${ }^{159}$ BIBLIOTECA NACIONAL. Documento C-0032, 009. nº. 1. Requerimento encaminhado ao Ministério do Império solicitando aposentadoria. 1830-1840.
} 
há um equilíbrio das questões da esfera estritamente política e administrativa com os temas de outras alçadas. Nota-se um equilíbrio do número de falas entre os temas administrativos, de segurança e econômicos. Em relação à administração, Loureiro demonstrou sua preocupação com a criação de uma tesouraria provincial e com a criação de uma tipografia para impressão dos papéis destinados à administração provincial. Em sua preocupação econômica, também se debruçou sobre a situação da comunicação terrestre no Espírito Santo. Na sessão de quatro de fevereiro de 1836, sugeriu que se perguntasse ao governo provincial o estado da estrada de Minas $^{160}$. Já na sessão de dez de fevereiro de 1836, o deputado voltou a sugerir que se falasse ao governo provincial a fim de que ordenasse ao empresário responsável a limpa da referida estrada que ligava o Espírito Santo a Minas Gerais ${ }^{161}$. Além do tema das estradas, João Luiz da Fraga Loureiro também se preocupou com a questão fundiária. Na sessão de onze de fevereiro de 1835 propôs projeto de resolução para extinção dos títulos de sesmaria nas margens do Rio Doce - sesmarias daqueles que no prazo de dez anos não as tivessem cultivado, questão que o deputado levantou novamente na sessão de dezesseis de fevereiro de 1835.

Em relação à segurança da Província, na sessão legislativa de 28 de fevereiro de 1835 Loureiro pediu para se oficiar ao presidente a fim de que tomasse providências contra o desembarque de africanos na costa do Espírito Santo ${ }^{162}$. Além disso, na sessão de doze de fevereiro de 1835 o deputado propôs a criação de guardas de polícia na Província.

Por contraste nota-se que, enquanto Dionísio Álvaro Resendo e Manoel da Siqueira e Sá se dedicavam a questões voltadas para a estruturação da ordem administrativa, legal e política do Espírito Santo, Loureiro preocupava-se, além disso, e com a mesma intensidade, com questões mais ligadas à vida cotidiana da Província.

\footnotetext{
${ }^{160}$ ESTADO DO ESPÍRITO SANTO. Assembleia Legislativa. Atas. 1835-1837.

${ }^{161}$ ESTADO DO ESPÍRITO SANTO. Assembleia Legislativa. Atas. 1835-1837.

${ }^{162}$ ESTADO DO ESPÍRITO SANTO. Assembleia Legislativa. Atas. 1835-1837.
} 
Resolver os problemas de comunicação, de educação e de mão de obra local também estava na pauta de Loureiro.

Enquanto Dionísio e Siqueira e Sá tiveram uma carreira militar antes de chegar ao Paço legislativo, Fraga Loureiro teve uma trajetória que percorreu vias distintas. Como visto anteriormente, Loureiro teve uma carreira antes de 1835 marcada pela atuação como poeta e padre, sendo conhecido por sua atuação nas festas em louvor a São Benedito e por circular por diferentes paróquias. Entende-se que essa circulação, os estudos superiores e o contato com setores populares contribuíram para que, uma vez no parlamento, Loureiro tivesse suas falas voltadas para questões mais pragmáticas e cotidianas do Espírito Santo.

Loureiro, por outro lado, não foi encontrado ocupando outro cargo político antes de 1835, ao contrário de Dionísio Álvaro Resendo, que já havia ocupado os cargos de vereador e presidente de província. Portanto, enquanto Dionísio Álvaro Resendo possuía uma atitude política de cunho estadista no parlamento, buscando organizar a ordem política do Espírito Santo dentro da realidade pós-Ato Adicional, Loureiro voltava-se para as questões econômicas e sociais da província.

Como dito em linhas acima, João Clímaco de Alvarenga Rangel estava entre os deputados que mais apresentavam propostas dentro do parlamento. Filho de fazendeiro, nascido em 1799, na Vila de São José do Queimado, na época pertencente à Vitória, Alvarenga Rangel seguiu as carreiras de padre, intelectual e político. Em 1819 recebeu a tonsura das ordens menores, sendo que três anos depois foi investido das funções de subdiácono e presbítero, tornando-se padre em seguida. Como intelectual, em 1833 recebeu o título de Bacharel em Ciências Sociais e Jurídicas pela Academia de Ciências Sociais e Jurídicas de São Paulo. Mas, antes disso, em 1827 conquistou, por provisão imperial, o direito de exercer qualquer cadeira de filosofia racional e moral ${ }^{163}$. Como político, destacou-se como deputado da

${ }^{163}$ PEREIRA, Amâncio. Traços biográficos. Vitória: Papelaria e Tipografia de A. Moreira Dantas, 
Assembleia Geral no período de 1834 a 1837.

Dentre as falas de Alvarenga Rangel não se nota um destaque para uma questão em específico. Apesar das preocupações administrativas em estabelecer o número e o vencimento dos empregados da secretaria do governo e do ordenado dos juízes de direito do Espírito Santo, também se preocupava com questões como a criação de uma aula para meninas, com a estrada de Minas e com a segurança por meio do patrulhamento da cidade por guardas à noite.

\subsection{3 - Os burocratas com a palavra}

Por fim, o último deputado que mais se destacou nas falas do plenário foi Luiz da Silva Alves de Azambuja Suzano. Azambuja Suzano era componente da burocracia civil. Encontrou-se que de 1811 a 1825 ele foi Escriturário da Junta da Fazenda. Além disso, em 1822 era Juiz de Paz e de Órfãos ${ }^{164}$. Nas falas desse deputado encontrou-se a predominância de questões envolvendo a administração pública, principalmente no quesito obras públicas. É importante destacar aqui a repetição do interesse pela questão fundiária, sendo que o deputado mandou perguntar ao Presidente da Província o que impediria a concessão de sesmarias na localidade.

Percebe-se, por esses casos, que os deputados estavam, de maneira distinta, movidos por suas diferentes formações profissionais, buscando estruturar a Província do Espírito Santo dentro de um novo contexto legal. Enquanto alguns tentavam organizar o aparato administrativo dentro dessa nova legalidade, caso de Dionísio Álvaro Resendo e Manoel da Siqueira e Sá, outros, como João Luiz da Fraga Loureiro, tentavam atender a demandas mais estruturais que há muito desafiavam a Província, mas que agora deveriam

\footnotetext{
1897. p. 17-26.

${ }^{164}$ DAEMON, Basílio Carvalho. Província do Espírito Santo: sua descoberta, história cronológica, sinopse e estatística. Vitória: O Espírito-santense, 1879. Disponível em: <www.estacaocapixaba.com.br>. Acesso em: 18 abr. 2007.
} 
ser resolvidas dentro de novas regras, quais sejam a existência de um parlamento regional com relativo poder de legislar e com uma capacidade de se comunicar com o Governo Geral nunca vista.

De acordo com essa rápida observação, percebe-se que à proporção que os militares e a burocracia civil da Assembleia Legislativa, em sua primeira legislatura, se debruçavam sobre temas de uma alçada mais administrativa, o setor clerical, representado por João Luiz da Fraga Loureiro, se preocupava com temas mais gerais relativos ao Espírito Santo. Daí surge a questão: a carreira na hierarquia clerical teria propiciado aos deputados que a seguiram uma atitude política voltada para satisfação de demandas exteriores à organização administrativa, diferentemente dos militares e burocratas?

Uma ligeira análise do quadro clerical brasileiro na primeira metade do XIX pode ajudar a esclarecer essa questão. De 1822 até o início do regresso conservador, o cenário político brasileiro foi marcado pela intensa presença de padres. O clero católico no período imperial, de maneira geral, possuía uma situação ambígua em relação ao Estado, em virtude do padre ser um funcionário público, remunerado pelo erário real, mas simultaneamente pertencer a uma organização paralela ao Estado: a Igreja. A formação desses líderes passava por sérias dificuldades no início do século XIX, por ter sido, até o século XVIII, responsabilidade dos Jesuítas. Com a expulsão dessa ordem religiosa do território brasileiro, os eclesiásticos passaram a ser mal formados, geralmente tendo costumes pouco acordes com a disciplina da Igreja. Muitos se envolviam em negócios, como fazendas escravistas, e participavam ativamente da política ${ }^{165}$.

Esses homens da Igreja possuíam, como recurso de poder, a educação acima da média somada ao prestígio religioso e, em alguns casos, ao poder econômico. O clero brasileiro também era fonte

${ }^{165}$ CARVALHO, José Murilo de. A construção da Ordem: a elite política imperial. Brasília: Editora da Universidade de Brasília, 1981. p. 142. 
permanente de conflitos potenciais com o Estado, em virtude da formação dessa categoria ter sido menos nacional e estadista. Além disso, a categoria possuía uma origem social mais democrática, e as menores condições de ascensão na carreira tornavam o grupo menos coeso do que os magistrados, que também se destacaram na política na primeira metade do século dezenove.

A atuação da maioria dos padres era muito próxima da população, tornando-os líderes populares em potencial, o que pode ser atestado pela participação em todos os movimentos de rebelião de 1789 a 1842, como as inconfidências mineira (1789) e baiana (1798) e a revolução praieira (1848). Esse radicalismo eclesiástico, entretanto, era mais político do que social, mantendo-se dentro dos limites do liberalismo ${ }^{166}$.

Percebe-se, por esse quadro, que o clero brasileiro, apesar de fazer parte da burocracia, possuía uma relativa distância em relação ao Estado, em virtude de participar de uma hierarquia paralela, a Igreja. Supõe-se que essa condição e a proximidade desses clérigos da população (e de suas demandas) fizeram com que esses homens, como parte do legislativo do Espírito Santo, se dedicassem a temas que fugiam aos assuntos estritamente ligados à estruturação político-administrativa do Estado.

Indícios disso seriam, por exemplo, o Padre João Clímaco de Alvarenga Rangel se interessando pela educação feminina e o Padre João Luiz da Fraga Loureiro atentando para a produtividade das sesmarias da província. Nesse sentido, apesar de os componentes da primeira legislatura da Assembleia Legislativa do Espírito Santo terem seguido suas carreiras antes do parlamento em três trajetórias diferentes - a militar, a eclesiástica e a burocrática - eles foram capacitados para a política. Essa capacitação era, sobretudo, usada para estabelecer um projeto político que objetivava transformar o Espírito Santo numa província que pudesse negociar com o Governo Geral e com grupos locais, visando à resolução de demandas regio-

${ }^{166}$ CARVALHO, 1981, p. 143-146. 
nais e à estruturação de uma ordem legal. O maior objetivo era garantir uma estabilidade política dentro dos moldes da monarquia constitucional, naquele momento, com um considerável grau de descentralização. 


\section{CONCLUSÕES}

Vinte homens e muitos traços semelhantes em suas biografias desenroladas no início do século dezenove. Ocupações políticas e profissões concentradas num reduzido conjunto de carreiras. Uma vez no parlamento, tentaram reestruturar política e administrativamente a província dentro dos moldes de novos tempos. Buscaram, simultaneamente, resolver problemas que há séculos dificultavam a vida do Espírito Santo. Ouviram os homens destacados da terra e, em alguns momentos, também receberam o clamor dos menos favorecidos. Um grupo de destaque que galgou os mais altos cargos em nível regional, graças não apenas a sua riqueza material, mas também às carreiras políticas e profissionais, que lhes forneceram treinamento, destaque e relacionamentos fundamentais para se elegerem, se manterem no poder por um tempo considerável e tentarem implementar um projeto político que atendesse às demandas do Espírito Santo. Uma elite regional que refletia, de acordo com modulações locais, a conjuntura atravessada pelo contexto nacional. Nesse sentido, tentava construir uma ordem regional que, simultaneamente, coadunasse com o contexto nacional favorável à descentralização do poder e atendesse às demandas locais.

Observou-se que, na primeira metade do oitocentos, o Espírito Santo possuía uma elite política capacitada, disposta e com apoio 
social para implementar reformas que transformassem a realidade local. O destino dessa transformação certamente estava sob a ótica de um grupo que, como grande parte das elites políticas, pretendia se perpetuar no poder, mas, ao mesmo tempo, objetivava uma melhoria das condições locais (um dos principais requisitos para se manter no poder, pois esse grupo, uma vez eleito, precisava de um mínimo de legitimidade). Como visto, essas melhorias tinham a meta de firmar uma estabilidade político-social na localidade, visando o reconhecimento da elite política pelos outros grandes da localidade, a prevenção de revoltas populares e escravas contra a ordem, e a precaução contra movimentos de outros setores de elite contra a ordem nacional.

No capítulo anterior, ficou bem claro que a elite política do Espírito Santo, consolidada na Assembleia Provincial, firmou-se como um reduto regional para onde as demandas locais fluíam. Prova disso foram as diversas petições enviadas por Câmaras Municipais, autoridades e até alforriados à Assembleia Legislativa para que esta resolvesse as questões dos remetentes.

Em relação ao governo central, a elite do Espírito Santo preocupou-se em deixar bem evidente sua adesão à ordem imperial instituída no pós-independência, apesar dos ventos de revoltas regionais que varriam o país na década de 1830. Em representação de 1837 ao Governo Central, a Assembleia do Espírito Santo assim se refere ao presidente de Província José Thomaz Nabuco de Araújo, nomeado pela Corte do Rio de Janeiro:

[...] Desde a época fatal em que este presidente recebeu as rédeas da administração, afetado da paixão com que desenvolveu a ardilosa cabala a seu favor na eleição de senador disseminando a intriga no meio dos habitantes da Província, já mais (sic) ela pode gozar daquele estado delicioso, que a paz e a união mútua dos cidadãos costumam inspirar nos povos de um país constitucional porque, tendo ele para conseguir essa eleição atropelado a honra, empregos, direitos e tranqüilidade dos cidadãos em seu desagrado por o não lisonjearem não hesitou mesmo em comprometer para 
com o Governo de V. M. I. o nome pacífico de uma província que tem dado sobejas provas de obediência e fidelidade à constituição do Império, figurando-a revoltada, e mesmo incitando a revolta para dar parto ao ódio, vingança contra os eleitos que o sufragarão ${ }^{167}$.

Por esse pequeno trecho pode-se apreender a "profissão de fé" política da elite do Espírito Santo. A submissão aos princípios constitucionais era apresentada pela Assembleia Legislativa como credencial para que o recurso da instituição fosse aceito nos redutos da elite nacional. Era contra um representante do Governo Central que a elite política do Espírito Santo recorria, tendo como suporte discursivo os princípios da unidade territorial e constitucionalidade. Apresentar-se como uma província em oposição aos ventos de revolta e separatismo que rondavam o Império era uma boa apresentação perante a Corte. Percebe-se que a elite do Espírito Santo, na primeira metade do XIX, possuía maturidade política suficiente para mover-se dentro das regras do jogo político Imperial.

Essa maturidade e capacitação, somadas ao capital político reunido no início do século XIX, permitiram a permanência desse grupo político até meados do oitocentos. O contexto em que a elite espírito-santense se consolidou é o dos anos logo após o Ato Adicional. o país vivia momentos em que as Assembleias Provinciais foram criadas com grande poder. No Espírito Santo, a elite política tinha diante de si uma grande oportunidade para resolver demandas da província. Entretanto, esses ventos de descentralização não durariam muito. Paralelamente à descentralização política, estouraram diversas revoltas provinciais pelo Império. A elite política nacional, inclusive em sua ala liberal, defensora da descentralização, entendia essas revoltas como resultado do Ato Adicional e temia que a situação chegasse ao ponto da anarquia e do esfacelamento do território nacional. Nesses termos, a elite política brasileira pendeu mais uma vez para a solução centralizadora. O próprio relator do Ato Adicional,

${ }^{167}$ ESTADO DO ESPÍRITO SANTO. Assembleia Legislativa. Representação enviada à S. M., o Imperador. 1837. 
o antigo liberal Bernardo Pereira de Vasconcelos, liderou a reação contra a descentralização da regência. Em 1837, o regente liberal Feijó renunciou diante da conjuntura nacional e um conservador foi eleito como novo regente. A nova Câmara, por sua vez, reformou as leis descentralizantes, reduziu o poder das Assembleias Provinciais e dos Juízes de Paz, formou uma justiça e uma polícia controladas pelo governo central. Na tentativa de evitar uma centralização extrema, os liberais proclamaram a maioridade prematura do Imperador, em 1840. Entretanto, os conservadores voltaram ao poder, em 1841, e completaram o regresso, restabelecendo o Conselho de Estado ${ }^{168}$.

o período do Segundo Reinado foi marcado pela centralização política e administrativa. A centralização política era representada pelo poder moderador, por meio do qual o Imperador podia nomear e demitir livremente os ministros, pelo Senado vitalício e pela nomeação dos presidentes de província pelo Ministro do Império, que também nomeava os bispos, os párocos e os delegados de polícia. Administrativamente, toda justiça foi concentrada no Ministro da Justiça. O Ministro da Justiça podia nomear e demitir em todo território do Império, desde o Ministro do Supremo Tribunal de Justiça até o guarda da prisão. o Juiz de Paz que no período regencial era eleito com grandes poderes perdeu boa parte de suas funções para os delegados de polícia ${ }^{169}$.

Sendo assim, a conjuntura que a elite política do Espírito Santo enfrentou, a partir de 1837, era avessa à de 1835. Mesmo assim, essa elite conseguiu, graças ao treinamento e ao capital político acumulado, manter-se no poder por mais tempo. Alguns se preservaram individualmente por um período bem maior, sendo o caso mais emblemático o de José Francisco de Andrade e Almeida Monjardim, que ficou na política provincial até o final do século dezenove.

No entanto, nem todos ficariam no poder após a primeira legislatura. Dentre eles, há um exemplo notável. Um político que, no

\footnotetext{
${ }^{168}$ CARVALHO, José Murilo de. Pontos e bordados: escritos de história política. Belo Horizonte: UFMG, 1998. p. 167.

${ }^{169}$ CARVALHO, 1998, p. 169.
} 
primeiro terço do século XIX, destacou-se na política local e galgou espaço até no cenário nacional. O Padre João Clímaco de Alvarenga Rangel foi o primeiro presidente da Assembleia Legislativa do Espírito Santo. A última vez que esse Padre ocupou um cargo político foi na legislatura da Assembleia do Espírito Santo de 1840 a 1841. Depois, João Clímaco nunca mais foi visto na cena política institucional, dedicando-se ao ofício da advocacia, à escrita de poemas e ao sacerdócio.

Teria esse homem, outrora atuante na política local, como demonstram as atas da Assembleia Legislativa, caído no esquecimento ou desagravo da população do Espírito Santo? Não existem indícios para isso. O que se tem é um apontamento feito por seu biógrafo, Afonso Cláudio.

Para Afonso Cláudio, João Clímaco havia, por algum motivo, se desgostado da vida pública, como fica apresentado nas linhas abaixo:

[...] Na província, o Padre Clímaco foi professor de filosofia, diretor de Liceu, deputado e vice-presidente, havendo sido eleito Deputado Geral em 1833, quando ainda estudante do curso jurídico; desses cargos retirou-se enfastiado à vida privada, abandonando de vez a política, em que, aliás, gastara os melhores anos do seu vigor intelectual [...] seus versos são reproduções do que lhe vai pelo interior d'alma, ora conturbado pelo misticismo religioso, como Domingos de Caldas, ora ressentido pelas perfídias e cavilações que o tinham chocado a senda política. [...] A política do segundo reinado desviou Clímaco dos seus propósitos literários para as lides eleitorais; parece que, porém, abandonou-a sem saudades, amargurado e... emendado, porque não reincidiu no desvario ${ }^{170}$.

Pelo relato de Afonso Cláudio, o introspectivo João Clímaco optou por não militar na nova conjuntura pós-regresso conservador. $\mathrm{O}$ deputado que tanto saudara os novos tempos prometidos pelo Ato Adicional, em que pareceria possível a concretização de

${ }^{170}$ CLAÚDIO, Afonso. História da Literatura Espírito Santense. Rio de Janeiro: Biblioteca reprográfica xerox, 1981. p. 113-115. 
um projeto político para o Espírito Santo dentro da ordem constitucional nacional, agora via esse sonho se desvanecer. Os demais deputados, entretanto, tiveram uma posição mais pragmática. Dentro da nova ordem mais centralizada, tentariam continuar a tocar os negócios da Província, até que essa geração política deixasse o cenário provincial, no início da década de 1860, tendo restado dela apenas alguns resquícios até o final do século XIX.

João Clímaco, diferentemente, preferiu deixar seu legado fora da carreira política, como demonstrado abaixo em seu testamento político, na forma de poema:

\author{
[...] Sempre aos crimes austero e inexorável, \\ Jamais com avaros peitos pactuei; \\ Poder, riquezas, sob os pés calquei, \\ Nada pode vencer meu peito estável. \\ Em prol da pátria mãe sempre incansável \\ Glória, bens, honra e nome procurei; \\ Mas qual o prêmio que daí lucrei? \\ Abandono, desprezo, ódio execrável! \\ Que lição tão fatal de heroísmo!... \\ E devo ainda fraternais ofícios \\ Solicitar, qual favor, ao despotismo? \\ Não... à pátria rendi meus sacrifícios, \\ Virtudes? Sentou-se em seu lugar o egoísmo, \\ Pátria, lares, adeus! Adeus patrícios ${ }^{171}$.
}

Para os patrícios da elite política do Espírito Santo que ficavam, todavia, era hora da rearticulação do projeto político regional, tendo como referência um treinamento granjeado em trajetórias político profissionais desenvolvidas desde o início do oitocentos.

${ }^{171}$ CLAÚDIO, 1981, p. 115. 


\section{REFERÊNCIAS}

\section{FONTES PRIMÁRIAS}

ARQUIVO DA ASSEMBLEIA LEGISLATIVA DO ESPÍRITO SANTO. Arrogo de Vicência Maria à Assembleia Legislativa Provincial do Espírito Santo. 1835.

ARQUIVO DA ASSEMBLEIA LEGISLATIVA DO ESPÍRITO SANTO. Ata de apuração dos votos para conselho geral de província do Espírito Santo. 1829.

ARQUIVO DA ASSEMBLEIA LEGISLATIVA DO ESPÍRITO SANTO. Ata da apuração dos votos para Deputado Provincial dos colégios eleitorais de Vitória e Vila de Benevente. 1834.

ARQUIVO DA ASSEMBLEIA LEGISLATIVA DO ESPÍRITO SANTO. Relatório de Manoel Pires da Silva Pontes ao Conselho Geral. 1833.

ARQUIVO DA ASSEMBLEIA LEGISLATIVA DO ESPÍRITO SANTO. Representação da Assembleia Legislativa do Espírito Santo à Assembleia Geral. 30/03/1835. 
ESTADO DO ESPÍRITO SANTO. Assembleia Legislativa (1835-1837). Representação enviada à S. M., o Imperador. Vitória, 1837.

BIBLIOTECA NACIONAL. Documentos Biográficos. Documento C-0114, 040. Documentos referentes a Manoel da Siqueira e Sá. 1830-1855.

BIBLIOTECA NACIONAL. Documento C 694, 11. 1823. Luiz da Silva Alves de Azambuja Suzano, Petição. 1823.

BIBLIOTECA NACIONAL. Documento C-0694, 011, nํ 002. 1816-1817.

Requerimento encaminhado ao ministério do império solicitando nomeação para secretário do governo da capitania do Espírito Santo.

BIBLIOTECA NACIONAL. Documentos Biográficos. Documento C-0837, 008. Requerimento ao ministério do Império. José de Barros Pimentel. 1824-1828.

BIBLIOTECA NACIONAL. Seção de Obras Raras. Documento C-0355, 006. Requerimento encaminhado ao ministério do império solicitando a mercê da Ordem Cristo. 1823-1825.

BIBLIOTECA NACIONAL. Documento C-0032, 009. nº . 1. Requerimento encaminhado ao Ministério do Império solicitando aposentadoria. 1830-1840.

ESTADO DO ESPÍRITO SANTO. Assembleia Legislativa. Ata. 1835-1837.

ESTADO DO ESPÍRITO SANTO. Assembleia Legislativa. Representação enviada à S. M., O Imperador. 1837.

\section{FONTES SECUNDÁRIAS}

DAEMON, Basílio. História, descoberta e estatística do Espírito Santo. 
Vitória: Tipografia do Espírito Santo, 1879.

MARQUES, Cezar Augusto. Dicionário Histórico, Geográfico e Estatístico da Província do Espírito Santo. Rio de Janeiro: Tipografia Nacional, 1878.

PENA, Misael Ferreira. História da Província do Espírito Santo. Rio de Janeiro: Tipografia de Moreira, 1878.

PEREIRA, Amâncio. Traços biográficos. Vitória: Papelaria e Tipografia de A. Moreira Dantas, 1897.

PEREIRA, Amâncio. Almanak do Estado do Espírito Santo. Vitória: A. Moreira Dantas, 1899.

\section{LIVROS}

ALMOND, Gabriel A.; POWELL, G. Bingham. Uma teoria política comparada. Rio de Janeiro: Zahar Editores, 1972.

BICHARA, Terezinha Tristão. História do poder legislativo do Espírito Santo 1835-1889. Vitória: Leoprint, 1984.

BONICENHA, Walace. Devoção e caridade: As irmandades religiosas na cidade de Vitória. Vitória: Editora Multiplicidade, 2004.

BOURDIEU, Pierre. O Poder Simbólico. Rio de Janeiro: Bertrand Brasil, 2006.

CLAÚDIO, Afonso. História da Literatura Espírito Santense. Rio de Janeiro: Biblioteca reprográfica xerox, 1981.

CARVALHO, José Murilo de. A construção da Ordem: a elite política imperial. Brasília: Editora da Universidade de Brasília, 1981. 
. Cidadania no Brasil: o longo caminho. 6. ed. Rio de Janeiro: Civilização Brasileira, 2004.

_-_-_-_. Pontos e bordados: escritos de história política. Belo Horizonte: UFMG, 1998.

CLÁUDIO, Afonso. Insurreição do Queimado. Vitória: Editora da Fundação Ceciliano Abel de Almeida, 1979. p. 79.

COSTA, Pedro Pereira da Silva. José Bonifácio. Rio de Janeiro: Editora Três, 1974.

CUNHA, Manuela Carneiro. Antropologia do Brasil: Mito, história, etnicidade. São Paulo, 1985.

DOLHNIKOLF, Miriam (Org.). José Bonifácio de Andrada e Silva. São Paulo: Companhia das Letras, 2000.

ELTON, Elmo. Poetas do Espírito Santo. Vitória: 1982.

FERREIRA, Gabriela Nunes. Centralização e Descentralização no Império: O Debate entre Tavares Bastos e Visconde do Uruguai. São Paulo: Editora 34, 1999.

FLORETINO, Manolo. Em costas negras. São Paulo: Companhia das Letras, 1997.

GIL, Antônio Carlos Amador. Projetos de Estado no alvorecer do Império. Vitória: Instituto Histórico e Geográfico do Espírito Santo, 2002.

GINSBURG, Carlo et al. A micro história e outros ensaios. Lisboa: Difel, 1991. 
HEIZ, Flávio M. (Org.). Por outra história das elites. Rio de Janeiro: Editora FGV, 2006.

LOUSADA, Maria Alexandre. Espaços de sociabilidade em Lisboa. Lisboa: Dissertação de Doutorado em Geografia Humana apresentada à Faculdade de Letras da Universidade de Lisboa, 1995.

LINHARES, Maria Yedda (Org.). História Geral do Brasil. 4. ed. Rio de Janeiro: Campus, 1990.

NEVES, Lúcia Maria Bastos P.; MOREL, Marco; FERREIRA, Tânia Maria Bessone da C. (Org.). História e imprensa: representações culturais e práticas de poder. Rio de Janeiro: Faperj, 2006.

MELO, Olímpio de. Ordens militares portuguesas e outras condecorações. Imprensa Nacional de Lisboa. 1922.

MONJARDIM, Leonardo Passos. História Política da família Monjardim. Vitória: Lei Rubem Braga, 2003.

NOVAES, Maria Stella de. História do Espírito Santo. Vitória: FEES, [19-].

OLIVEIRA, José Teixeira de. História do Estado do Espírito Santo. Rio de Janeiro: Oficinas do serviço gráfico do IBGE, 1975.

POLIANO, Luiz Marques. Ordens Honoríficas do Brasil. Rio de Janeiro: Imprensa Nacional. 1943.

PRADO, Maria Emília (Org.). O Estado como vocação. Rio de Janeiro: Access, 1999.

REMOND, René. Por uma história Política. Rio de Janeiro: UFRJ/FGV, 1996. 
SANTOS, Estilaque Ferreira dos. A monarquia no Brasil: o pensamento político da independência. Vitória: Edufes/CEG Publicações, 1999.

SOUZA, Iara Lis Carvalho. Pátria coroada: O Brasil como corpo político autônomo 1780-1831. São Paulo: Fundação Editora da UNESP, 1999.

SCHWAB, Affonso. A irmandade e a Santa Casa da Misericórdia do Espírito Santo. Vitória: Arquivo Público Estadual. 1979.

SCHWACZ, Lilia Moritz. As barbas do Imperador: D. Pedro II, um imperador nos trópicos. São Paulo: Companhia das Letras, 2006.

\section{TESES}

CAMPOS, Adriana Pereira. Nas barras dos tribunais: direito e escravidão no Espírito Santo do Século XIX. 276 f. Tese (Doutorado em História) _ Programa de Pós-Graduação em História Social, Universidade Federal do Rio de Janeiro, Rio de Janeiro, 2003.

\section{REVISTAS}

LEAL, J. E. Franklin. Economia Colonial Capixaba. Cuca: Cultura Capixaba. Vitória, n. 0, fev. 1977.

\section{SITES}

www.bibvirt.futuro.usp.br www.estacaocapixaba.com.br www.irdeb.ba.gov.br www.poetas.capixabas.com.br 